630.7

Il6b

no. 765

cop. 8 
NOTICE: Return or renew all Library Materials! The Minimum Fee for each Lost Book is $\$ 50.00$.

The person charging this material is responsible for its return to the library from which it was withdrawn on or before the Latest Date stamped below.

Theft, mutilation, and underlining of books are reasons for discipliTo renew call Telephone

UNIVERSITY OF ILLINOIS LIBRARY AT URBANA-CHAMPAIGN

UNIVERSITY

ILLINOIS LIBR

AT URBANA.CHA

AGRICULTU

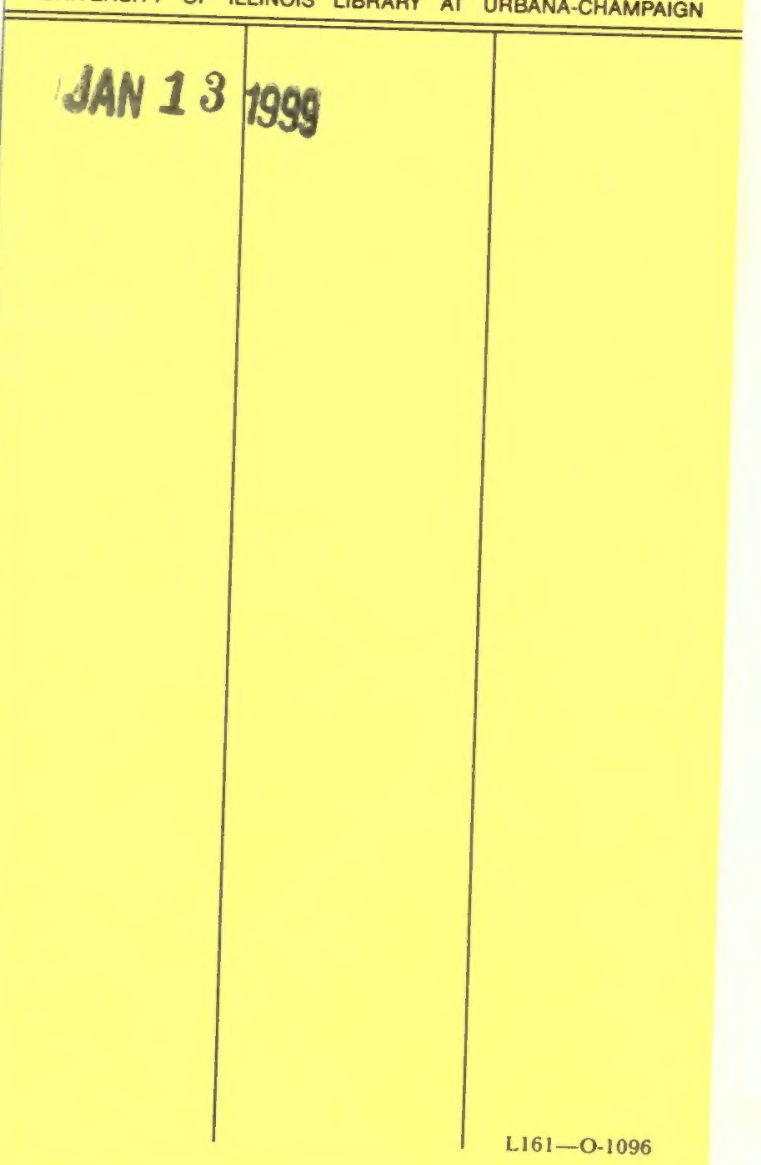




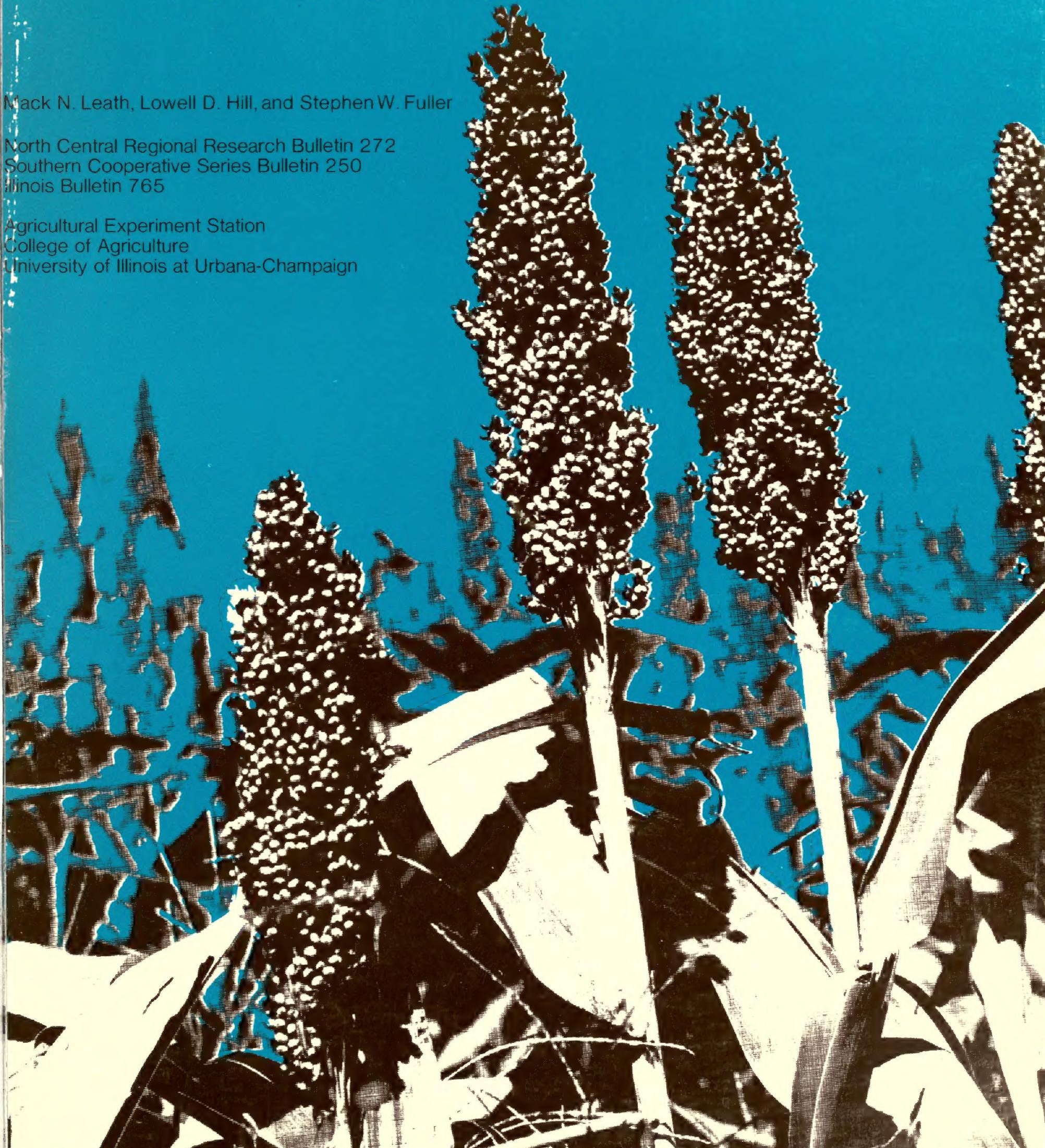




\begin{abstract}
The marketing of sorghum in the U.S. involves complex interregional grain movements. Moving the crop from its highly concentrated production region to points where it is used or exported requires a large transportation capacity. To provide a basis for policy and investment decisions, detailed information on sorghum movements during 1977 was collected from 3,500 grain merchandising, processing, and exporting firms in 41 states. Survey data on receipts and shipments for each state or substate area were expanded to represent total volumes for those areas and were verified by comparison with information from secondary sources. The data, which represent the most comprehensive and accurate information available on sorghum movements, are presented and summarized in this bulletin.
\end{abstract}

Keywords: Grain flows, grain shipping, grain transportation, interregional analysis, sorghum, sorghum marketing. 


\section{Sorghum Movements - in the United States

Mack N. Leath, Agricultural Economist, Economics and Statistics Service, U. S. Department of Agriculture

Lowell D. Hill, L. J. Norton Professor of Marketing, Department of Agricultural Economics, University of Illinois at Urbana-Champaign

Stephen W. Fuller, Associate Professor, Department of Agricultural Economics, Texas A\&M University

North Central Regional Research Bulletin 272

Southern Cooperative Series 250

Illinois Bulletin 765
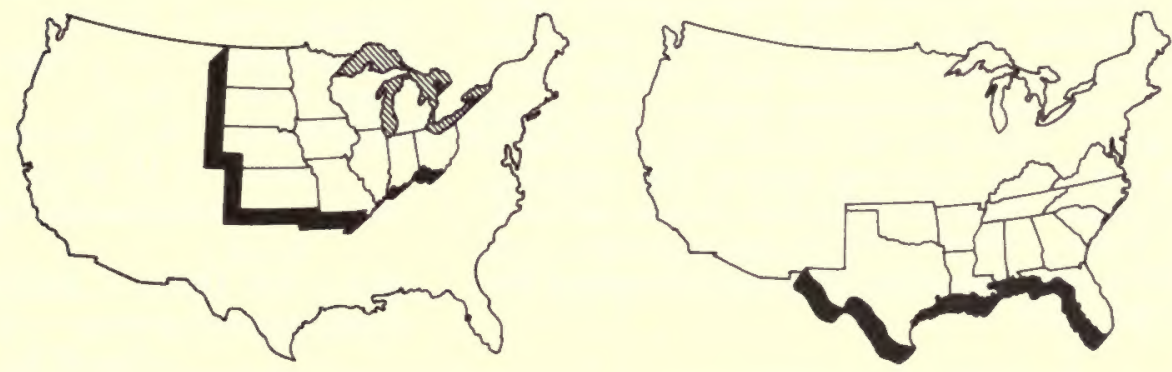

Agricultural Experiment Stations of Alabama, Arkansas, California, Georgia, Idaho, Illinois, Indiana, lowa, Kansas, Kentucky, Louisiana, Michigan, Minnesota, Mississippi, Missouri, Montana, Nebraska, North Dakota, Ohio, Oklahoma, Oregon, South Dakota, Tennessee, Texas, Wisconsin, and the United States Department of Agriculture cooperating.

The participating agricultural experiment stations and government agencies provide equal opportunities in programs and employment.

January 1981 
This publication is sponsored by the Agricultural Experiment Stations of the following states, by the Science and Education Administration - Cooperative Research (SEA-CR), U.S. Department of Agriculture (USDA), and by the Economics and Statistics Service (ESS), USDA.

$\begin{array}{ll}\begin{array}{l}\text { Participating } \\ \text { state }\end{array} & \begin{array}{l}\text { Experiment station } \\ \text { director }\end{array} \\ \text { Alabama } & \text { G. A. Buchanan } \\ \text { Arkansas } & \text { L. O. Warren } \\ \text { California } & \text { J. B. Kendrick, Jr. } \\ \text { Georgia } & \text { W. P. Flatt } \\ \text { Idaho } & \text { R. J. Miller } \\ \text { Illinois } & \text { R. G. Cragle } \\ \text { Indiana } & \text { B. R. Baumgardt } \\ \text { Iowa } & \text { L. R. Kolmer } \\ \text { Kansas } & \text { F. W. Smith } \\ \text { Kentucky } & \text { C. E. Barnhart } \\ \text { Louisiana } & \text { D. Chambers } \\ \text { Michigan } & \text { S. H. Wittwer } \\ \text { Minnesota } & \text { R. J. Sauer } \\ \text { Mississippi } & \text { R. R. Foil } \\ \text { Missouri } & \text { A. M. Lennon } \\ \text { Montana } & \text { J. R. Welsh } \\ \text { Nebraska } & \text { R. G. Arnold } \\ \text { North Dakota } & \text { H. R. Lund } \\ \text { Ohio } & \text { R. M. Kottman } \\ \text { Oklahoma } & \text { C. B. Browning } \\ \text { Oregon } & \text { J. R. Davis } \\ \text { South Dakota } & \text { R. A. Moore } \\ \text { Tennessee } & \text { D. M. Gossett } \\ \text { Texas } & \text { N. P. Clarke } \\ \text { Wisconsin } & \text { L. M. Walsh } \\ & \end{array}$

This publication reports the results of research conducted by three regional technical committees: Southern Regional Committee S-115 on Alternative Structures for Increasing Efficiency in Intra- and Inter-regional Grain Marketing Systems; North Central Regional Committee NC-137 on Evaluation of Alternative Rural Freight Transportation, Storage, and Distribution Systems, and North Central Regional Committee NC-139 on Economic Analysis of the U.S. Grain Exporting System. The following state Agricultural Experiment Station representatives, Tennessee Valley Authority (TVA) staff members, and U.S. Department of Agriculture personnel comprised the technical committees.

\section{SOUTHERN REGIONAL COMMITTEE S-115}

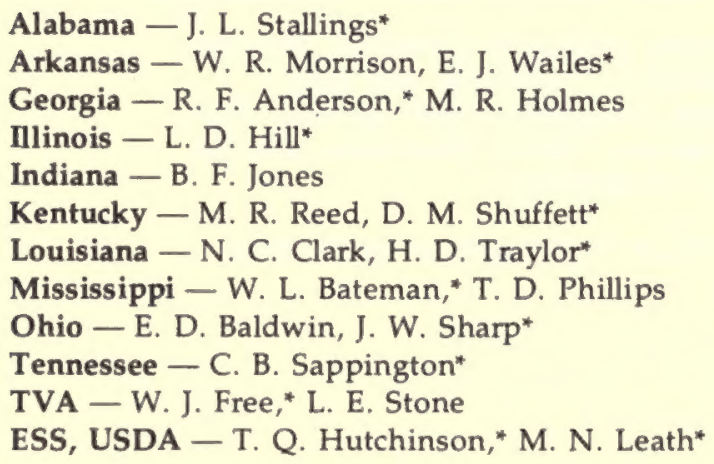

SEA - CR, USDA - L. C. Halvorson

Administrative Adviser - T. J. Whatley (Tennessee)

NORTH CENTRAL REGIONAL COMMITTEE NC-137

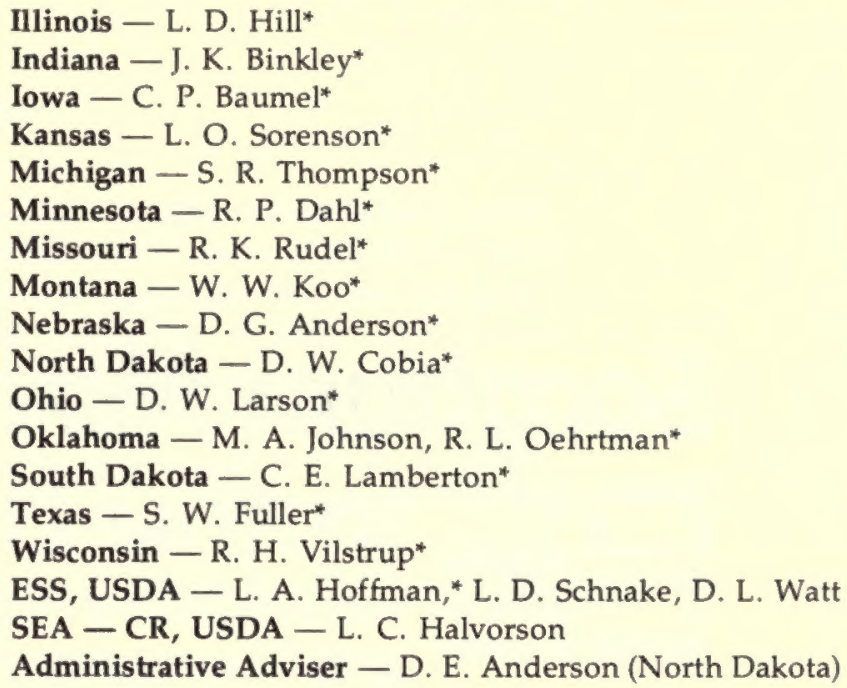

NOR'TH CENTRAL REGIONAL COMMITTEE NC-139

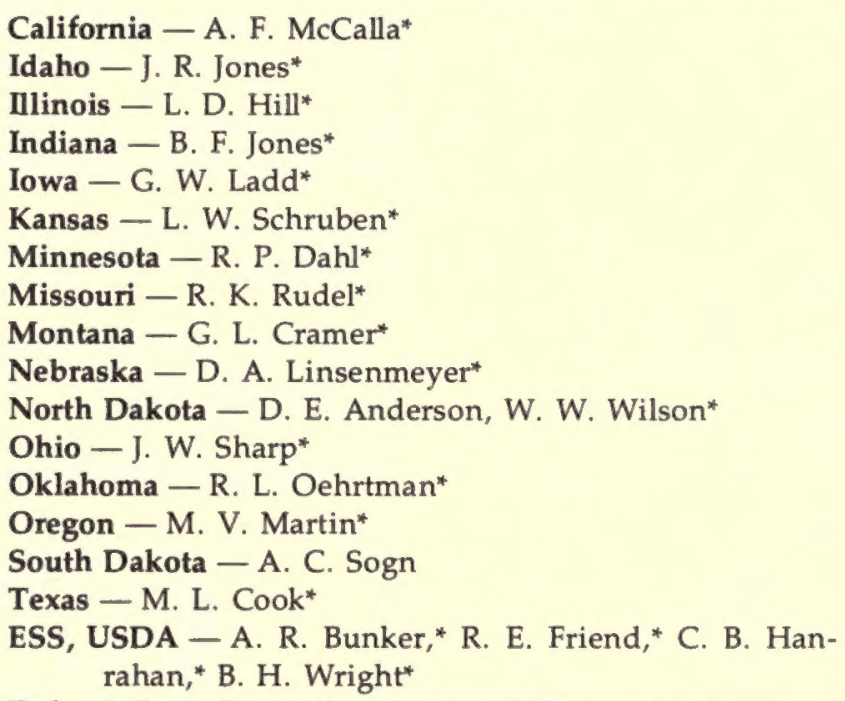

Federal Grain Inspection Service, USDA - F. F. Niernberger

SEA - CR, USDA - L. C. Halvorson

Administrative Adviser - H. J. Schweitzer (Illinois)

The following state Agricultural Experiment Station personnel also cooperated in the research:

$\begin{array}{ll}\text { Arizona - T. F. Archer } & \text { Pennsylvania - S. K. Abshire } \\ \text { Colorado - W. T. Spencer } & \\ \text { Connecticut - S. K. Seaver } & \text { South Carolina - S. E. Moore } \\ \text { Florida - J. K. Dow } & \text { Utah - R. H. Anderson } \\ \text { Maine - D. D. Harlan } & \text { Vermont - N. T. Power } \\ \text { Maryland - J. L. Crothers } & \text { Virginia - D. E. Kenyon } \\ \text { New York - M. E. Brunk } & \text { Washington - K. L. Casavant } \\ \text { North Carolina - T. E. } & \text { Wyoming - J. S. St. Clair } \\ \quad \text { Nichols } & \end{array}$

* Voting member and project leader for the participating organization. 


\section{Preface}

The research reported in this bulletin is the first effort ever made to survey grain shippers and receivers nationwide; it is the most comprehensive study of grain movements ever conducted. Members of the technical committees, including representatives of Agricultural Experiment Stations in 25 states, assisted in conducting an industry survey to collect flow data for wheat, corn, soybeans, sorghum, oats, barley, and rye. In addition, surveys were conducted in 16 other states through contracts with 15 universities located in those states. The industry surveys were coordinated by Lowell D. Hill, Department of Agricultural Economics, University of Illinois at Urbana-Champaign. The data were tabulated and summarized under the supervision of Mack N. Leath, Economics and Statistics Service, U.S. Department of Agriculture. The success of this research project is due to the cooperation of thousands of grain marketing firms and the efforts of researchers in the many participating states.

The research was funded in part through contract DACW 72-78-C-0005 with the Institute of Water Resources, U.S. Army Corps of Engineers. Supplemental support was provided by the Federal Railroad Administration of the U.S. Department of Transportation, the Maritime Administration of the U.S. Department of Commerce, and the St. Lawrence Seaway Development Corporation. Administration of grant funds was coordinated by Lowell D. Hill, University of Illinois at Urbana-Champaign.

\section{Contents}

Introduction $\ldots \ldots \ldots \ldots \ldots \ldots \ldots \ldots \ldots \ldots \ldots \ldots \ldots \ldots \ldots \ldots \ldots$

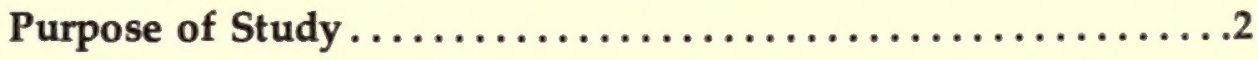

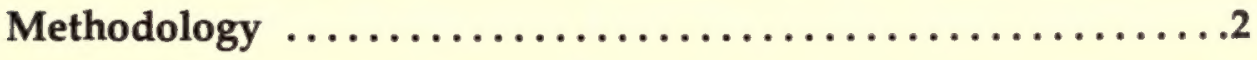

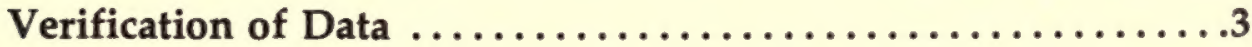

Overview of Movements ........................

Receipts and Shipments by Area $\ldots \ldots \ldots \ldots \ldots \ldots \ldots \ldots \ldots$ 
. 


\section{Tables}

1. Sorghum Supply and Distribution in the United States for Marketing Years from 1970-71

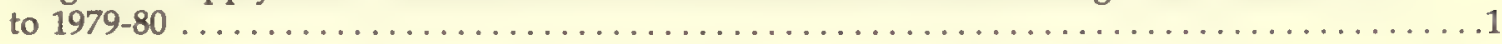

2. Production, Farm Use, and Sales of Sorghum by State for the 1977 Crop . . . . . . . . . . . 3

3. Export Regions, Port Areas, and the Ports Included in Each Area . . . . . . . . . . . . . . . 5

4. Comparison of 1977 Sorghum Receipts, Shipments, and Inspections for Export

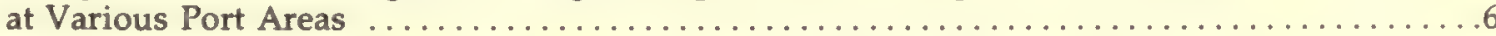

5. Comparison of 1977 Waterway Movements of Sorghum in the U.S. as Reported by Survey Respondents and the U.S. Army Corps of Engineers ...................

6. Comparison of 1977 Rail Movements of Sorghum as Reported by Survey Respondents and as Estimated from the 1 Percent Waybill Sample in Selected States ............... 7

7. 1977 Intrastate Shipments of Sorghum for Each State and Mode of Transportation . . . . . . 8

8. 1977 Interstate Shipments of Sorghum for Each State and Mode of Transportation . . . . . . .9

9. 1977 Interstate Receipts of Sorghum for Each State and Mode of Transportation . . . . . . . . 10

10. 1977 Movements of Sorghum to Points of Export for Each Originating State

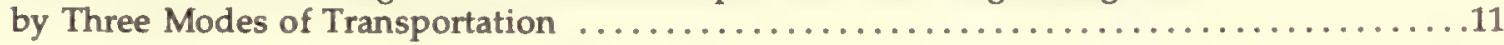

11. 1977 Receipts of Sorghum at Port Areas by Each Mode of Transportation .............12

12. 1977 Exports of U.S. Sorghum by Export Region and Destination . . . . . . . . . . . 13 13-

103. Sorghum Receipts and Shipments by State and Substate Areas . . . . . . . . . . . 14

104-

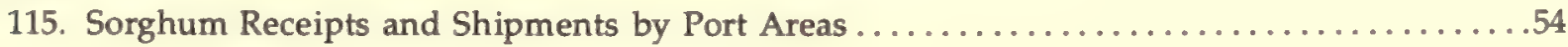

\section{Figures}

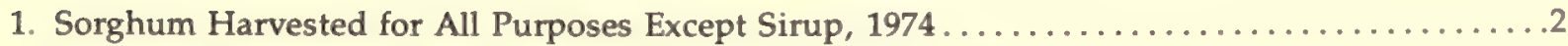

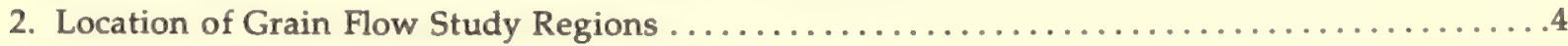

3. Patterns of Sorghum Flow to Domestic Destinations, $1977 \ldots \ldots \ldots \ldots \ldots \ldots \ldots$

4. Patterns of Sorghum Flow to Port Areas, 1977 . . . . . . . . . . . . . . . . . . . . . 11

5. Proportion of 1977 Sorghum Movements to Export Regions from Each Originating State .....12 



\title{
Sorghum Movements in the United States
}

\author{
Interregional Flow Patterns and Transportation Requirements in 1977
}

\section{INTRODUCTION}

Information about the origin and destination of grain produced in the United States and about the modes of transportation used to convey it is important for many policy and investment decisions. Although data on the quantities of grains shipped abroad from each port are available and statistics on the amount of grain shipped on the inland waterways are published annually, little information is available that can be used to match origins with destinations and to identify the mode of transportation used.

Through personal interviews with over 3,500 grain merchandisers, processors, and exporters throughout the United States, data on origins, destinations, and transport modes have now been assembled for corn, wheat, soybeans, sorghum, oats, barley, and rye. This publication summarizes the data for sorghum. Other publications in this series provide similar information for the other grains.

Sorghum is the second most important feed grain produced in the United States. Annual production has gen- erally exceeded 700 million bushels in recent years (Table 1). During the 1970s the amount of sorghum used for human consumption declined from 3 million bushels to 1 million bushels, and the quantity used in alcoholic beverage production averaged about three million bushels annually. The amount used for seed is almost totally a function of the acreage planted; it has accounted for about 2 million bushels annually. The major domestic use of sorghum is for livestock feed. The usage for feed varies greatly from year to year in response to changes in the relative price and supply of sorghum as compared to other feed grains. The annual usage for feed generally exceeded 500 million bushels during the 1970s. The most dramatic growth in the demand for sorghum has been in the export markets. Export shipments of sorghum increased from 123 million bushels in 1971-72 to an estimated 350 million bushels in 1979-80.

Sorghum requires a large volume of transportation because it is grown in a highly concentrated production area and because the very large export demand is focused on only a few ports on the Gulf of Mexico. The production of sorghum is concentrated in the Southern

Table 1. Sorghum Supply and Distribution in the United States for Marketing Years from 1970-71 to 1979-80

\begin{tabular}{|c|c|c|c|c|c|c|c|c|c|}
\hline \multirow[b]{2}{*}{$\begin{array}{c}\text { Marketing } \\
\text { year }\end{array}$} & \multicolumn{3}{|c|}{ Supply } & \multicolumn{6}{|c|}{ Disappearance } \\
\hline & $\begin{array}{l}\text { Begin- } \\
\text { ning } \\
\text { stocks }\end{array}$ & $\begin{array}{l}\text { Produc- } \\
\text { tion }\end{array}$ & Total & Food & $\begin{array}{c}\text { Alc. } \\
\text { bever- } \\
\text { ages }\end{array}$ & Seed & $\begin{array}{l}\text { Feed } \\
\text { and re- } \\
\text { sidual }\end{array}$ & Exports & Total \\
\hline & \multicolumn{9}{|c|}{ millions of bushels } \\
\hline $1970-71$ & 244 & 683 & 927 & 3 & 4 & 3 & 683 & 144 & 837 \\
\hline $1971-72$ & 90 & 868 & 958 & 2 & 5 & 2 & 685 & 123 & 816 \\
\hline $1972-73$ & 142 & 801 & 943 & 2 & 2 & 2 & 652 & 212 & 870 \\
\hline $1973-74$ & 73 & 923 & 996 & 2 & 3 & 2 & 694 & 234 & 935 \\
\hline $1974-75$ & 61 & 623 & 684 & 1 & 3 & 2 & 431 & 212 & 649 \\
\hline $1975-76$ & 35 & 753 & 788 & 1 & 3 & 2 & 502 & 229 & 737 \\
\hline $1976-77$ & 51 & 720 & 771 & 1 & 3 & 2 & 428 & 246 & 680 \\
\hline $1977-78$ & 91 & 793 & 884 & 1 & 4 & 2 & 473 & 213 & 693 \\
\hline $1978-79$ & 191 & 748 & 939 & 1 & 3 & 2 & 566 & 207 & 779 \\
\hline $1979-80^{b}$ & 160 & 814 & 974 & 1 & 4 & 2 & 496 & 325 & 828 \\
\hline
\end{tabular}

Beginning October 1.

bstimated as of October, 1980.

Source: Feed Situation, Economics and Statistics Service, U.S. Department of Agriculture (various issues). 
Figure 1. Sorghum harvested for all purposes except sirup, 1974.

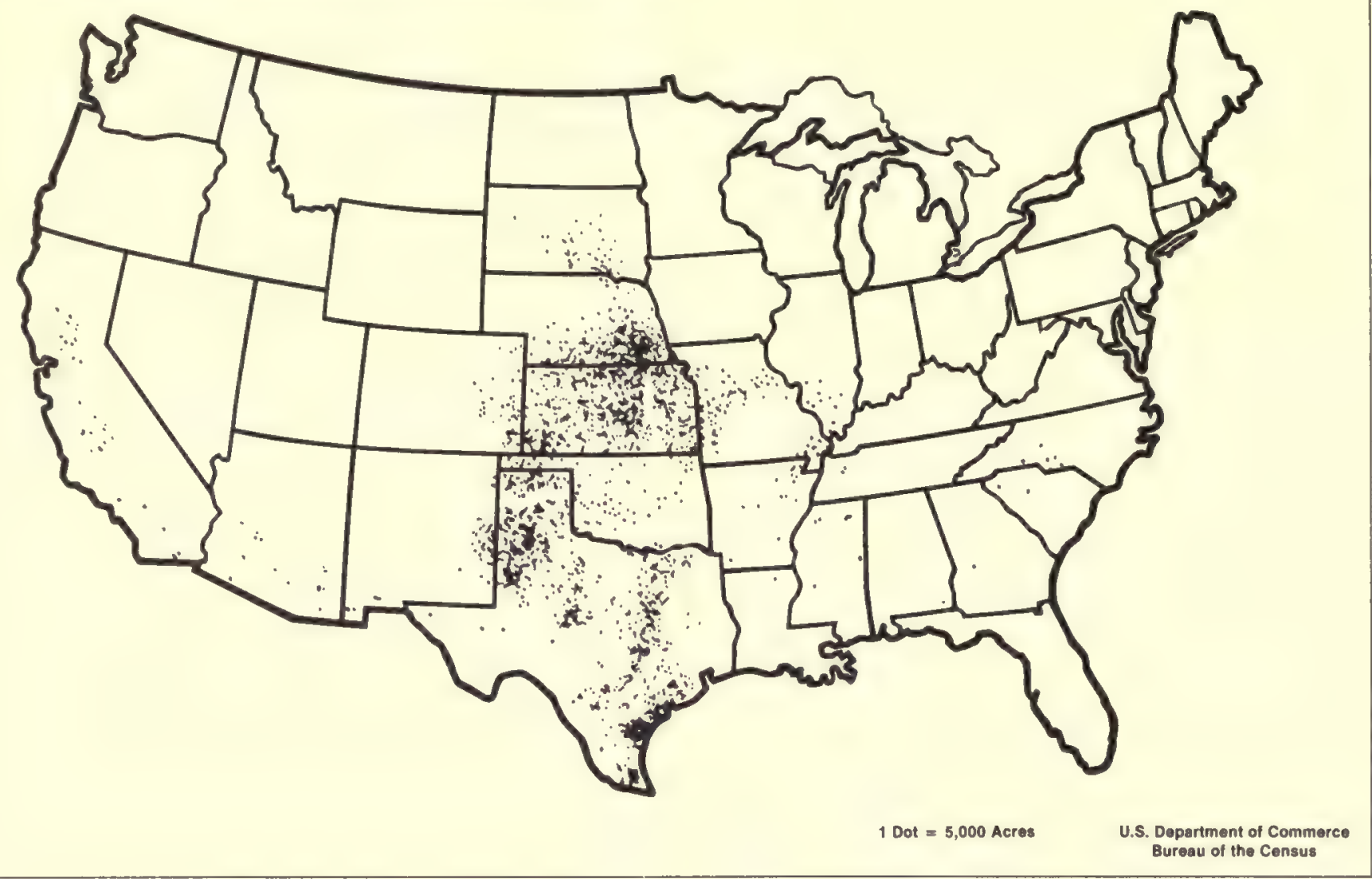

Great Plains where rainfall is usually inadequate for corn and soybean production (Figure 1). The area of concentrated production extends from southern Nebraska to the Texas gulf coast. The leading states in sorghum production are Kansas, Missouri, Nebraska, and Texas (Table 2). In 1977 these four states produced 688 million bushels of sorghum, 87 percent of the total U.S. production. About 32 percent of all the sorghum produced in the nation was used for feed and seed on the farms where it was produced, and about 62 percent was sold from farms.

\section{PURPOSE OF STUDY}

Analysis of grain flow patterns can reveal the geographical nature of grain markets and the type of transportation services required by the grain industry. This information is useful to grain firms in identifying additional marketing opportunities and in making decisions about where to locate new handling, storage, and processing facilities. Of equal importance is the value of this information to those who set federal and state transportation policies. The formulation of rational grain transportation policies depends upon knowledge of existing grain flows and associated transportation modes. In many situations, firms or public agencies make deci- sions affecting the production, storage, and transportation of grain without adequate information about grain distribution patterns and the demands that those decisions will place on the various transportation modes. The objectives of this study were:

1. To determine the volume of sorghum moving between various origins and destinations

2. To determine the extent to which the various transportation modes are employed in the movement of sorghum in the U.S.

\section{METHODOLOGY}

For the purposes of this study, the United States was divided into 132 numbered regions and 31 ports, as shown in Figure 2. Data from the 31 ports were aggregated into 13 port areas located in four major export regions. The specific ports included in each port area are listed with their identifying numbers in Table 3. Sorghum flow data were collected for the 1977 calendar year primarily through personal interviews with representatives of grain handling, storage, and processing firms in 41 states. The firms from which data were obtained included country elevators, inland terminal elevators, river terminal elevators, feed manufacturers, export elevators, commercial feedlots, and processing 
firms. A representative from each state's Agricultural Experiment Station was responsible for drawing the sample and conducting the interviews.

The sampling of inland grain elevators in the particular state was carried out by listing the elevators in descending order of storage capacity. Starting with the largest, elevators were added to the sample until the total of their storage capacities was equal to at least 25 percent of the inland elevator storage capacity in that state. Not less than 10 percent of the remaining elevators were then selected at random. For river elevators the procedure was simpler: a minimum of 50 percent of the elevators were selected by random sampling.

Feed manufacturing firms in each state were arrayed on the basis of their production capacity. Starting with the largest, feed firms on the list were added to the sample until the total of their production capacities equalled or exceeded 10 percent of the total feed manufacturing capacity in the state. Ten percent more of the remaining firms were then selected at random and included in the sample. All exporters and processors were included in the interviews.* Data based on random samples were expanded in proportion to the sampling rate to convert the data into estimates for the entire region or state.

The same types of information were gathered from all the grain handlers and processors interviewed. Each firm was asked to identify the volume of grain that it received from each region and the volume that moved by each mode of transportation. The firms were also asked to identify each region or port area for which their shipments were destined and the quantity shipped by each mode.

Experiment Station representatives verified the accuracy of the data collected, expanded the sample data to state totals, and delivered the summary data for each grain and for every substate region to the U.S. Department of Agriculture for processing. As receivers' and shippers' data were tabulated, the Experiment Station representative in each state checked any discrepancies to identify potential data errors and to arrive at a single number for each origin-destination pair. Insofar as possible, the state representatives checked data to ascertain that they were consistent and logical.

\section{VERIFICATION OF DATA}

The accuracy of the data on the volume of sorghum shipped between the various origins and destinations by each mode of transportation was verified by several direct and indirect comparisons with data from other sources. One indirect check was made by adding receipts to the surplus or deficit to obtain the supply

\footnotetext{
" Only one major processor did not provide data for the study. Data on receipts by that firm were estimated from information furnished by shippers.

† The surplus or deficit for each state was calculated by adding the 1977 production to the stocks in all positions as of January 1, 1977 , then subtracting the amount used for livestock, processors, and seed and deducting the stocks in all positions as of January $1,1978$.
}

Table 2. Production, Farm Use, and Sales of Sorghum by State for the 1977 Crop

\begin{tabular}{|c|c|c|c|}
\hline State & Production & $\begin{array}{l}\text { Used on } \\
\text { farms } \\
\text { where } \\
\text { produced }\end{array}$ & Sales \\
\hline & \multicolumn{3}{|c|}{ thousands of bushels } \\
\hline $\begin{array}{l}\text { Alabama .......... } \\
\text { Arizona .......... } \\
\text { Arkansas ........ } \\
\text { California ........ }\end{array}$ & $\begin{array}{r}729 \\
7,200 \\
13,104 \\
9,636\end{array}$ & $\begin{array}{r}576 \\
720 \\
2,228 \\
964\end{array}$ & $\begin{array}{r}153 \\
6,480 \\
10,876 \\
8,672\end{array}$ \\
\hline $\begin{array}{l}\text { Colorado ......... } \\
\text { Georgia ......... } \\
\text { Illinois ........... } \\
\text { Indiana .......... }\end{array}$ & $\begin{array}{r}8,153 \\
672 \\
4,096 \\
1,170\end{array}$ & $\begin{array}{r}2,201 \\
511 \\
2,212 \\
550\end{array}$ & $\begin{array}{r}5,952 \\
161 \\
1.884 \\
620\end{array}$ \\
\hline $\begin{array}{l}\text { lowa.............. } \\
\text { Kansas .......... } \\
\text { Kentucky ....... } \\
\text { Louisiana . . . . . }\end{array}$ & $\begin{array}{r}2,368 \\
243,000 \\
1,824 \\
660\end{array}$ & $\begin{array}{r}1,279 \\
89,910 \\
1,058 \\
264\end{array}$ & $\begin{array}{r}1,089 \\
153,090 \\
766 \\
396\end{array}$ \\
\hline $\begin{array}{l}\text { Mississippi ........ } \\
\text { Missouri .......... } \\
\text { Nebraska ......... } \\
\text { New Mexico ...... }\end{array}$ & $\begin{array}{r}768 \\
67,890 \\
146,970 \\
11,760\end{array}$ & $\begin{array}{r}276 \\
31,908 \\
36,742 \\
2,117\end{array}$ & $\begin{array}{r}492 \\
35,982 \\
110,228 \\
9,643\end{array}$ \\
\hline $\begin{array}{l}\text { North Carolina ..... } \\
\text { Oklahoma ........ } \\
\text { South Carolina ..... } \\
\text { South Dakota ..... }\end{array}$ & $\begin{array}{r}2,664 \\
21,470 \\
192 \\
16,807\end{array}$ & $\begin{array}{r}1,385 \\
8,588 \\
154 \\
7,899\end{array}$ & $\begin{array}{r}1,279 \\
12,882 \\
38 \\
8,908\end{array}$ \\
\hline $\begin{array}{l}\text { Tennessee ........ } \\
\text { Texas ............ } \\
\text { Virginia ........... }\end{array}$ & $\begin{array}{r}1,020 \\
230,400 \\
430 \\
\end{array}$ & $\begin{array}{r}816 \\
57,600 \\
387 \\
\end{array}$ & $\begin{array}{r}204 \\
172,800 \\
43 \\
\end{array}$ \\
\hline U.S. Total ........... & 792,983 & 250,345 & 542,638 \\
\hline
\end{tabular}

Source: Field Crops: Production, Disposition, Value, 1977-1978, Economics and Statistics Service, U.S. Department of Agriculture, CrPr 1 (79) (April 11, 1979), p. 6.

available for shipment from each state. Exact correspondence between the supply and reported shipments was not expected since the data on sorghum consumption by livestock and processors were based on estimates. Any major discrepancies, however, were investigated to verify that they did not indicate significant errors in the survey data.

A second check on total volume was made by comparing total receipts at each port with official data on inspections for export as published by the Market News Service of the U.S. Department of Agriculture (Table 4). Because there were few opportunities for either set of data to miss significant volumes, these numbers compared very closely. Discrepancies between receipts and exports at some of the port areas were explained by shipments to domestic destinations from export elevators, shipments to processing plants located in the port area, and changes in inventory.

Supplemental information about grain shipments on inland waterways was provided by the U.S. Army Corps 


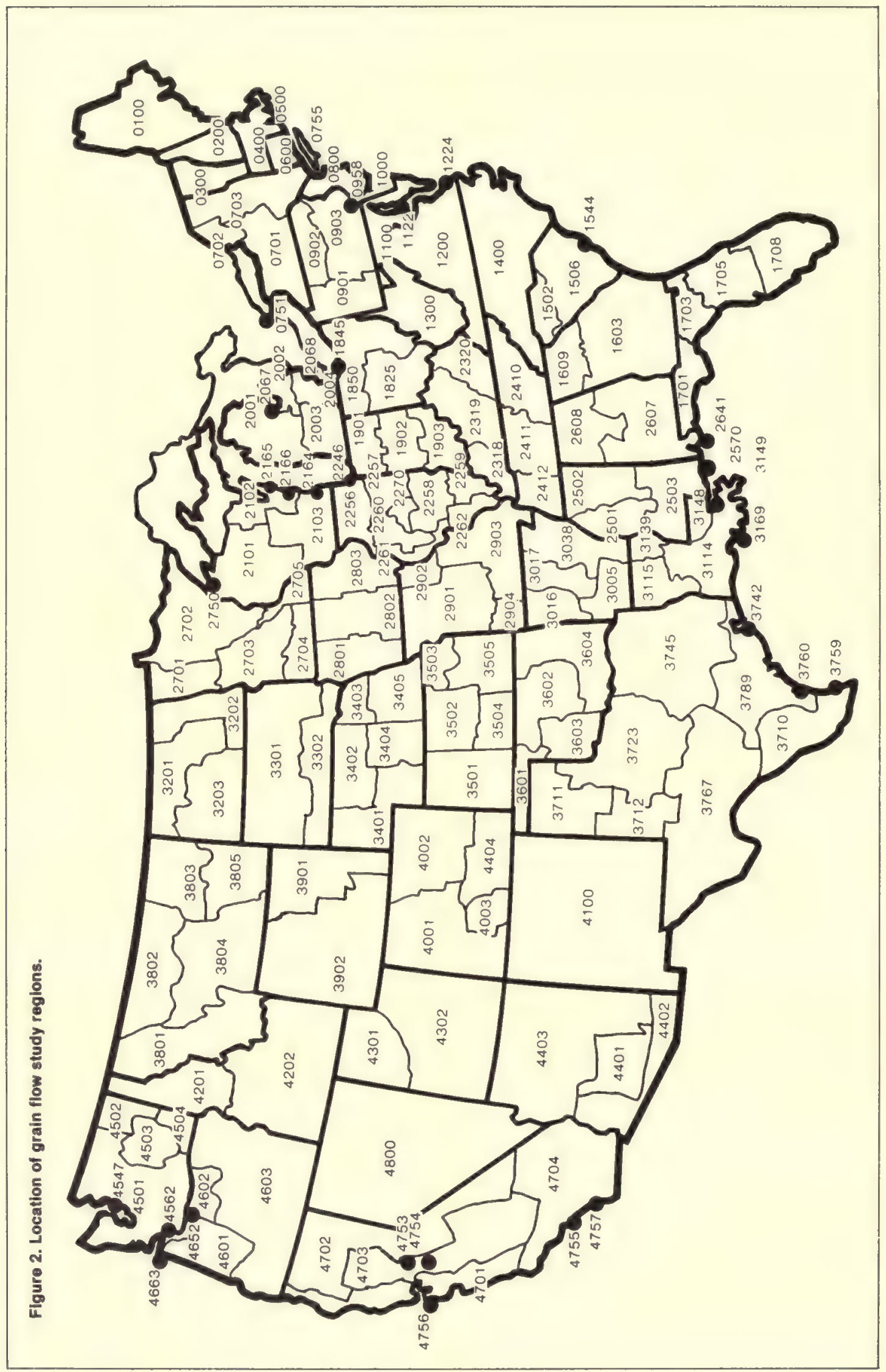


Table 3. Export Regions, Port Areas, and the Ports Included in Each Area

\begin{tabular}{|c|c|c|c|}
\hline \multicolumn{2}{|c|}{ Export region and port area ${ }^{a}$} & \multicolumn{2}{|c|}{ Ports included in the general area } \\
\hline $\begin{array}{c}\text { Area } \\
\text { number }\end{array}$ & Export area & $\begin{array}{c}\text { Port } \\
\text { number }\end{array}$ & Port city \\
\hline \multicolumn{4}{|c|}{ Great Lakes Region } \\
\hline 7101 & Duluth-Superior & 2750 & $\begin{array}{l}\text { Duluth, MN } \\
\text { Superior, WI }\end{array}$ \\
\hline \multirow[t]{4}{*}{7102} & Chicago & 2164 & Milwaukee, WI \\
\hline & & 2165 & Manitowoc, WI \\
\hline & & 2166 & Racine, WI \\
\hline & & 2246 & Chicago, IL \\
\hline \multirow[t]{4}{*}{7103} & Toledo & 1845 & Toledo, $\mathrm{OH}$ \\
\hline & & & Huron, $\mathrm{OH}$ \\
\hline & & & Erie, PA \\
\hline & & 0751 & Buffalo, NY \\
\hline \multirow[t]{4}{*}{7104} & Saginaw & 2067 & Carrollton, MI \\
\hline & & & Saginaw, MI \\
\hline & & & Zilwaukee, MI \\
\hline & & 2068 & Detroit, MI \\
\hline \multicolumn{4}{|c|}{ Atlantic Region } \\
\hline \multirow[t]{3}{*}{7201} & North Atlantic & 0101 & Portland, ME \\
\hline & & 0755 & Albany, NY \\
\hline & & 0958 & Philadelphia, PA \\
\hline \multirow[t]{3}{*}{7202} & South Atlantic & 1122 & Baltimore, MD \\
\hline & & 1224 & Norfolk, VA \\
\hline & & 1544 & North Charleston, SC \\
\hline \multicolumn{4}{|c|}{ Gulf Region } \\
\hline \multirow[t]{2}{*}{7301} & East Gulf & 2570 & Pascagoula, MS \\
\hline & & 2641 & Mobile, AL \\
\hline \multirow[t]{2}{*}{7302} & Louisiana Gulf & 3149 & Mississippi River \\
\hline & & 3169 & Lake Charles, LA \\
\hline \multirow[t]{4}{*}{7303} & North Texas Gulf & 3742 & Beaumont, TX \\
\hline & & & Port Arthur, TX \\
\hline & & & Houston, TX \\
\hline & & & Galveston, TX \\
\hline \multirow[t]{2}{*}{7304} & South Texas Gulf & 3759 & Brownsville, TX \\
\hline & & 3760 & Corpus Christi, TX \\
\hline \multicolumn{4}{|c|}{ Pacific Region } \\
\hline \multirow[t]{5}{*}{7401} & Columbia River & 4562 & Kalama, WA \\
\hline & & & Longview, WA \\
\hline & & & Vancouver, WA \\
\hline & & 4652 & Portland, OR \\
\hline & & 4663 & Astoria, OR \\
\hline \multirow[t]{2}{*}{7402} & Puget Sound & 4547 & Seattle, WA \\
\hline & & & Tacoma, WA \\
\hline \multirow[t]{5}{*}{7403} & California Ports & 4753 & Sacramento, CA \\
\hline & & 4754 & Stockton, CA \\
\hline & & 4755 & Long Beach, CA \\
\hline & & 4756 & San Francisco, CA \\
\hline & & 4757 & San Diego, CA \\
\hline
\end{tabular}

- These port areas will be used in this report to avoid disclosure of data from individual firms. 
of Engineers. Since these data were based on the actual bill of lading for each shipment they were, in principle, a complete census of all barge shipments. As Table 5 shows, the survey data and the Corps data on state-tostate shipments on inland waterways correspond closely. Differences between the two sets of data can be explained by (1) a significant number of shipments for which the origins and destinations are noted as "unknown" in the Corps data, (2) changes in the destination of a barge after it left the loading dock, (3) incomplete reporting of loadings to the Corps of Engineers, and (4) reporting errors by survey respondents. The sizeable shipments from Minnesota in the Corps data sug gest that errors may be present in recording the type of grain being shipped since sorghum is not produced in that state.

The last method of validation provides important insight into data available from the U.S. Department of Transportation that are based on a 1 percent sample of all rail bills of lading. These data were expanded to develop estimates of annual shipments and receipts in each state and then compared with the rail shipments reported by survey respondents (Table 6). There are many similarities, but there are also a few major differences. In Nebraska, for example, intrastate shipments were seriously understated in the 1 percent waybill sample.

Table 4. Comparison of 1977 Sorghum Receipts, Shipments, and Inspections for Export at Various Port Areas

\begin{tabular}{|c|c|c|c|}
\hline \multirow{2}{*}{$\begin{array}{l}\text { Port } \\
\text { area }^{a}\end{array}$} & \multicolumn{2}{|c|}{$\begin{array}{c}\text { Quantities determined } \\
\text { by survey }\end{array}$} & \multirow{2}{*}{$\begin{array}{l}\text { Inspections } \\
\text { - for export }\end{array}$} \\
\hline & Receipts & Exports & \\
\hline
\end{tabular}

\section{Great Lakes Region}

thousands of bushels

\begin{tabular}{|c|c|c|c|}
\hline Atlantic Region ..... & 0 & 0 & 0 \\
\hline \multicolumn{4}{|l|}{ Gulf Region } \\
\hline East Gulf ......... & 0 & 0 & 0 \\
\hline Louisiana Gulf .... & 11,126 & 7,854 & 5,526 \\
\hline North Texas Gulf & 135,425 & 132,010 & 127,062 \\
\hline South Texas Gulf & 93,300 & 91,100 & 91,173 \\
\hline Subtotal......... & 239,851 & 230,964 & 223,761 \\
\hline
\end{tabular}

\section{Pacific Region}

\begin{tabular}{|c|c|c|c|}
\hline Columbia River ... & 15 & 15 & \\
\hline Puget Sound ..... & 2,196 & 1,641 & 1,378 \\
\hline California .......... & 2,093 & 1,919 & 1,869 \\
\hline Subtotal & 4,304 & 3,575 & 3,247 \\
\hline & 244,155 & 234,539 & 227,008 \\
\hline
\end{tabular}

See Table 3 for a list of ports.

b Inspections for export under the U.S. Grain Standards Act and reported in Grain Market News, Agricultural Marketing Service, U.S. Department of Agriculture, Vol. 26, No. 2 (January 13, 1978), p. 18.
The comparisons between various data sources increase the confidence in the accuracy of estimates derived from sampling a less than perfectly identified population. The logic of each flow reported in these tables has been checked by the university person that organized the survey in each state. Where internal inconsistencies were found, the data and the sampling rates were adjusted with assistance from grain specialists and industry personnel in the state. The flow esti-

Table 5. Comparison of 1977 Waterway Movements of Sorghum In the U.S. as Reported by Survey Respondents and the U.S. Army Corps of Engineers

\begin{tabular}{|c|c|c|c|}
\hline $\begin{array}{l}\text { Originating } \\
\text { state }\end{array}$ & $\begin{array}{c}\text { Destination } \\
\text { state }\end{array}$ & $\begin{array}{l}\text { Survey } \\
\text { results }\end{array}$ & $\begin{array}{c}\text { Corps of } \\
\text { Engineers } \\
\text { data }\end{array}$ \\
\hline & & \multicolumn{2}{|c|}{ thousands of bushels } \\
\hline \multirow[t]{3}{*}{ Arkansas } & Louisiana & 2,010 & 723 \\
\hline & Texas & 0 & 200 \\
\hline & Subtotal & 2,010 & 923 \\
\hline \multirow[t]{3}{*}{ Florida } & Louisiana & 246 & 66 \\
\hline & Texas & 0 & 224 \\
\hline & Subtotal & 246 & 290 \\
\hline \multirow[t]{4}{*}{ Illinois } & Louisiana & 100 & 616 \\
\hline & Texas & 989 & 153 \\
\hline & Other & O & 88 \\
\hline & Subtotal & 1,089 & 857 \\
\hline lowa & Texas & 0 & 38 \\
\hline Kansas & Louisiana & 552 & 214 \\
\hline \multirow[t]{3}{*}{ Kentucky } & Louisiana & 0 & 46 \\
\hline & Texas & $\underline{0}$ & 98 \\
\hline & Subtotal & 0 & 144 \\
\hline \multirow[t]{3}{*}{ Louisiana } & Louisiana & 160 & 174 \\
\hline & Texas & 0 & 196 \\
\hline & Subtotal & 160 & 370 \\
\hline \multirow[t]{3}{*}{ Minnesota } & Louisiana & 0 & 1,381 \\
\hline & Missouri & 0 & 351 \\
\hline & Subtotal & 0 & 2,732 \\
\hline Mississippi & Louisiana & 0 & 48 \\
\hline \multirow[t]{3}{*}{ Missouri } & Louisiana & 2,966 & 2,566 \\
\hline & Texas & 1,024 & 1,510 \\
\hline & Subtotal & 3,990 & 4,076 \\
\hline \multirow[t]{3}{*}{ Oklahoma } & Louisiana & 0 & 71 \\
\hline & Texas & $\underline{0}$ & 54 \\
\hline & Subtotal & 0 & 125 \\
\hline \multirow[t]{3}{*}{ Tennessee } & Louisiana & 815 & 816 \\
\hline & Texas & 0 & 210 \\
\hline & Subtotal & 815 & 1,026 \\
\hline Texas & Texas & 0 & 1,266 \\
\hline U.S. Total & & 8,862 & 12,061 \\
\hline
\end{tabular}


mates presented in the following sections represent the best information available on the actual volume of sorghum transported between the regions of the United States.

Table 6. Comparison of 1977 Rall Movements of Sorghum as Reported by Survey Respondents and as Estimated from the 1 Percent Waybill Sample in Selected States

Originating Destination Survey Waybill
state state results data

\begin{tabular}{|c|c|c|c|}
\hline \multirow{5}{*}{ Colorado } & \multirow{4}{*}{$\begin{array}{l}\text { California } \\
\text { Texas } \\
\text { Other }\end{array}$} & \multicolumn{2}{|c|}{ thousands of bushels } \\
\hline & & 3,979 & 4,120 \\
\hline & & 1,604 & 1,078 \\
\hline & & 178 & 692 \\
\hline & Subtotal & 5,761 & 5,890 \\
\hline \multirow[t]{11}{*}{ Kansas } & Arkansas & 5,007 & 1,349 \\
\hline & Arizona & 4,955 & 2,442 \\
\hline & California & 8,420 & 8,968 \\
\hline & Colorado & 768 & 2,856 \\
\hline & Kansas & 31,316 & 30,424 \\
\hline & Louisiana & 802 & 0 \\
\hline & Missouri & 7,229 & 3,952 \\
\hline & Oklahoma & 2,785 & 2,967 \\
\hline & Texas & 49,622 & 51,772 \\
\hline & Other & 324 & $\begin{array}{r}468 \\
-\end{array}$ \\
\hline & Subtotal & 111,228 & 105,197 \\
\hline \multirow[t]{9}{*}{ Missouri } & Arkansas & 1,635 & 1,164 \\
\hline & California & 2,075 & 0 \\
\hline & Kansas & 1,966 & 1,496 \\
\hline & Louisiana & 17 & 668 \\
\hline & Missouri & 8,313 & 3,184 \\
\hline & Texas & 14,607 & 14,430 \\
\hline & Washington & 172 & 428 \\
\hline & Other & 99 & 0 \\
\hline & Subtotal & 28,893 & 21,370 \\
\hline \multirow[t]{9}{*}{ Nebraska } & Arizona & 1,295 & 1,699 \\
\hline & California & 4,373 & 4,455 \\
\hline & Colorado & 1,890 & 1,710 \\
\hline & Kansas & 11,147 & 12,374 \\
\hline & Missouri & 574 & 4,109 \\
\hline & Nebraska & 52,194 & 6,087 \\
\hline & Texas & 58,374 & 60,412 \\
\hline & Other & 1,341 & 7,511 \\
\hline & Subtotal & 131,287 & 98,357 \\
\hline \multirow[t]{4}{*}{ Oklahoma } & Oklahoma & 215 & 1,653 \\
\hline & Texas & 3,538 & 2,463 \\
\hline & Other & 725 & 361 \\
\hline & Subtotal & 4,478 & 4,477 \\
\hline \multirow[t]{5}{*}{ Texas } & Arizona & 2,850 & 4,152 \\
\hline & California & 11,082 & 9,639 \\
\hline & Texas & 61,706 & 50,737 \\
\hline & Other & 3,358 & 0 \\
\hline & Subtotal & 78,996 & 64,528 \\
\hline
\end{tabular}

\section{OVERVIEW OF MOVEMENTS}

This section summarizes selected data and presents a general overview of sorghum movement patterns. Detailed data on receipts and shipments for each region are presented in the last section of this bulletin.

\section{Shipments and Receipts by State}

In 1977, grain marketing firms in the United States reported shipping about 671 million bushels of sorghum. About 60 percent of the amount shipped moved to destinations within the state in which it originated. Much of the total amount, of course, is accounted for by the same grain being shipped in sequence by several firms. Intrastate shipments for each state and mode of transportation are summarized in Table 7. Trucks were the predominant mode of transportation, accounting for about 58 percent of the total intrastate shipments. Rail shipments accounted for 38 percent of the total amount shipped, and 4 percent moved to local farmers. A sizeable portion of the intrastate movements consisted of shipments from country elevators to terminal elevators for storage and reshipment. Movements within the state of Texas accounted for more than one-half of the total volume of intrastate movements in the United States. Sizeable movements also occurred within the states of Kansas and Nebraska.

In contrast to intrastate movements, the predominant mode of transportation used for interstate shipments was the railroad, which carried 217 million bushels or 83 percent of the total volume (Table 8). Almost threefourths of the volume moving by railroads originated in Kansas and Nebraska. Kansas, Texas, and California were the principal destinations for shipments originating in Nebraska. Texas and California were the principal destinations for Kansas's rail shipments, and Arkansas, Missouri, and Arizona were also important destinations. Over 5 million bushels moved by rail from Kansas to each of these states.

Interstate truck movements originating in Kansas accounted for almost one-half of the volume shipped across state lines by truck. Most of these shipments moved short distances to the neighboring states of Missouri, Oklahoma, and Texas, where some of the grain was used by feed processors and the balance was stored and later reshipped to port areas.

Barges carried only 3.3 percent of the sorghum shipped across state lines, and Arkansas, Illinois, and Missouri originated 81.5 percent of the total volume shipped in the U.S. by barge. All sorghum shipped by barge, regardless of the state in which it originated, was destined for Gulf Ports.

The volume of sorghum received in each state from other states is shown in Table 9. Texas port areas were the predominant destinations. Arizona and California were the most important domestic markets in the West while Arkansas and Louisiana were important domestic markets in the South. The domestic flow pattern for sorghum is illustrated in Figure 3. 
Table 7. 1977 Intrastate Shipments of Sorghum for Each State and Mode of Transportation

\begin{tabular}{|c|c|c|c|c|c|}
\hline \multirow{2}{*}{$\begin{array}{l}\text { Originating } \\
\text { state }\end{array}$} & \multicolumn{4}{|c|}{ Mode of transportation } & \multirow{2}{*}{ Total } \\
\hline & Rail & Truck & Barge & Farm truck & \\
\hline & \multicolumn{5}{|c|}{ thousands of bushels } \\
\hline 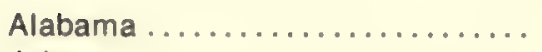 & 10 & 47 & 0 & 0 & 57 \\
\hline 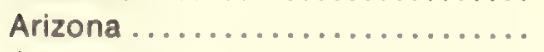 & 583 & 8,065 & 0 & 4,109 & 12,757 \\
\hline 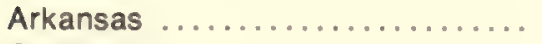 & 0 & 10,521 & 0 & 78 & 10,599 \\
\hline 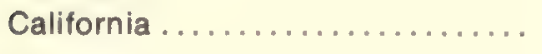 & 1,543 & 2,316 & 0 & 0 & 3,859 \\
\hline 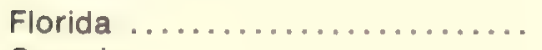 & 0 & 76 & 0 & 0 & 76 \\
\hline Georgia ..................... & 0 & 52 & 0 & 2 & 54 \\
\hline 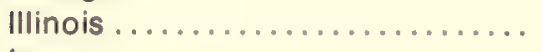 & 0 & 226 & 0 & 150 & 376 \\
\hline 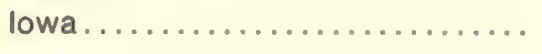 & 0 & 183 & 0 & 0 & 183 \\
\hline 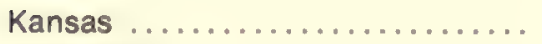 & 31,316 & 17,097 & 0 & 0 & 48,413 \\
\hline Louisiana .................... & 0 & 623 & 160 & 0 & 783 \\
\hline Mississippi ..................... & 0 & 82 & 0 & 0 & 82 \\
\hline 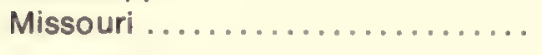 & 8,313 & 5,943 & 0 & 0 & 14,256 \\
\hline 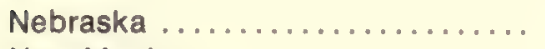 & 52,194 & 31,269 & 0 & 7,553 & 91,016 \\
\hline New Mexico ................... & 0 & 0 & 0 & 5,447 & 5,447 \\
\hline North Carolina ............... & 32 & 32 & 0 & 0 & 64 \\
\hline 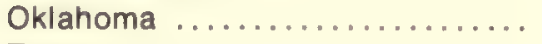 & 215 & 215 & 0 & 0 & 430 \\
\hline 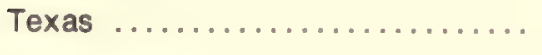 & 61,706 & $\underline{158,400}$ & 0 & 0 & $\underline{220,106}$ \\
\hline Total volume .................. & 155,912 & 235,147 & 160 & 17,339 & 408,558 \\
\hline
\end{tabular}

Percentage of

total volume ....................

38.2

57.6

0

4.2

100.0

a This column reports sales by elevators to farmers within the state. Not all states included farm sales in their survey responses, so these data are incomplete and underestimate total shipments to farmers.

Figure 3. Patterns of sorghum flow to domestic destinations, 1977.

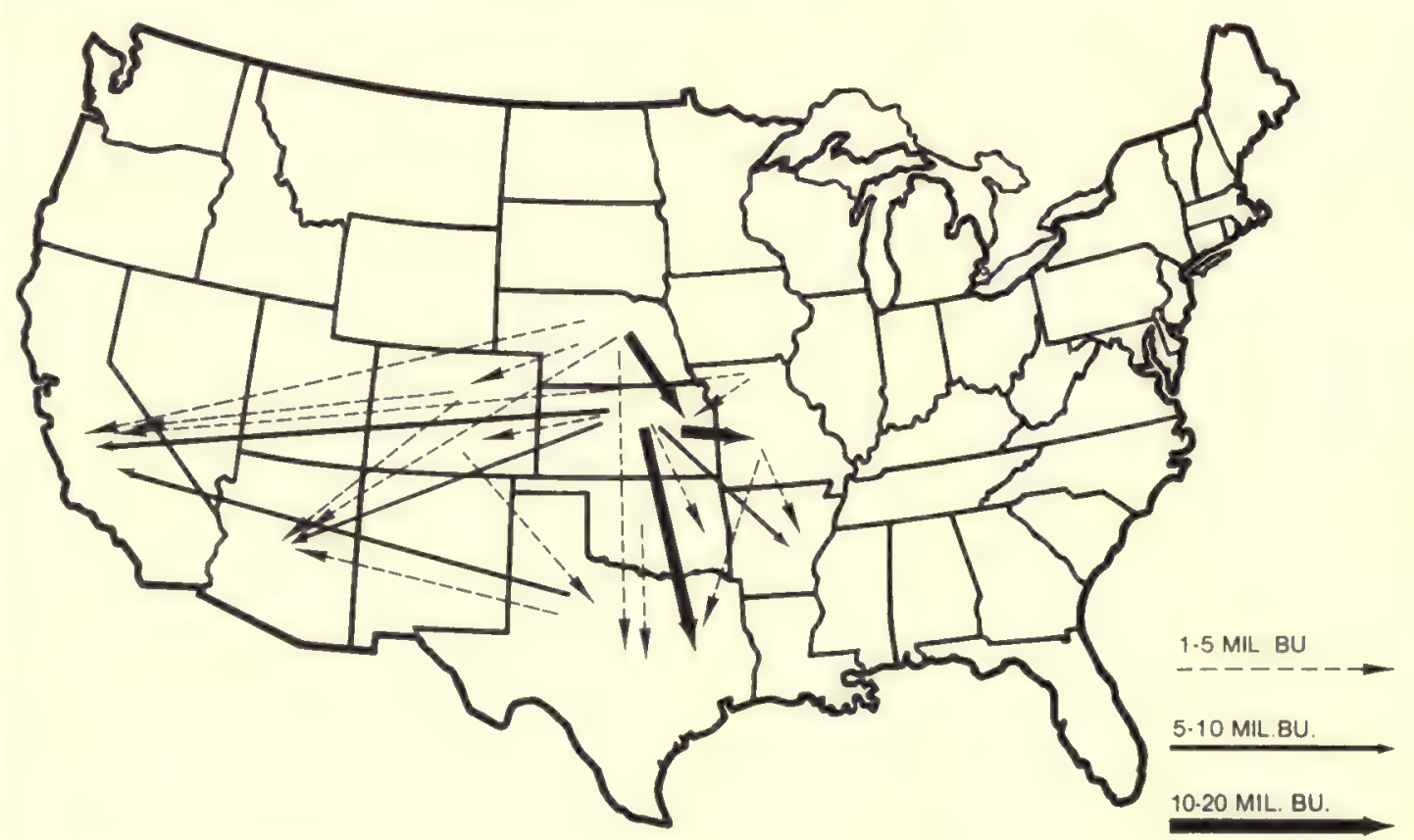


Table 8. 1977 Interstate Shipments of Sorghum for Each State and Mode of Transportation

\begin{tabular}{|c|c|c|c|c|c|}
\hline \multirow{2}{*}{$\begin{array}{l}\text { Originating } \\
\text { state }\end{array}$} & \multicolumn{4}{|c|}{ Mode of transportation } & \multirow{2}{*}{ Total } \\
\hline & Rail & Truck & Barge & Farm truck & \\
\hline & \multicolumn{5}{|c|}{ thousands of bushels } \\
\hline 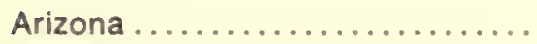 & 94 & 71 & 0 & 0 & 165 \\
\hline 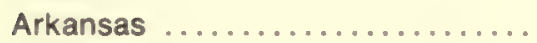 & 5,838 & 2,429 & 2,010 & 0 & 10,277 \\
\hline 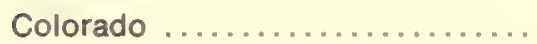 & 5,761 & 927 & 0 & 0 & 6,688 \\
\hline Florida...$\ldots \ldots \ldots \ldots \ldots$ & 0 & 0 & 246 & 0 & 246 \\
\hline 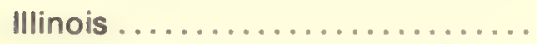 & 1,938 & 284 & 1,089 & 0 & 3,311 \\
\hline 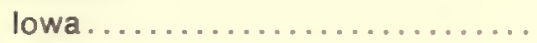 & 2,054 & 258 & 0 & 0 & 2,312 \\
\hline 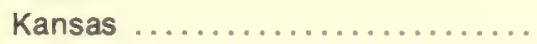 & 79,912 & 16,448 & 552 & 171 & 97,083 \\
\hline 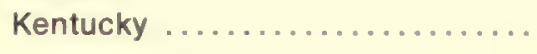 & 0 & 32 & 0 & 0 & 32 \\
\hline Louisiana .................... & 12 & 51 & 0 & 0 & 63 \\
\hline Missouri ....................... & 20,580 & 3,080 & 3,990 & 0 & 27,650 \\
\hline 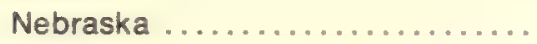 & 78,994 & 3,974 & 0 & 1,796 & 84,764 \\
\hline 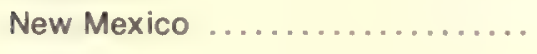 & 484 & 3,724 & 0 & 0 & 4,208 \\
\hline 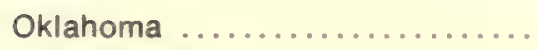 & 4,263 & 1,535 & 0 & 0 & 5,798 \\
\hline South Dakota ................... & 98 & 28 & 0 & 0 & 126 \\
\hline Tennessee ..................... & 0 & 32 & 815 & 0 & 847 \\
\hline 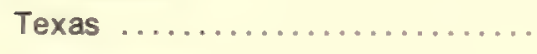 & $17,290^{b}$ & 1,700 & 0 & 0 & 18,990 \\
\hline Total volume ................... & 217,318 & 34,573 & 8,702 & 1,967 & 262,560 \\
\hline $\begin{array}{l}\text { Percentage of } \\
\text { total volume } \ldots . . . \ldots \ldots \ldots . . . . .\end{array}$ & 82.8 & 13.2 & 3.3 & 0.7 & 100.0 \\
\hline
\end{tabular}

a This column reports sales by elevators to farmers in other states. Not all states included farm sales in their survey responses, so these data are incomplete and underestimate total shipments to farmers.

'Includes 2,780,000 bushels shipped by rail to Mexico.

\section{Movements to Ports}

Table 10 shows the amount of sorghum that moved to port locations from each of the originating states by the various modes of transportation. Almost one-half of the volume of sorghum that moved to ports originated in Texas, and the Gulf region accounted for 98.5 percent of the total amount received by all ports. Over 64 percent of the sorghum shipped to ports went by rail. Nebraska, Kansas, and Texas were the states that shipped the largest volume of sorghum by rail for export, accounting for over 85 percent of the total amount of sorghum shipped to the port regions. Missouri shipped a significant amount by rail and ranked fourth among all states that originated sorghum rail shipments to port regions. Thirty-two percent of the sorghum shipped to port regions went by truck. Texas was the state that shipped the largest amount by truck, accounting for almost 94 percent of the 79 million bushels that moved by truck to ports. Less than 9 million bushels were shipped by barge to port regions, and over one-half of this volume originated in Missouri. These movements are illustrated in Figure 4.

Each state's share of the total volume of sorghum shipped to port regions is shown in Figure 5. Texas was the state that shipped the greatest amount of sorghum for export, accounting for 48.6 percent of the total amount shipped. Nebraska and Kansas shipped significant volumes, ranking second and third, respectively, among all states that originated sorghum shipments to port locations. Combined, these two states accounted for almost two-fifths of the total volume moving to port locations.

The estimated amount of sorghum received at all port areas in 1977 totaled 243 million bushels, of which 227 million bushels were inspected for export (Table 11). The remainder was either processed or represented increases in sorghum stocks at port elevators during 1977. Over 98 percent of sorghum exports were handled by Gulf port elevators, and the North Texas Gulf was the predominant port area, accounting for 56 percent of the total volume exported. The South Texas Gulf area ranked second on the basis of volume, and over 91 million bushels were handled through those facilities in 1977.

\section{Foreign Destinations for U.S. Exports}

Sorghum shipped from the various origins to a specific port area is blended and stored on a commingled basis. Thus it is not possible to trace the movement of 
sorghum from a particular state through the port system to its final destination, and therefore no attempt was made to determine whether a particular ocean vessel was loaded with, for example, Kansas sorghum or Texas sorghum. It is nonetheless of interest to examine one more link in the market chain that connects U.S. farmers with foreign feeders and processors.

The destination countries for sorghum exported from the major port regions of the United States are shown in Table 12. In 1977 Japan was the leading buyer of U.S. sorghum, accounting for 89 million bushels or 39 percent of the total volume exported. Israel, Mexico, Portugal, and Spain were the next most important destinations and in combination purchased about the same quantity as Japan. Venezuela and Columbia were major destinations in South America, and sizeable quantities were shipped to European countries.

Data on receipts and shipments for individual state and substate areas delineated in the survey are presented in the following section.

Table 9. 1977 Interstate Receipts of Sorghum for Each State and Mode of Transportation

\begin{tabular}{|c|c|c|c|c|c|}
\hline \multirow{2}{*}{$\begin{array}{l}\text { Destination } \\
\text { state }\end{array}$} & \multicolumn{4}{|c|}{ Mode of transportation } & \multirow{2}{*}{ Total } \\
\hline & Rail & Truck & Barge & Farm truck ${ }^{\mathrm{a}}$ & \\
\hline & \multicolumn{5}{|c|}{ thousands of bushels } \\
\hline 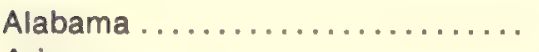 & 233 & 80 & 0 & 0 & 313 \\
\hline 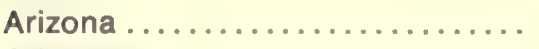 & 9,624 & 2,934 & 0 & 0 & 12,558 \\
\hline 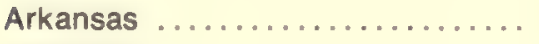 & 6,894 & 1,551 & 0 & 0 & 8,445 \\
\hline California .................... & 30,431 & 243 & 0 & 0 & 30,674 \\
\hline Colorado .................... & 2,658 & 876 & 0 & 0 & 3,534 \\
\hline Connecticut ................ & 167 & 0 & 0 & 0 & 167 \\
\hline Illinois . ...................... & 83 & 214 & 0 & 0 & 297 \\
\hline 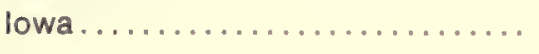 & 133 & 96 & 0 & 0 & 229 \\
\hline 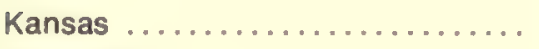 & 13,362 & 4,002 & 0 & 0 & 17,364 \\
\hline Kentucky .................... & 86 & 0 & 0 & 0 & 86 \\
\hline Louisiana .................... & 6,036 & 52 & 6,689 & 0 & 12,777 \\
\hline 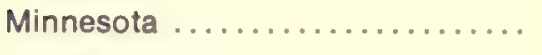 & 203 & 28 & 0 & 0 & 231 \\
\hline Mississippi ..................... & 303 & 368 & 0 & 0 & 671 \\
\hline 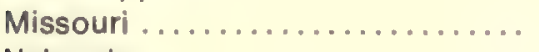 & 7,929 & 4,595 & 0 & 946 & 13,470 \\
\hline Nebraska .................... & 14 & 23 & 0 & 288 & 325 \\
\hline 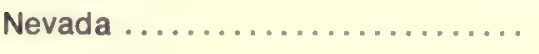 & 3 & 0 & 0 & 0 & 3 \\
\hline New Mexico ................... . & 0 & 12 & 0 & 0 & 12 \\
\hline Ohio ..................... & 125 & 0 & 0 & 0 & 125 \\
\hline Okiahoma ................... & 2,922 & 1,898 & 0 & 0 & 4,820 \\
\hline 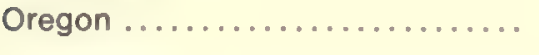 & 15 & 0 & 0 & 0 & 15 \\
\hline Tennessee .................... & 675 & 160 & 0 & 48 & 883 \\
\hline 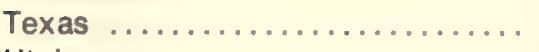 & 132,022 & 15,576 & 2,013 & 0 & 149,611 \\
\hline 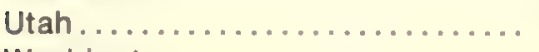 & 289 & 0 & 0 & 0 & 289 \\
\hline 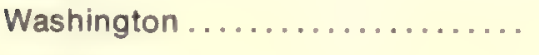 & 331 & 1,865 & 0 & $\underline{0}$ & 2,196 \\
\hline Total volume .................. & 214,538 & 34,573 & 8,702 & 1,282 & 259,095 \\
\hline $\begin{array}{l}\text { Percentage of } \\
\text { total volume } \ldots \ldots \ldots \ldots \ldots \ldots . . . . . .\end{array}$ & 82.8 & 13.3 & 3.4 & 0.5 & 100.0 \\
\hline
\end{tabular}

a This column shows elevator receipts in each state from farmers located in all other states as reported by elevators in the receiving states. 
Figure 4. Patterns of sorghum flow to port areas, 1977.

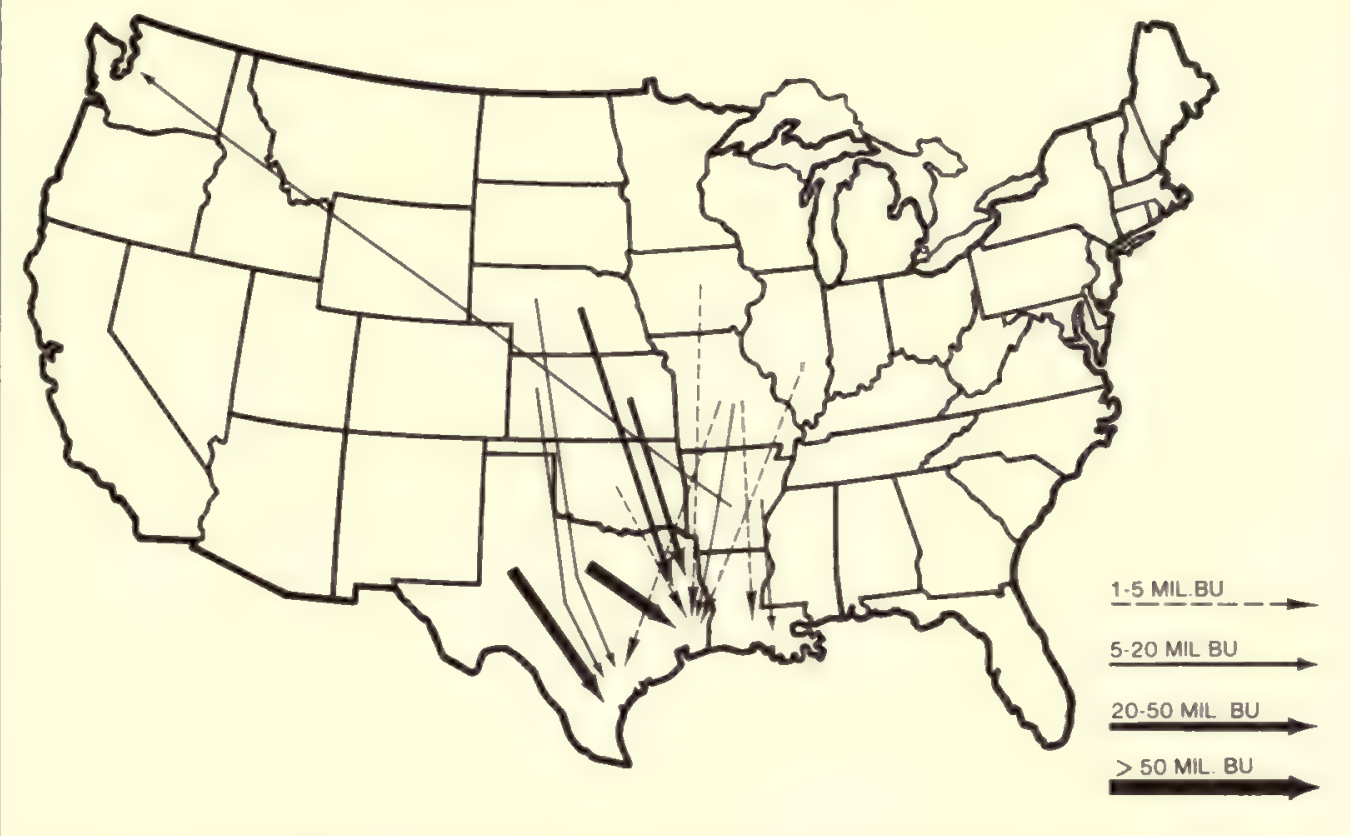

Table 10. 1977 Movements of Sorghum to Points of Export for Each Originating State by Three Modes of Transportation

\begin{tabular}{|c|c|c|c|c|c|}
\hline \multirow{2}{*}{$\begin{array}{l}\text { Originating } \\
\text { state }\end{array}$} & \multirow{2}{*}{$\begin{array}{l}\text { Export } \\
\text { region }\end{array}$} & \multicolumn{3}{|c|}{ Mode of transportation } & \multirow{2}{*}{ Total } \\
\hline & & Rail & Truck & Barge & \\
\hline & & \multicolumn{4}{|c|}{ thousands of bushels } \\
\hline Arizona............. & Gulf ............... & 94 & 0 & 0 & 94 \\
\hline \multirow{2}{*}{ Arkansas ............... } & Gulf ................. & 4,865 & 0 & 2,010 & 6,875 \\
\hline & Pacific $\ldots . . . . . . .$. & 0 & 1,865 & 0 & 1,865 \\
\hline Florida & 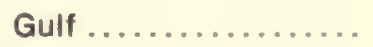 & 0 & 0 & 246 & 246 \\
\hline Illinois . . & Gulf ................. & 1,128 & 0 & 1,089 & 2,217 \\
\hline 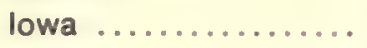 & Gulf ................ & 1,941 & 0 & 0 & 1,941 \\
\hline \multirow[t]{2}{*}{ 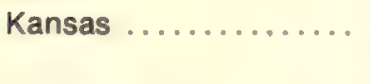 } & Gulf ................ & 38,949 & 3,114 & 552 & 42,615 \\
\hline & Pacific ............. & 241 & 0 & 0 & 241 \\
\hline Louisiana............ & Gulf ................ & 12 & 22 & 160 & 194 \\
\hline \multirow{2}{*}{ Missouri .............. } & Gulf ................. & 10,514 & 13 & 3,990 & 14,517 \\
\hline & Pacific .............. & 172 & 0 & 0 & 172 \\
\hline \multirow[t]{2}{*}{ Nebraska. } & Gulf ................ & 53,779 & 45 & 0 & 53,824 \\
\hline & Pacific .............. & 1,285 & 0 & 0 & 1,285 \\
\hline New Mexico . & 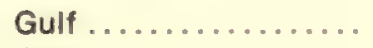 & 122 & 0 & 0 & 122 \\
\hline Oklahoma ....... & Gulf $\ldots \ldots \ldots \ldots$ & 2,186 & 0 & 0 & 2,186 \\
\hline Tennessee........... & Gulf ................ & 0 & 0 & 815 & 815 \\
\hline \multirow[t]{3}{*}{ Texas .................... } & Gulf ................. & 39,045 & 74,160 & 0 & 113,205 \\
\hline & Pacific ............. & 187 & 0 & 0 & 187 \\
\hline & Mexico .............. & 2,780 & 0 & 0 & 2,780 \\
\hline \multirow[t]{3}{*}{ All states. } & Gulf ................ & 152,635 & 77,354 & 8,862 & 238,851 \\
\hline & Pacific ............. & 1,885 & 1,865 & 0 & 3,750 \\
\hline & Mexico ............... & 2,780 & 0 & 0 & 2,780 \\
\hline \multicolumn{2}{|l|}{ Total volume..... } & 157,300 & 79,219 & 8,862 & 245,381 \\
\hline \multicolumn{2}{|l|}{$\begin{array}{l}\text { Percentage of } \\
\text { total volume.. }\end{array}$} & 64.1 & 32.3 & 3.6 & 100.0 \\
\hline
\end{tabular}


Table 11. 1977 Receipts of Sorghum at Port Areas by Each Mode of Transportation

\begin{tabular}{|c|c|c|c|c|c|c|}
\hline \multirow{2}{*}{$\begin{array}{c}\text { Export region } \\
\text { and } \\
\text { port area }\end{array}$} & \multicolumn{4}{|c|}{ Mode of transportation } & \multirow{2}{*}{$\begin{array}{l}\text { Total } \\
\text { receipts }\end{array}$} & \multirow{2}{*}{$\begin{array}{c}\text { Inspections } \\
\text { for } \\
\text { export }\end{array}$} \\
\hline & Rail & Truck & Barge & Farm truck & & \\
\hline & \multicolumn{6}{|c|}{ thousands of bushels } \\
\hline Great Lakes Region & 0 & 0 & 0 & 0 & 0 & 0 \\
\hline Atlantic Region ............ & 0 & 0 & 0 & 0 & 0 & 0 \\
\hline \multicolumn{7}{|l|}{ Gulf Region } \\
\hline Louisiana Gulf ... & 4,255 & 22 & 6,849 & 0 & 11,126 & 5,526 \\
\hline North Texas Gulf... & 97,546 & 34,866 & 2,013 & 0 & 134,425 & 127,062 \\
\hline South Texas Gulf .. & 50,834 & 42,466 & 0 & $\underline{0}$ & 93,300 & 91,173 \\
\hline Subtotal $\ldots \ldots \ldots \ldots$ & 152,635 & 77,354 & 8,862 & 0 & 238,851 & 223,761 \\
\hline \multicolumn{7}{|c|}{ Pacific Region } \\
\hline Columbia River ... & 15 & 0 & 0 & 0 & 15 & 0 \\
\hline Puget Sound.............. & 331 & 1,865 & 0 & 0 & 2,196 & 1,378 \\
\hline California ................. & 1,539 & 0 & $\underline{0}$ & 626 & 2,165 & 1,869 \\
\hline Subtotal ........ & 1,885 & 1,865 & 0 & 626 & 4,376 & 3,247 \\
\hline Total receipts ....... & 154,520 & 79,219 & 8,862 & 626 & 243,227 & 227,008 \\
\hline $\begin{array}{l}\text { Percentage of } \\
\text { total receipts.. }\end{array}$ & 63.5 & 32.6 & 3.6 & 0.3 & 100.0 & \\
\hline
\end{tabular}

a This column reports receipts at elevators in each port area delivered directly from farmers.

Figure 5. Proportion of 1977 sorghum movements to export regions from each originating state.

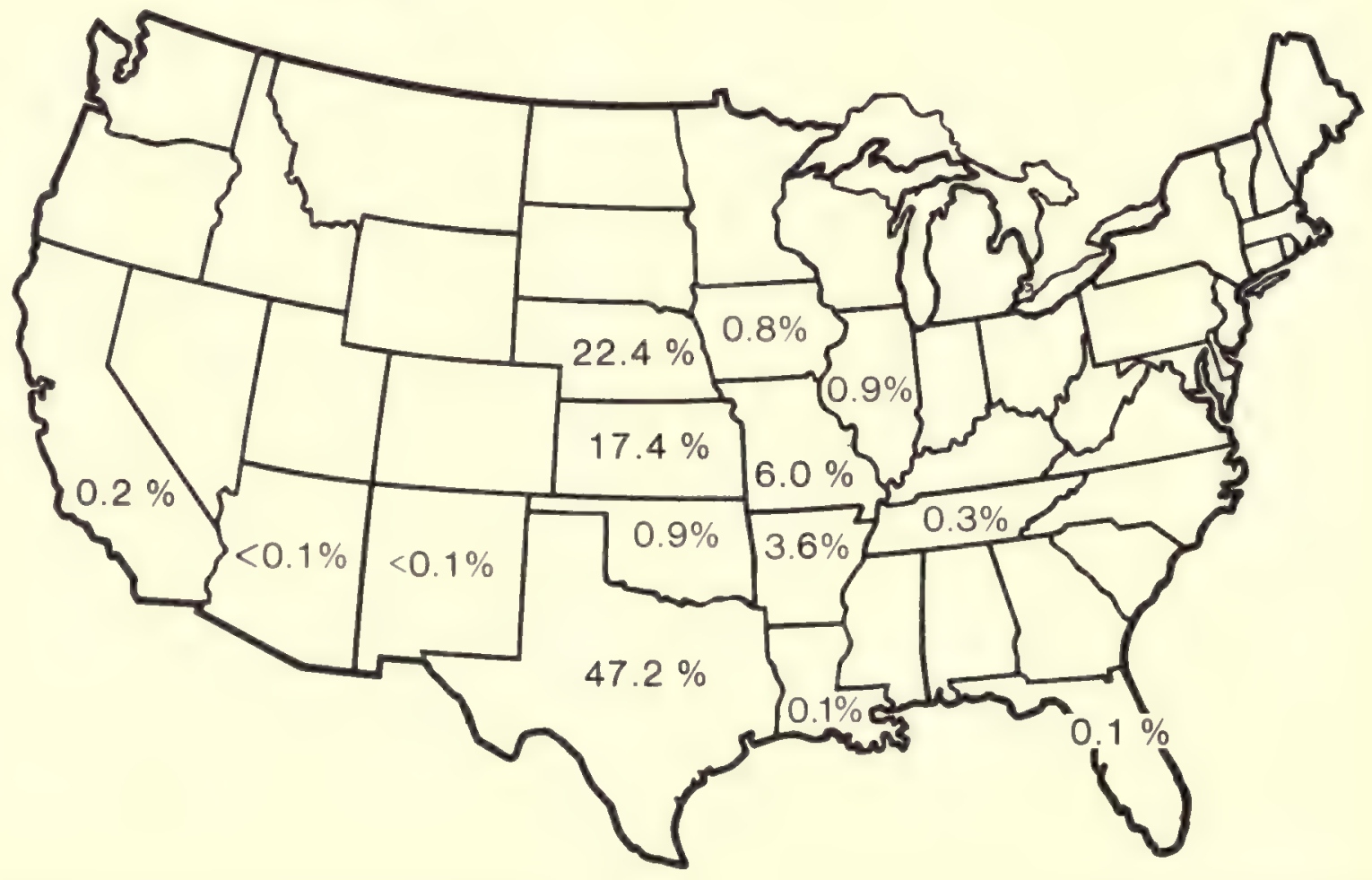




\section{RECEIPTS AND SHIPMENTS BY AREA}

Estimates of the flow of sorghum by each mode of transportation and for every area are presented in Tables 13-115. These estimates represent the most comprehensive and best data available on the volume of sorghum transported between each of the regions of the United States.

A detailed study of the flows will likely lead some readers to the conclusion that there are inefficiencies in the shipment of grain among states. Shipping sorghum in both directions between two states is one example of an apparent inefficiency in the marketing pattern. However, most of the shipments reported in this study reflect sellers' attempts to take advantage of profitable marketing opportunities that occur at a particular moment. It is not possible to provide a rationale for all of the movements without complete knowledge of daily price and transportation relationships. Local supply and demand vary throughout the marketing year, and buyers constantly seek the most economical supply source. Changes in supplies, demands, and transportation costs result in frequent changes in the most profitable shipping pattern.

The availability of storage space at harvest time is also an important factor in determining sorghum shipments. If local storage facilities are filled with wheat when sorghum moves from the farms, country elevators may be forced to ship sorghum to various terminal locations such as Kansas City for storage. If these movements are by rail under transit rates, then this grain is committed to moving to domestic and export points beyond the terminal location. Later in the year, available supplies in the local region may be exhausted, and feed mills and livestock feeders in that area will begin purchasing sorghum from outside sources, reversing the earlier outbound flow. Many other factors, such as the availability of transportation, have a substantial impact on sorghum movements. An inadequate supply of rail cars during periods of peak movement may force sorghum to flow in a pattern that would not otherwise be the most economical. A detailed analysis of the influence of these factors is beyond the scope of this publication. Readers interested in more detailed information about the type of firms involved in sorghum movements and the seasonality of these movements should contact Agri- cultural Experiment Station representatives in the participating states.

Table 12. 1977 Exports of U.S. Sorghum by Export Region and Destination

\begin{tabular}{|c|c|c|c|}
\hline \multirow{2}{*}{ Destination } & \multicolumn{2}{|c|}{ Export regiona } & \multirow{2}{*}{ Total } \\
\hline & Gulf & Pacific & \\
\hline & \multicolumn{3}{|c|}{ thousands of bushels } \\
\hline Belgium .......... & 8,267 & 0 & 8,267 \\
\hline Colombia......... & 3,792 & 0 & 3,792 \\
\hline Cyprus ........... & 550 & 0 & 550 \\
\hline Ecuador .......... & 83 & 0 & 83 \\
\hline Egypt .......... & 993 & 0 & 993 \\
\hline El Salvador........ & 1,173 & 0 & 1,173 \\
\hline Gambia ......... & 130 & 0 & 130 \\
\hline Guatemala ....... & 165 & 0 & 165 \\
\hline Honduras ........ & 442 & 0 & 442 \\
\hline Iran ............. & 1,042 & 0 & 1.042 \\
\hline Israel............ & 26,612 & 0 & 26,612 \\
\hline Italy .............. & 730 & 0 & 730 \\
\hline Ivory Coast ...... & 197 & 0 & 197 \\
\hline Jamaica ......... & 286 & 0 & 286 \\
\hline Japan ............ & 85,356 & 3,247 & 88,603 \\
\hline Lebanon ........ & 173 & 0 & 173 \\
\hline Mexico .......... & 24,615 & 0 & 24,615 \\
\hline Netherlands ...... & 5,288 & 0 & 5,288 \\
\hline Nicaragua ....... & 231 & 0 & 231 \\
\hline Norway.......... & 4,708 & 0 & 4,708 \\
\hline Peru ........... & 2,041 & 0 & 2,041 \\
\hline Poland ............ & 5,786 & 0 & 5,786 \\
\hline Portugal .......... & 18,890 & 0 & 18,890 \\
\hline Romania ........ & 2,545 & 0 & 2,545 \\
\hline Senegal ......... & 1,985 & 0 & 1,985 \\
\hline Spain ........... & 18,080 & 0 & 18,080 \\
\hline United Kingdom .. & 1,590 & 0 & 1,590 \\
\hline Venezuela....... & 8,071 & 0 & 8,071 \\
\hline Total ............ & 223,761 & 3,247 & 227,008 \\
\hline
\end{tabular}

Source: Grain Market News, Agricultural Marketing Service, U.S. Department of Agriculture, Vol. 26, No. 5 (February 3. 1978), pp. 11-15.

- Sorghum was not shipped from the Great Lakes and Atlantic regions during 1977. 
TABLE 13, 1977 SOFGHUM FEEEIFTS FFOM UAFIOUS OFIGINS BY FIFIMS IN AFIEA 2600, ALAEAMA

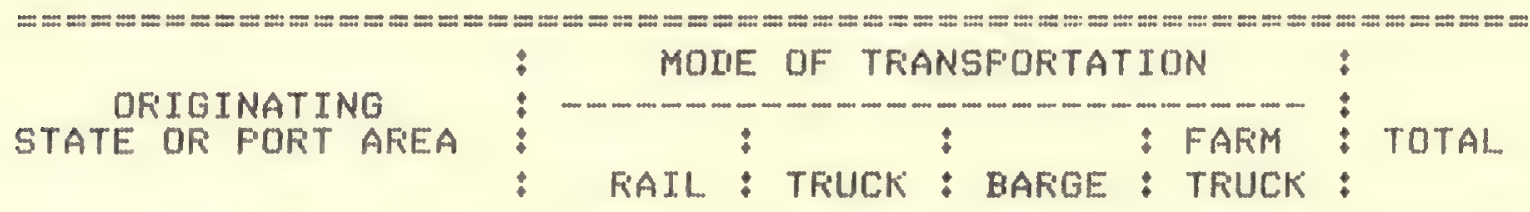

\begin{tabular}{lccccr} 
& \multicolumn{1}{c}{ (THOUSANIS OF } & BUSHELS) \\
2200 ILLINOIS & 203 & 0 & 0 & 0 & 203 \\
2300 KENTUCKY & 0 & 32 & 0 & 0 & 32 \\
2400 TENNESSEE & 0 & 32 & 0 & 0 & 32 \\
2600 ALABAMA & 10 & 47 & 0 & 35 & 92 \\
3505 KANSAS & 30 & 16 & 0 & 0 & 46 \\
TOTAL UDLUME & 243 & 127 & 0 & 35 & 405
\end{tabular}

TARLE 14. 1977 SORGHUM SHIFMENTS TO UARIOUS DESTINATIONS BY FIFMS IN AFEA 2600, ALABAMA

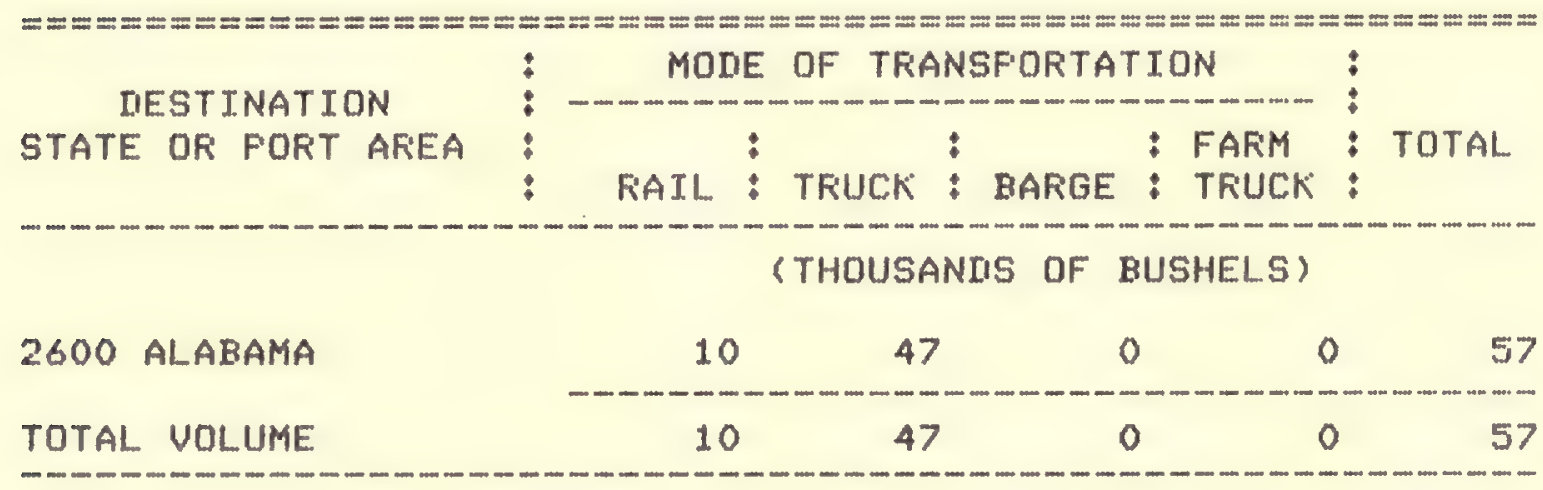


TAELE 15. 1977 SOFGHUM RECEIFTS FFOM VAFIOUS OFIGTNS BY FIFIMS IN AFEA 4401, ARTZONA

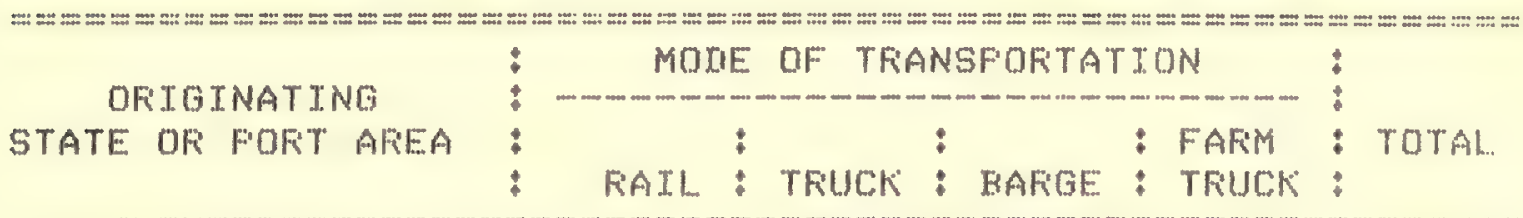

(THOUSANIS OF BUSHELS)

\begin{tabular}{|c|c|c|c|c|c|c|}
\hline 2900 & MISSOUFI & 82 & 0 & 0 & 0 & 82 \\
\hline 3404 & NEBFIASKRA & 438 & 0 & 0 & 0 & 438 \\
\hline 3405 & NEEFASKA & 487 & 308 & 0 & 0 & 795 \\
\hline 3501 & KEANSAS & 173 & 0 & 0 & 0 & 173 \\
\hline 3504 & K゙ANSAS & 3449 & 173 & 0 & 0 & 3622 \\
\hline 3505 & KANSAS & 132 & 67 & 0 & 0 & 199 \\
\hline 3711 & TEXAS & 2050 & 4 & 0 & 0 & 2054 \\
\hline 3712 & TEXAS & 0 & 1256 & 0 & 0 & 1256 \\
\hline 3745 & TEXAS & 68 & 0 & 0 & 0 & 68 \\
\hline 4000 & COLOFIAIIO & 152 & 881 & 0 & 0 & 1033 \\
\hline 4100 & NEW MEXICO & 0 & 180 & 0 & 0 & 180 \\
\hline 4401 & AFIIZONA & 583 & 5360 & 0 & 2033 & 7976 \\
\hline 4402 & ARIZONA & 0 & 1720 & 0 & 591 & 2311 \\
\hline TOTAL & VOLUME & 7614 & 9949 & 0 & 2624 & 20187 \\
\hline
\end{tabular}

TAELE 16. 1977 SOFGHUM SHIFMENTS TO VARTOUS LIESTTNATIONS EY FIFMS IN AREA 440L, AFIZONA

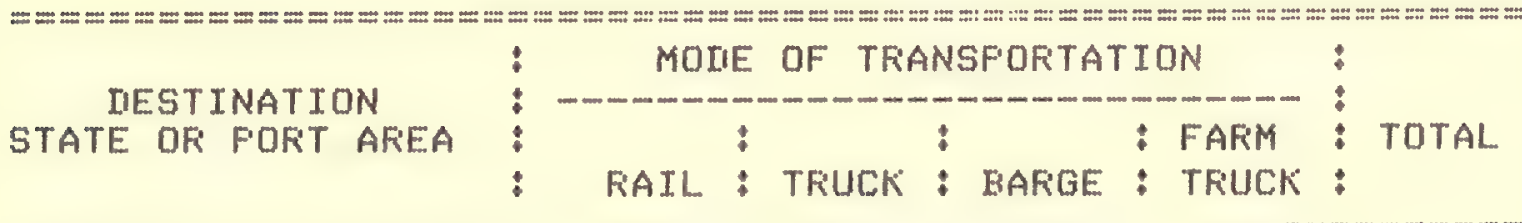

(THOUSANIS OF BUSHELS)

$\begin{array}{llrrrrr}4401 & \text { AFIZZONA } & 583 & 5360 & 0 & 4109 & 10052 \\ 4402 & \text { ARIZONA } & 0 & 450 & 0 & 0 & 450 \\ 4704 \text { CALIFORNIA } & 0 & 71 & 0 & 0 & 71 \\ 7304 & \text { SO. TEXAS GULF } & 94 & 0 & 0 & 0 & 94 \\ \text { TOTAL VOLUME } & 677 & 5881 & 0 & 4109 & 10667\end{array}$


TAELE. 17. 1977 SOFGHUM FECEIFTS FFOM UAFIOUS DFIGINS BY FIFIMS IN AFIEA 4402, AFIZONA

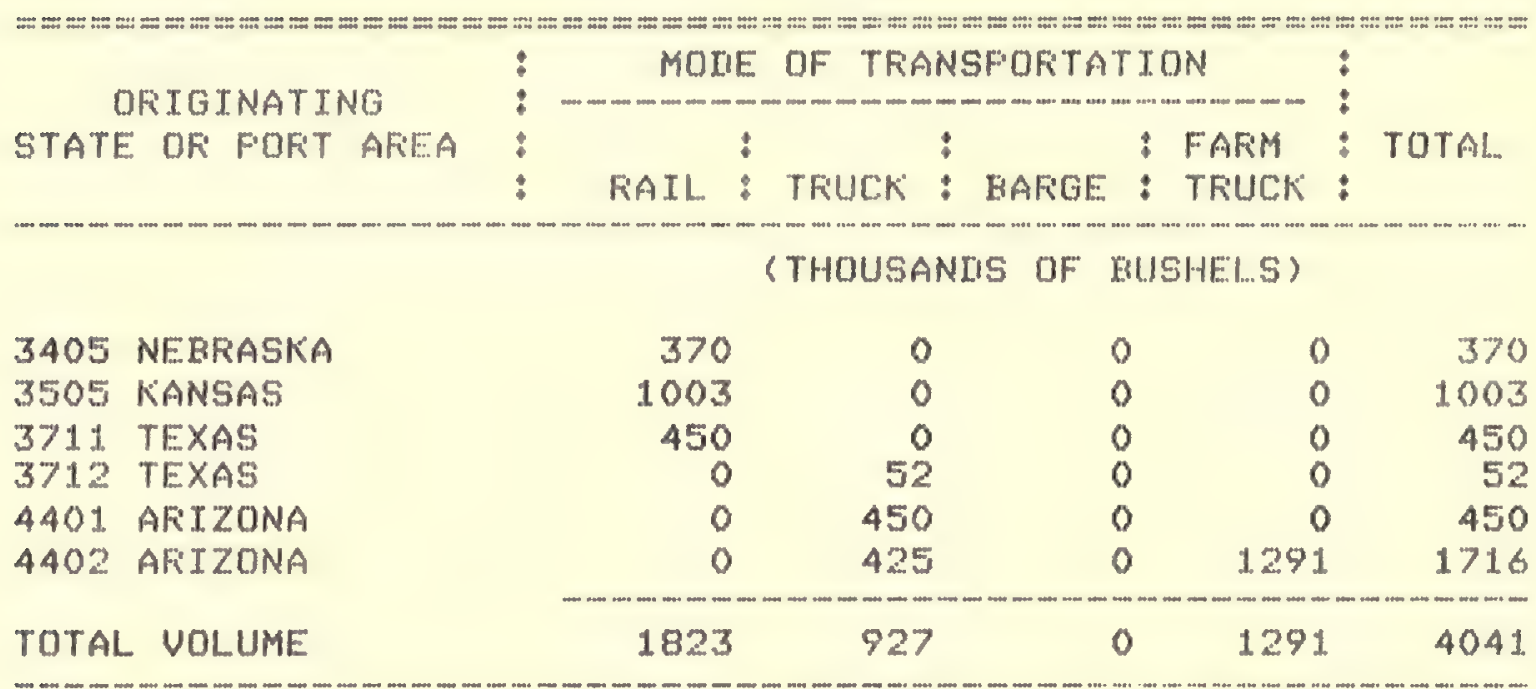

TABLE 18. 1977 SORGHUM SHIFMENTS TO VAFIOUS LESTINATIONS BY FIFIMS IN AFIEA 4402, AFIIZONA

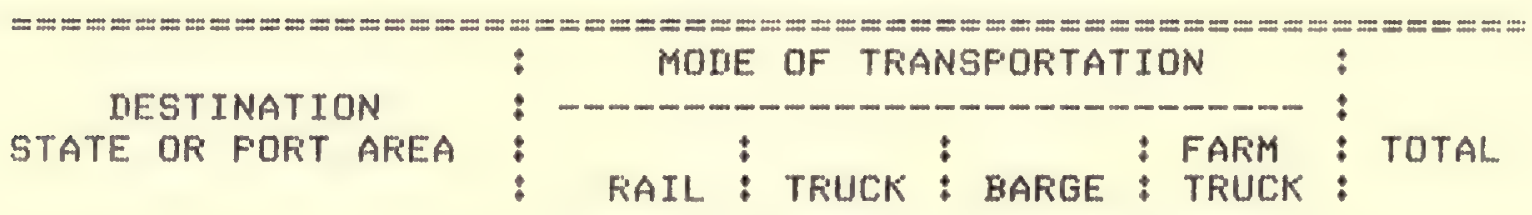

(THOUSANLIS OF BUSHELS)

\begin{tabular}{lccccr}
4401 ARIZONA & 0 & 1720 & 0 & 0 & 1720 \\
4402 ARIZONA & 0 & 425 & 0 & 0 & 425 \\
4403 ARIZONA & 0 & 110 & 0 & 0 & 110 \\
& 0 & 2255 & 0 & 0 & 2255 \\
\hline
\end{tabular}


TABLE 19. 1977 SORGHUM FECEIFTS FFOM UARIOUS OFIGTNG BY FIRMS IN AFIEA 4403 , ARTZONA

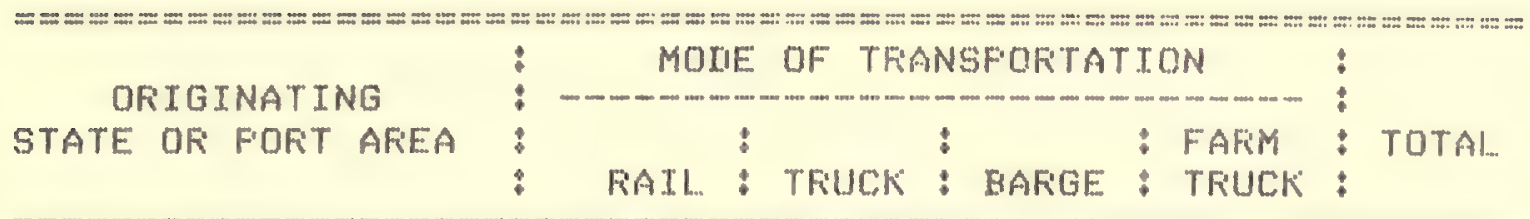

(THOUSANIIS OF EUSHELS)

$\begin{array}{lrrrrr}3505 \text { KANSAS } & 198 & 0 & 0 & 0 & 193 \\ 3711 \text { TEXAS } & 256 & 0 & 0 & 0 & 256 \\ 3712 \text { TEXAS } & 14 & 3 & 0 & 0 & 17 \\ 3745 \text { TEXAS } & 12 & 0 & 0 & 0 & 12 \\ 4100 \text { NEW MEXICO } & 290 & 10 & 0 & 0 & 300 \\ 4402 \text { AFIZONA } & 0 & 110 & 0 & 261 & 371 \\ 4403 \text { ARIZONA } & 0 & 0 & 0 & 350 & 350 \\ \text { TOTAL VOLUME } & 770 & 123 & 0 & 611 & 1504\end{array}$

TABLE 20, 1977 SOFGHUM FECEIFTS FFOM UARTOUS OFIGINS BY FIFMS IN AFEA 3005, AFIKANSAS

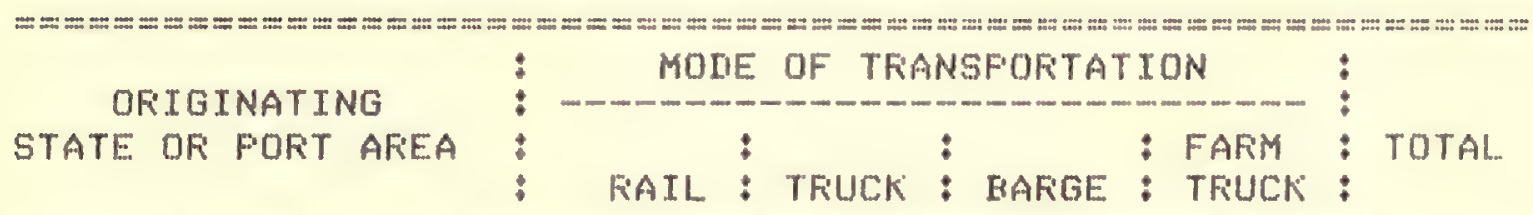

\begin{tabular}{lrrrrr} 
& \multicolumn{7}{c}{ (THOUSANIS } & OF & BUSHELS) \\
2200 ILLINOIS & 146 & 0 & 0 & 0 & 1.46 \\
2900 MISSOUFI & 812 & 27 & 0 & 0 & 839 \\
3005 ARKANSAS & 0 & 0 & 0 & 12 & 12 \\
3038 ARKANSAS & 0 & 1297 & 0 & 378 & 1675 \\
3405 NEBRASKA & 0 & 27 & 0 & 0 & 27 \\
3503 KANSAS & 688 & 0 & 0 & 0 & 688 \\
3505 KANSAS & 137 & 0 & 0 & 0 & 137 \\
TOTAL VOLUME & 1783 & 1351 & 0 & 390 & 3524
\end{tabular}


TAELE 21. 1977 SORGHUM FEECEIFTS FROM UARIOUS ORIGINS BY FIFMS IN AFEA 3016, AFIKANSAS

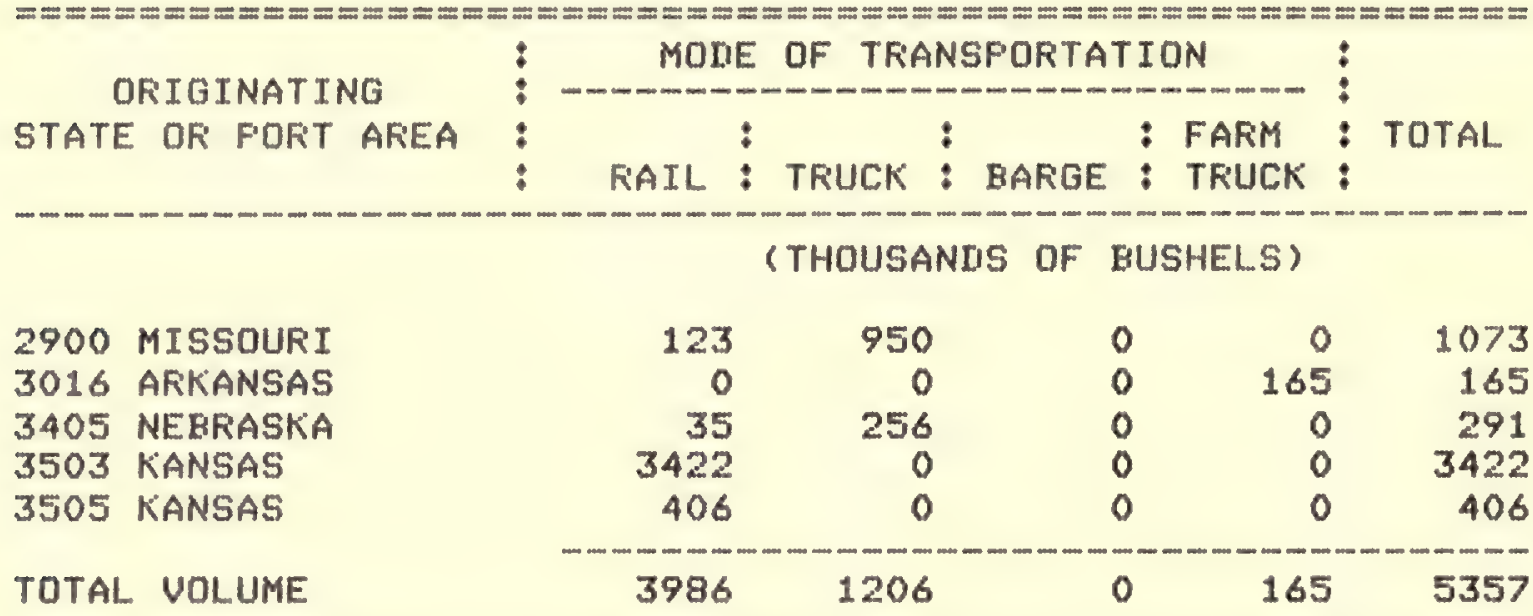

TABLE 22. 1977 SOFGHUM RECEIFTS FROM UARIOUS ORIGINS BY FIFMS IN AREA 3017, AFKKANSAS

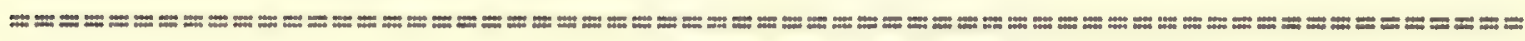

ORIGINATING

STATE OR PORT AREA

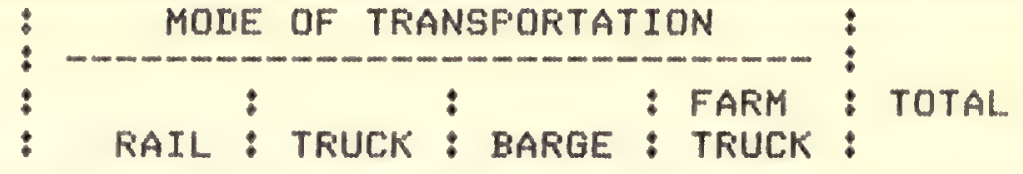

(THOUSANIS OF BUSHELS)

\begin{tabular}{|c|c|c|c|c|}
\hline 2800 IOWA & 71 & 0 & 0 & 0 \\
\hline 2900 MISSOURI & 700 & 0 & 0 & 0 \\
\hline 3038 ARKANSAS & 0 & 672 & 0 & 0 \\
\hline 3505 KANSAS & 221 & 0 & 0 & 0 \\
\hline AL VOLUME & 992 & 672 & 0 & 0 \\
\hline
\end{tabular}

TAELE 23. 1977 SORGHUM RECEIFTS FROM UARIOUS ORIGINS BY FIFIMS IN AREA 3038, AFKKANSAS

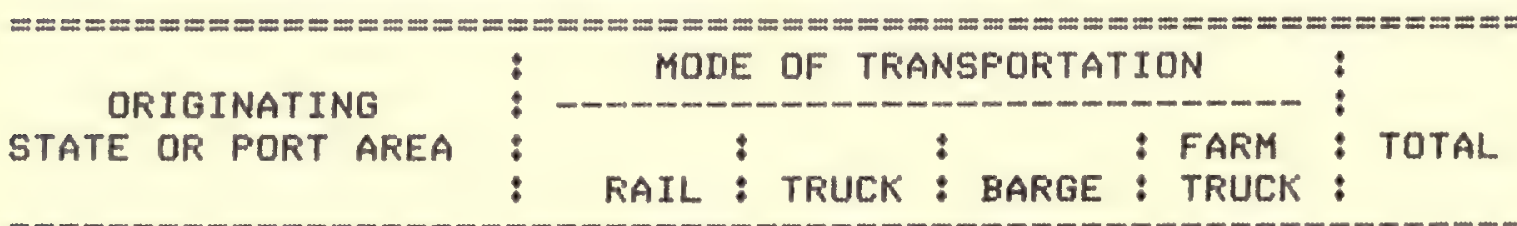

(THOUSANIS OF BUSHELS)

$\begin{array}{lcccrr}2900 \text { MISSOUFI } & 0 & 291 & 0 & 0 & 291 \\ 3038 \text { ARKANSAS } & 0 & 8552 & 0 & 10876 & 19428 \\ 3505 \text { KANSAS } & 133 & 0 & 0 & 0 & 133 \\ \text { TOTAL UOLUME } & -133 & 8843 & 0 & 10876 & 19852\end{array}$


TABLE 24, 1977 SOFGHUM SHIFMENTS TO VAFIOUS IESTINATIONS EY FIFMS IN AREA 3038, ARK

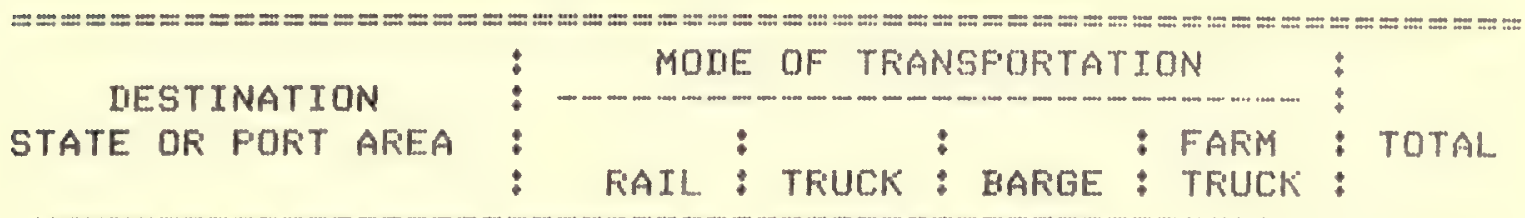

(THOUSANIIS OF RUSHELS)

\begin{tabular}{|c|c|c|c|c|c|}
\hline 2400 TENNESSEE & 675 & 160 & 0 & 0 & 835 \\
\hline 2500 MISSISSIFPI & 0 & 97 & 0 & 0 & 97 \\
\hline 2900 MISSOURI & 0 & 127 & 0 & 0 & 127 \\
\hline 3005 ARKANSAS & 0 & 1297 & 0 & 0 & 1297 \\
\hline 3017 ARKANSAS & 0 & 672 & 0 & 18 & 690 \\
\hline 3038 AFKANSAS & 0 & 8552 & 0 & 60 & 8612 \\
\hline 3100 LOUISIANA & 0 & 2 & 0 & 0 & \\
\hline 3745 TEXAS & 298 & 178 & 0 & 0 & 476 \\
\hline $\begin{array}{l}7302 \text { LOUISIANA GULF } \\
7303 \text { NO. TEXAS GULF }\end{array}$ & $\begin{array}{r}3965 \\
900\end{array}$ & $\begin{array}{l}0 \\
0\end{array}$ & $\begin{array}{r}2010 \\
0\end{array}$ & $\begin{array}{l}0 \\
0\end{array}$ & $\begin{array}{r}5975 \\
900\end{array}$ \\
\hline 7402 FUGET SOUNI & 0 & 1865 & 0 & 0 & 1865 \\
\hline OTAL. VOLUME & 5838 & 12950 & 2010 & 78 & .087 \\
\hline
\end{tabular}

TAELE 25. 1977 SOFGHUM FECEIFTS FFOM VARIOUS ORIGINS RY FIFMS IN AFEA 4701, CALIFOFNIA

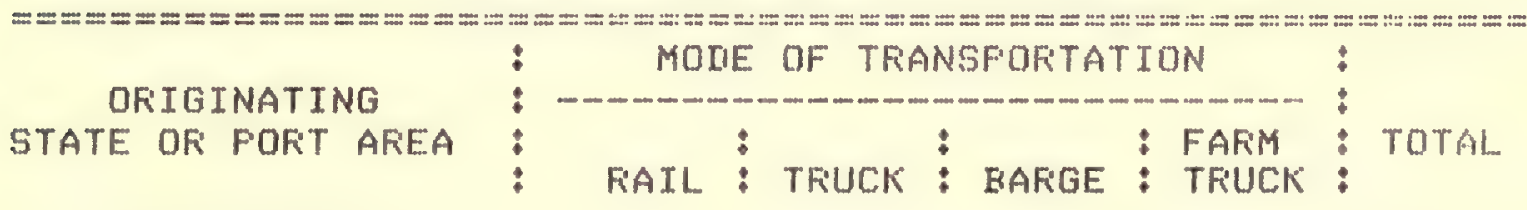

(THOUSANDS DF BUSHELS)

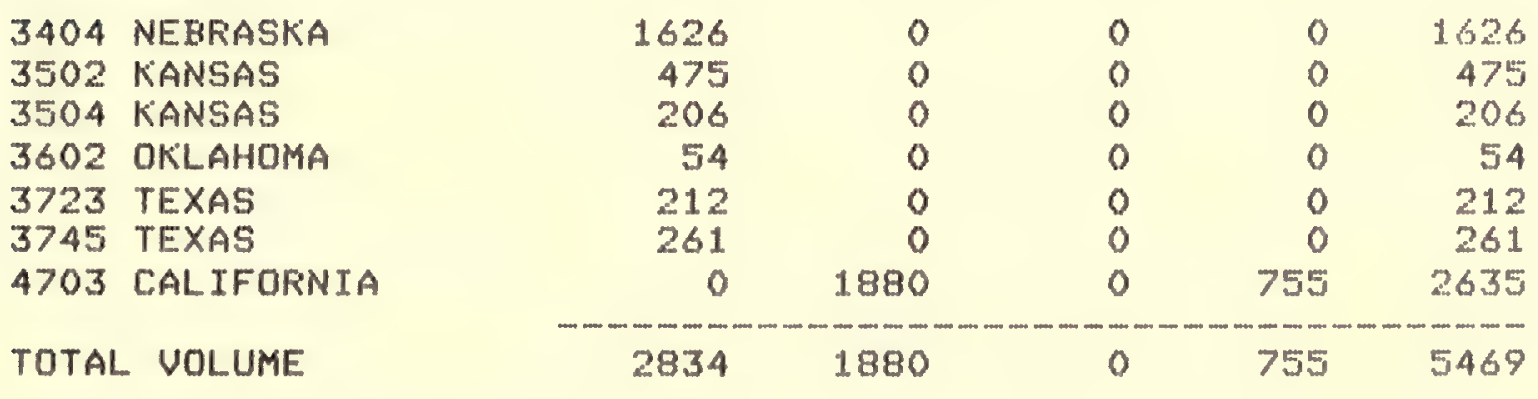


TABLE 26. 1977 SOFGHUM RECEIFTS FROM UARIOUS ORIGINS BY FIFIMS IN AREA 4703 , CALIFOFINTA

\begin{tabular}{|c|c|c|c|c|c|c|c|c|c|}
\hline \multirow{3}{*}{\multicolumn{2}{|c|}{$\begin{array}{l}\text { OFIGINATING } \\
\text { STATE OF FORT AFEA }\end{array}$}} & \multirow{3}{*}{$\vdots$} & MONE OF & E OF TRA & \multicolumn{4}{|c|}{ TRANSFOFT TATION } & \multirow{3}{*}{ TOTAL } \\
\hline & & & & : & $:$ & : & FAFIM & \multirow{2}{*}{$\vdots$} & \\
\hline & & & RAIL & : TRULK & : BAFGE & : & TRUCK & & \\
\hline & & & \multicolumn{3}{|c|}{ (THOUSANIIS OF } & \multicolumn{3}{|c|}{ RUSHELS) } & \\
\hline 3405 & NEBKASKKA & & 637 & $\varepsilon$ & 3 & 0 & & 0 & 645 \\
\hline 3502 & KANSAS & & 0 & 147 & & 0 & & 0 & 147 \\
\hline 3504 & KANSAS & & 23 & 0 & 0 & 0 & & 0 & 23 \\
\hline 3712 & TEXAS & & 0 & $\varepsilon$ & 3 & 0 & & 0 & 8 \\
\hline 3745 & TEXAS & & 15 & 0 & 0 & 0 & & 0 & 15 \\
\hline 4703 & CAL IFOFINIA & & 0 & 310 & & 0 & 5093 & & 5403 \\
\hline TOTAL & VOLUME & & 675 & 473 & & 0 & 5093 & & 6241 \\
\hline
\end{tabular}

TABLE 27. 1977 SORGHUM SHIFMENTS TO UAFIOUS RESTINATIONS BY FIFMS IN AREA 4703 , CALIFOFNIA

플

DESTINATION

STATE OR FOFT AREA

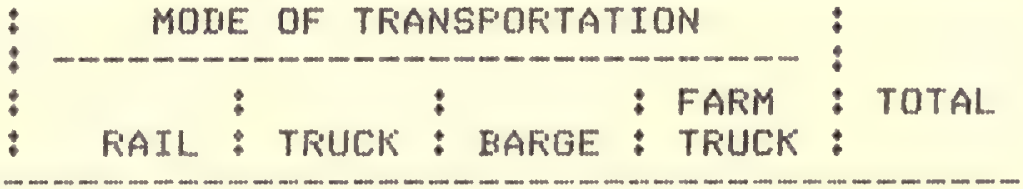

(THOUSANRS OF EUSHELS)

$\begin{array}{lcccccr}4701 & \text { CALIFOFNIA } & 0 & 1880 & 0 & 0 & 1880 \\ 4703 & \text { CALIFOFNIA } & 0 & 310 & 0 & 0 & 310 \\ 4704 \text { CALIFORNIA } & 1543 & 126 & 0 & 0 & 1669 \\ \text { TOTAL VOLUME } & -1543 & 2316 & 0 & 0 & 3859\end{array}$


TABLE 28. 1977 SOFGHUM RECEIFTS FFOM VAFIOUS OFITGINS BY FIFIS IN AREA 4704, CALIFOFINTA

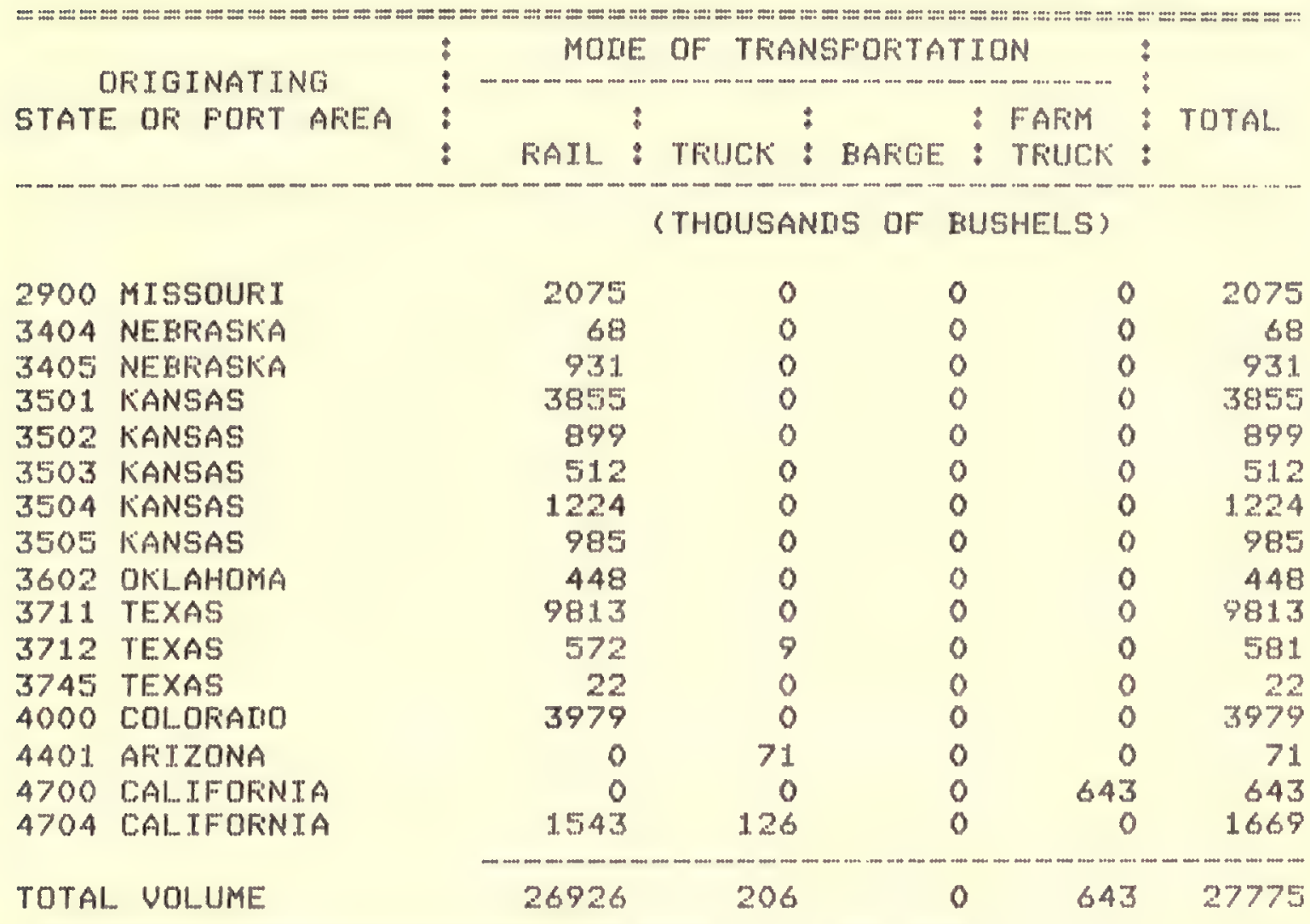

TABLE 29. 1977 SOFGHUM RECEIFTS FROM UARIOUS OFIGINS BY FIFIMS IN AFIEA 4000 , COLOFIALO

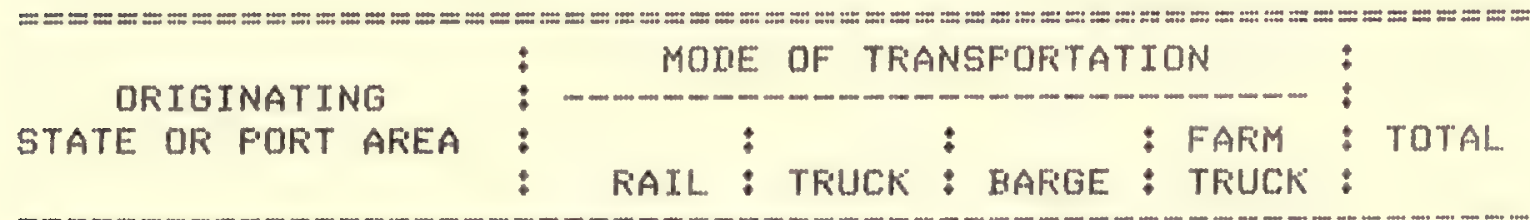

(THOUSANIS OF BUSHELS)

\begin{tabular}{lcccccr}
3401 & NEERASKA & 60 & 97 & 0 & 0 & 157 \\
3403 NEBRASKA & 7 & 0 & 0 & 0 & 7 \\
3404 & NEBRASKA & 981 & 0 & 0 & 0 & 981 \\
3405 NEBFASKA & 842 & 157 & 0 & 0 & 999 \\
3501 & KANSAS & 95 & 622 & 0 & 0 & 717 \\
3505 KANSAS & 673 & 0 & 0 & 0 & 673 \\
4000 COLORAID & 0 & 0 & 0 & 3650 & 3650 \\
TOTAL UOLUME & 2658 & 876 & 0 & 3650 & 7184 \\
\hline
\end{tabular}


TAELE 30. 1977 SOFGHUM SHIFMENTS TO VARIOUS IIESTTNATTONS EY FIFIMS IN AFEA 4000 , COLOFIAIO

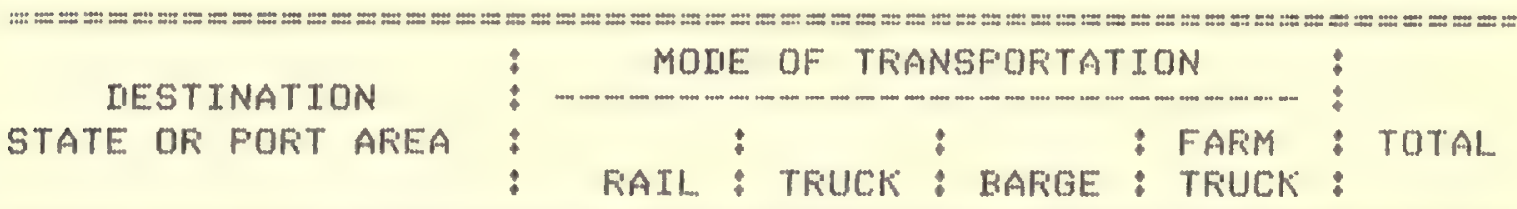

(THOUSANLS OF BUSHELS)

3502 KANGAS

3503 KANSAS

3711 TEXAS

3712 TEXAS

3745 TEXAS

4401 AFIIZONA

4704 CALIFOFNIA

TOTAL VOL.UME

\begin{tabular}{rrrrr}
18 & 0 & 0 & 0 & 18 \\
8 & 18 & 0 & 0 & 26 \\
1355 & 28 & 0 & 0 & 1383 \\
244 & 0 & 0 & 0 & 244 \\
5 & 0 & 0 & 0 & 5 \\
152 & 881 & 0 & 0 & 1033 \\
3979 & 0 & 0 & 0 & 3979 \\
\hline 5761 & 927 & 0 & 0 & 6688
\end{tabular}

TABLE 31. 1977 SOFGHUM FECEIFTS FFOM UAFIDUS OFIGTNS BY FIFMS IN AFEA 600, CONNECTICUT

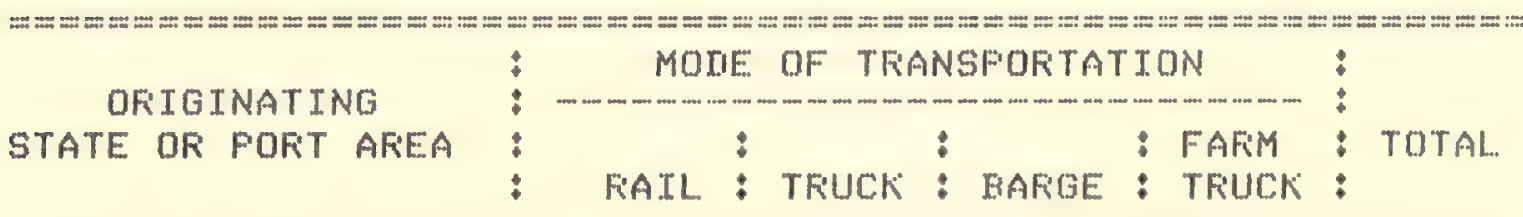

(THOUSANIS OF BUSHELS)

2200 ILLINOIS

167

0

167

TOTAL VOLUME

167

0

0

167

TOTAL UOLUME

1.67

0

0

0

167

TABLE 32, 1977 SOFGHUM FECEIFTS FFOM VAFTOUS ORIGINS EY FIFIMS IN AFIEA 1700 , FLOFIIIA

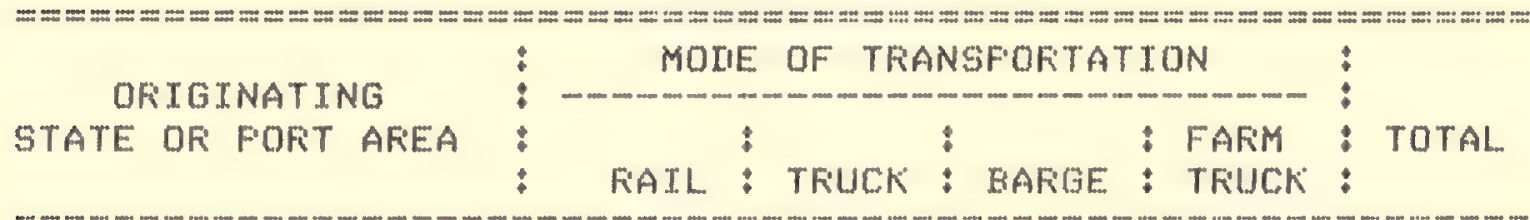

(THDUSANIS OF EUSHELS)

$\begin{array}{lccccc}1700 \text { FLORIIIA } & 0 & 76 & 0 & 179 & 255 \\ \text { TOTAL VOLUME } & 0 & 76 & 0 & 179 & 255\end{array}$


TAELE 33, 1977 SOFGHUM SHIFMENTS TO VAFIOUS IIESTINATIONS BY FIFMS IN AREA 1700 , FLOFIIIA

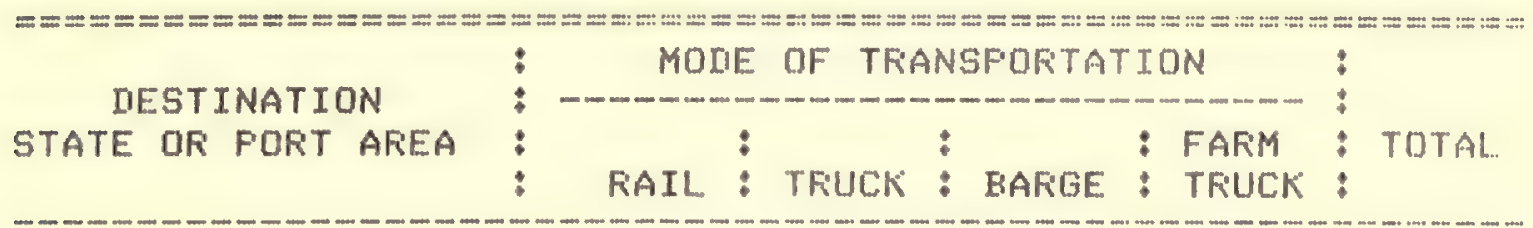

(THOUSANIS OF RUSHELS)

\begin{tabular}{|c|c|c|c|c|c|c|}
\hline 1700 FLORIDA & & 0 & 76 & 0 & 0 & 76 \\
\hline 7302 LOUISIANA & GULF & 0 & 0 & 246 & 0 & 246 \\
\hline TOTAL VOLUME & & 0 & 76 & 246 & 0 & \\
\hline
\end{tabular}

TABLE 34. 1977 SOFGHUM FIECEIFTS FFOM UARIOUS OFIGINS EY FIRMS IN AFEA 1600, GEOFGIA

\begin{tabular}{|c|c|c|c|c|c|c|c|c|}
\hline ORIGINATING & $\vdots$ & MaI & IIE OF TFi & ANSF'OFTA & TIC & & $\vdots$ & \multirow[b]{2}{*}{ TOTAL } \\
\hline STATE DR PORT AREA & : & FAIL & : TRUCK & : HARGE & : & $\begin{array}{l}\text { FAFIM } \\
\text { TRUCK }\end{array}$ & $\vdots$ & \\
\hline & & \multicolumn{6}{|c|}{ (THOUSANIS OF BUSHELS) } & \\
\hline 1600 GEORGIA & & & $5:$ & & 0 & & 1 & 1.13 \\
\hline TOTAL VOLUME & & & $5:$ & & 0 & & 61 & 113 \\
\hline
\end{tabular}

TABLE 35. 1977 SOFGHUM SHIFMENTS TO UARIQUS IIESTINATIONS EY FIFIMS IN AFEA 1600, GEORGIA

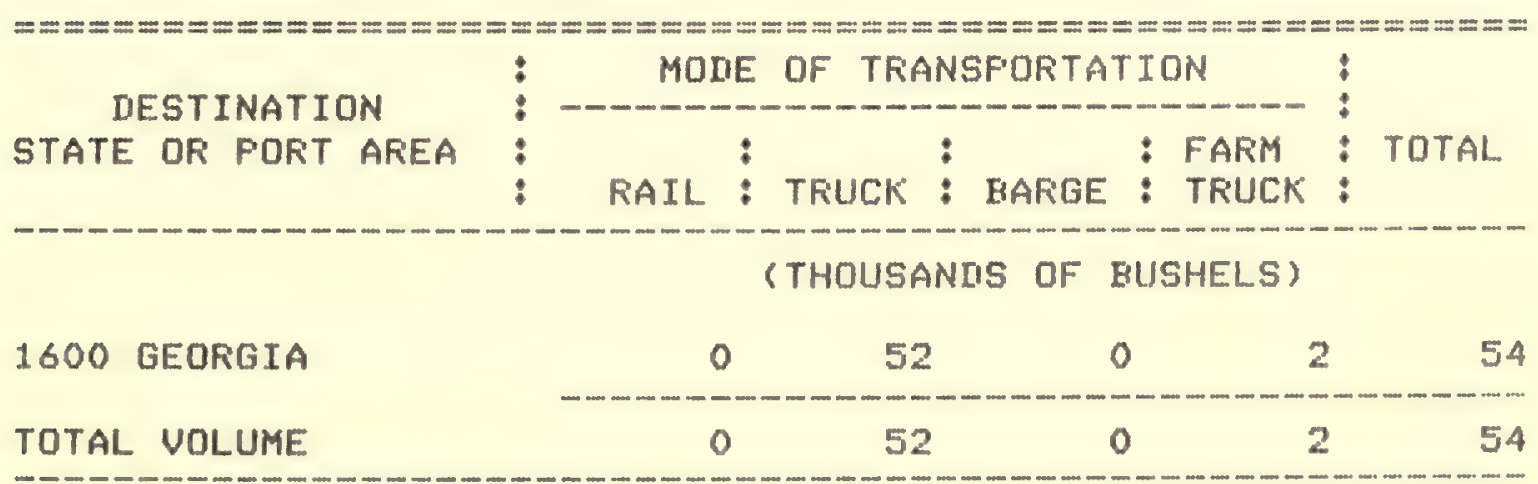


TABLE 36. 1977 SOFGHUM FECEIFTS FROM UARTOUS DFIGINS BY FIFMS IN AFEA 2200, TLL.TNOTS

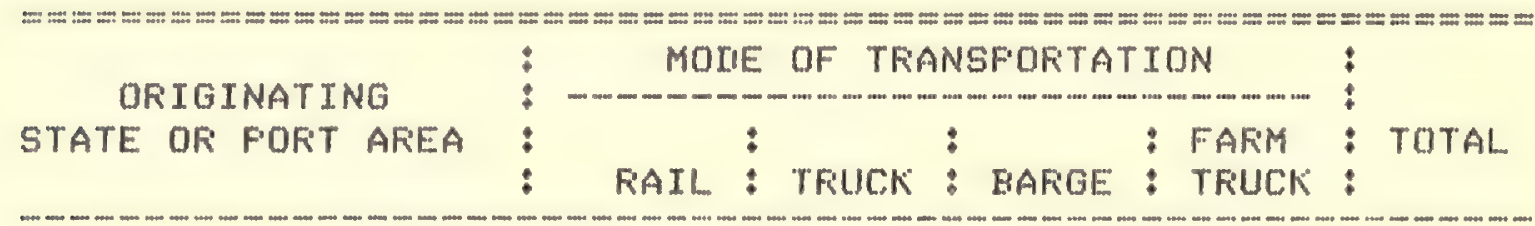

(THOUSANIIS OF BUSHELS)

$\begin{array}{llcrrrr}2200 & \text { ILLINOIS } & 0 & 226 & 0 & 1525 & 1751 \\ 2300 \text { KENTUCKY } & 0 & 0 & 0 & 735 & 735 \\ 2900 \text { MISSOURI } & 0 & 0 & 0 & 392 & 392 \\ 3405 \text { NEBRASKA } & 0 & 214 & 0 & 0 & 214 \\ 3503 \text { KNANSAS } & 83 & 0 & 0 & 0 & 83 \\ \text { TOTAL VOLUME } & 83 & 440 & 0 & 2652 & 3175\end{array}$

TAELE 37. 1977 SORGHUM SHIFMENTS TO VARIOUS IESTINATIONS BY FIFMS IN AFEA 2200, ILLINOIS

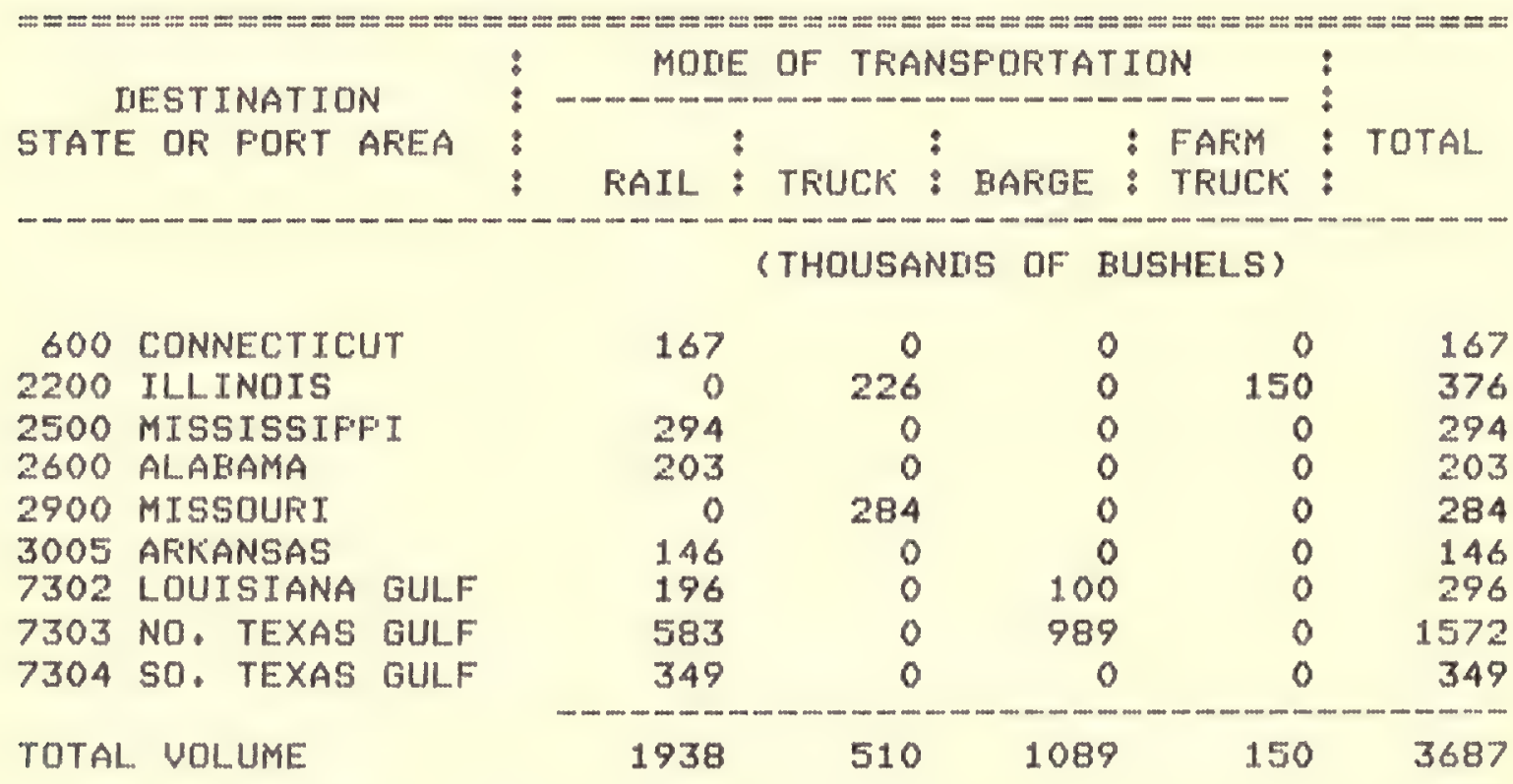


TABLE 38. 1977 SOFGHUM FECEIFTS FROM UAFIOUS OFIGINS BY FIFIMS IN AFEA 2800, IOWA

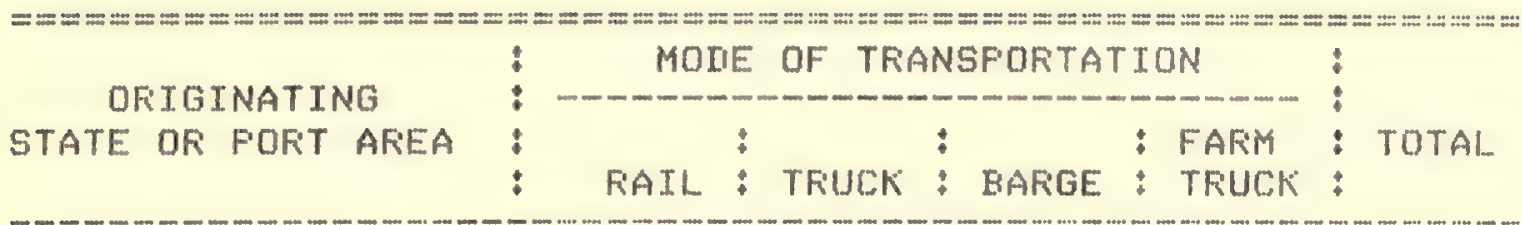

(THOUSANIS OF BUSHELS)

$\begin{array}{llcccrr}2800 & \text { IOWA } & 0 & 183 & 0 & 162 & 345 \\ 3403 \text { NEBRASKA } & 64 & 16 & 0 & 0 & 80 \\ 3405 \text { NEERASKA } & 69 & 80 & 0 & 0 & 149 \\ \text { TOTAL VOLUME } & 133 & 279 & 0 & 162 & 574\end{array}$

TABLE 39. 1977 SORGHUM SHIFMENTS TO UAFIOUS IIESTINATIONS BY FIFMS IN AFEA 2800, IOWA

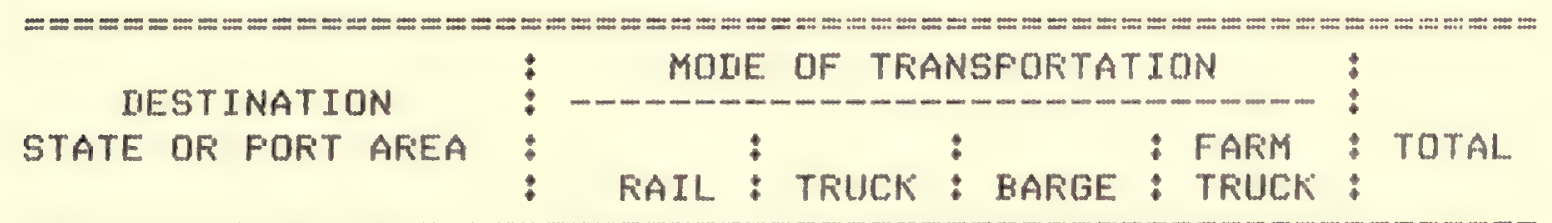

\begin{tabular}{llcccr} 
& \multicolumn{7}{c}{ (THOUSANIS OF BUSHELS) } \\
2500 MISSISSIFPI & 0 & 220 & 0 & 0 & 220 \\
2800 IOWA & 0 & 183 & 0 & 0 & 183 \\
2900 MISSOURI & 28 & 0 & 0 & 0 & 28 \\
3017 ARKANSAS & 71 & 0 & 0 & 0 & 71 \\
3405 NEBFASKA & 14 & 19 & 0 & 0 & 33 \\
3503 KANSAS & 0 & 19 & 0 & 0 & 19 \\
7302 LOUISIANA GULF & 94 & 0 & 0 & 0 & 94 \\
7303 NO. TEXAS GULF & 1644 & 0 & 0 & 0 & 1644 \\
7304 SO. TEXAS GULF & 203 & 0 & 0 & 0 & 203 \\
TOTAL UOLUME & 2054 & 441 & 0 & 0 & 2495 \\
\hline
\end{tabular}


TABLE 40, 1977 SORGHUM RECEIFTS FROM VARIOUS ORIGINS BY FIRMS IN AREA 3500, KANSAS

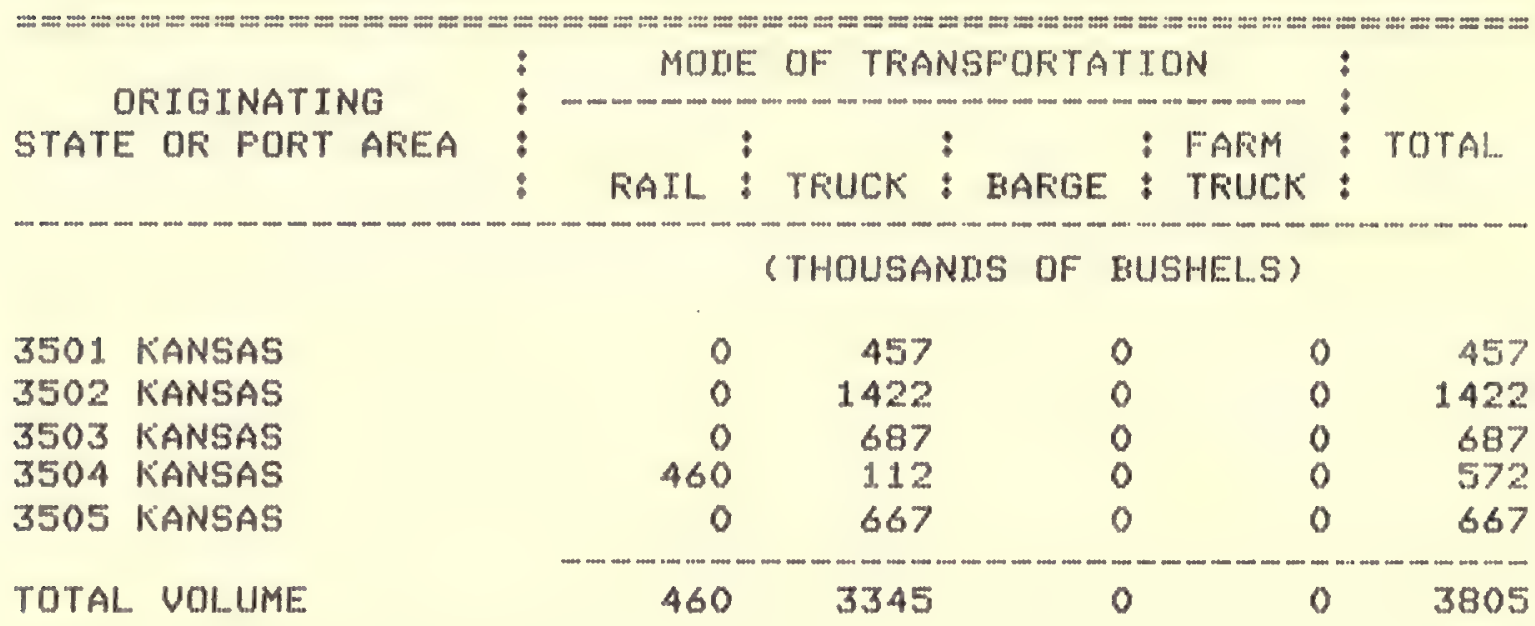

TABLE 41. 1977 SORGHUM RECEIFTS FFOM UAFIOUS ORIGINS BY FIRMS IN AFEA 3501, KANSAS

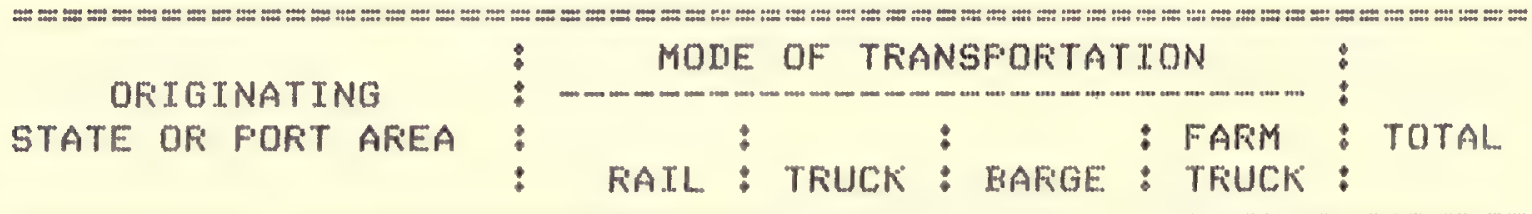

(THOUSANIS OF BUSHELS)

$\begin{array}{llcccc}3501 \text { KANSAS } & 0 & 398 & 0 & 47297 & 47695 \\ \text { TOTAL VOLUME } & 0 & 398 & 0 & 47297 & 47695\end{array}$


TABLE 42. 1977 SORGHUM SHIPMENTS TO VAFIOUS DESTINATIONS BY FIRMS IN AREA 3501, KANSAS

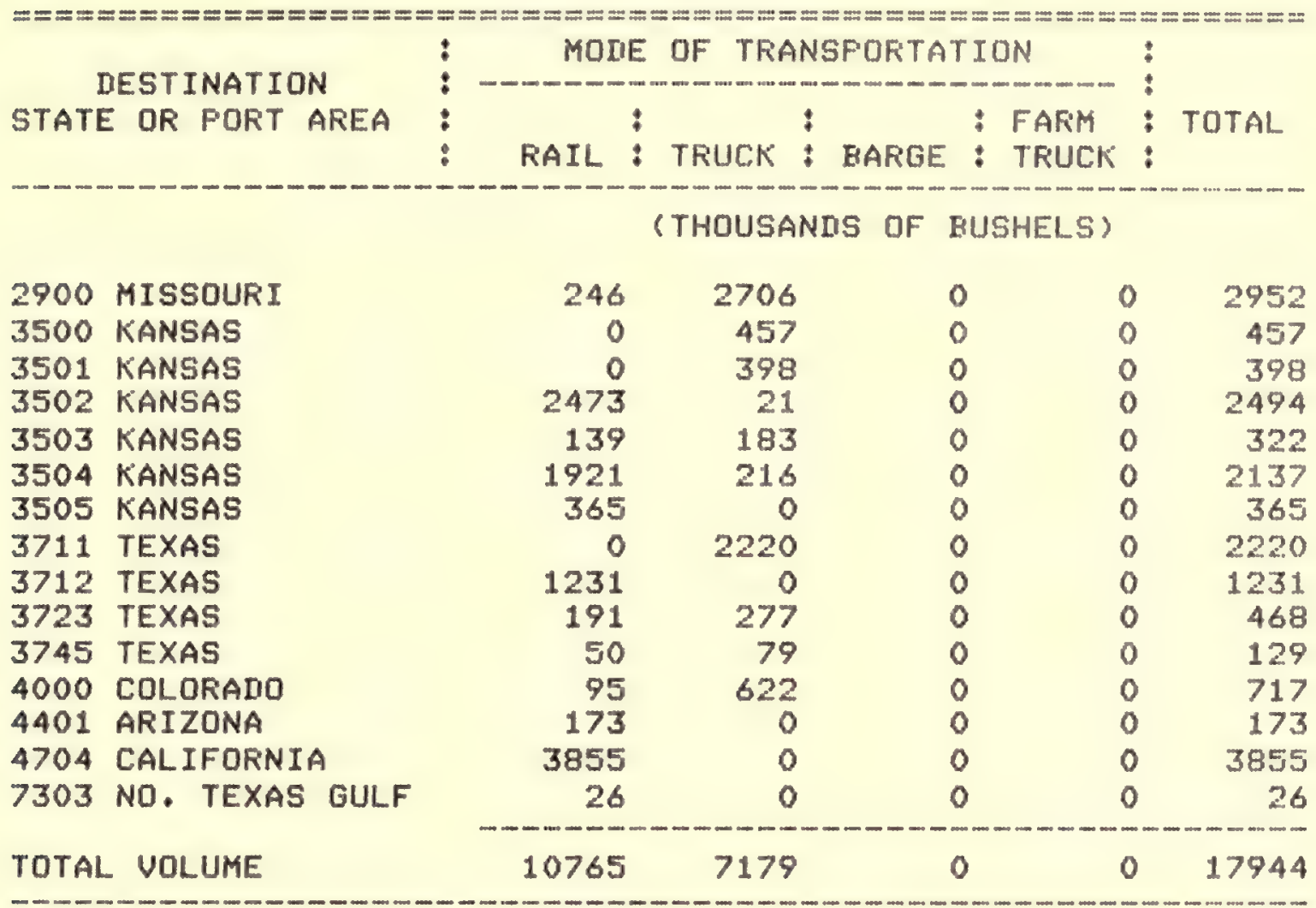

TAELE 43. 1977 SORGHUM RECEIFTS FFOM UARIOUS ORIGINS BY FIRMS IN AFEA 3502, KANSAS

\begin{tabular}{|c|c|c|c|c|c|c|c|c|c|c|}
\hline \multicolumn{3}{|c|}{ ORIGINATING } & \multirow{3}{*}{$\vdots$} & \multicolumn{5}{|c|}{ MODE OF TRANSFOFTATION } & $\vdots$ & \multirow{3}{*}{ TOTAL } \\
\hline STATE & OR PORT & AREA & & & $:$ & : & $:$ & FARM & : & \\
\hline & & & & RAIL & * TRUCK & : EARGE & $:$ & TFUUCK & : & \\
\hline & & & & \multicolumn{3}{|c|}{ (THOUSANIIS OF } & \multicolumn{3}{|c|}{ BUSHELS) } & \\
\hline 2900 & MISSOURI & & & 73 & 0 & & 0 & 0 & 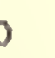 & 73 \\
\hline 3401 & NEBRASKA & & & 123 & 0 & & 0 & 0 & 0 & 123 \\
\hline 3402 & NEBRASKA & & & 194 & 0 & & 0 & 0 & 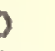 & 194 \\
\hline 3404 & NEBRASKA & & & 117 & 32 & & 0 & 171 & & 320 \\
\hline 3405 & NEBRASKA & & & 1303 & 202 & & 0 & 0 & 0 & 1505 \\
\hline 3501 & KANSAS & & & 2473 & 21 & & 0 & 0 & 0 & 2494 \\
\hline 3502 & KANSAS & & & 2451 & 3101 & & 0 & 50941 & & 56493 \\
\hline 3503 & KANSAS & & & 1644 & 105 & & 0 & 0 & 0 & 1749 \\
\hline $\begin{array}{l}3504 \\
3505\end{array}$ & $\begin{array}{l}\text { KANSAS } \\
\text { KANSAS }\end{array}$ & & & $\begin{array}{r}146 \\
1261\end{array}$ & $\begin{array}{r}0 \\
12\end{array}$ & & $\begin{array}{l}0 \\
0\end{array}$ & $\stackrel{0}{0}$ & 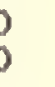 & $\begin{array}{r}146 \\
1273\end{array}$ \\
\hline 3602 & OKLAHOMA & & & 71 & 0 & & 0 & 0 & 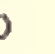 & 71 \\
\hline 4000 & COLORADO & & & 18 & 0 & & 0 & 0 & 0 & 18 \\
\hline TOTAL & VOLUME & & & 9874 & 3473 & & 0 & 51112 & & 64459 \\
\hline
\end{tabular}


TAELE 44. 1977 SOFGHUM SHIFMENTS TO VARIOUS IESTINATIONS BY FIFMS IN AFEA 3502, KANSAS

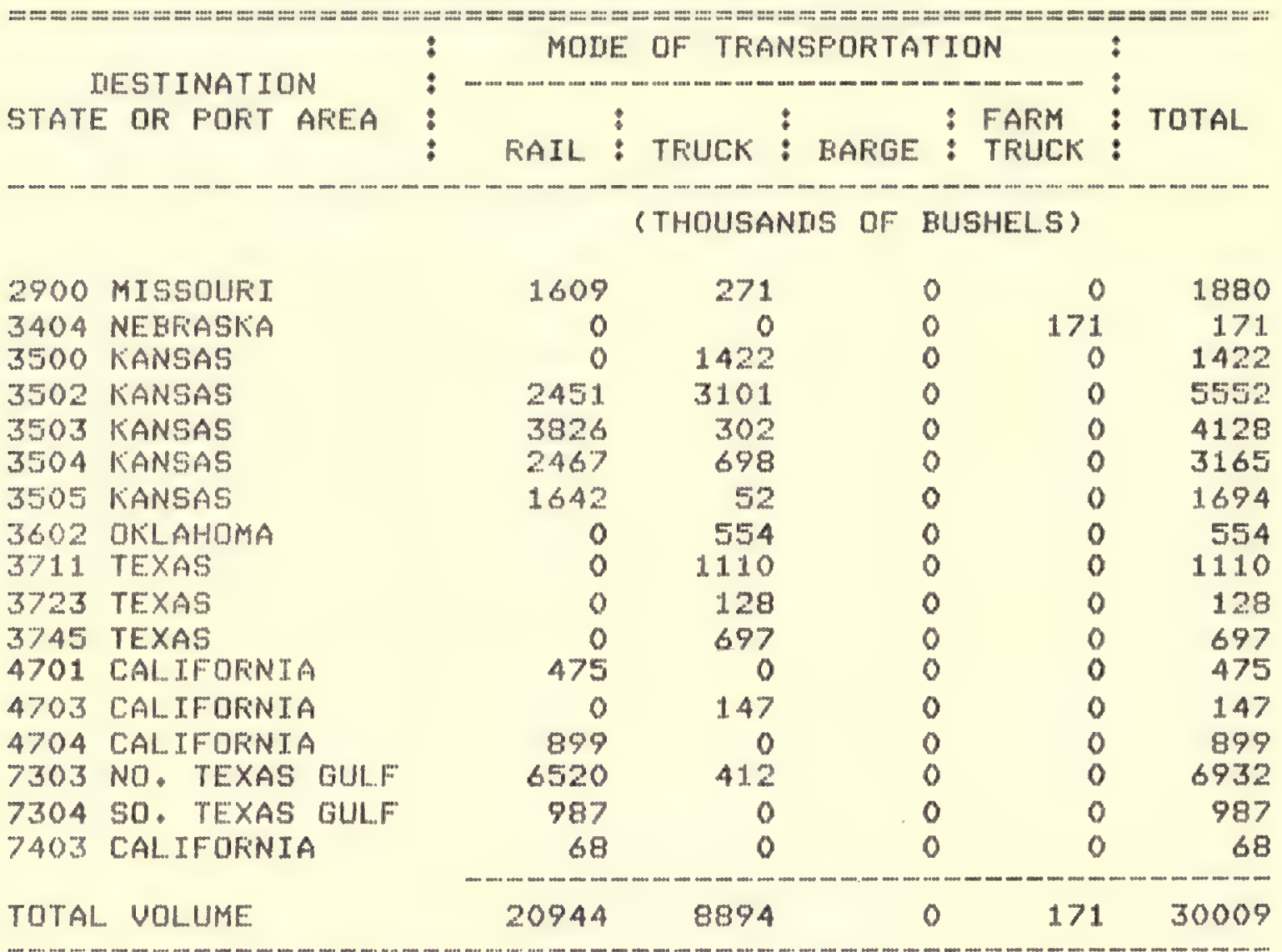

TAELE 45. 1977 SORGHUM RECEIFTS FFOM UAFIOUS ORIGINS BY FIFIMS IN AFEA 3503, KANSAS

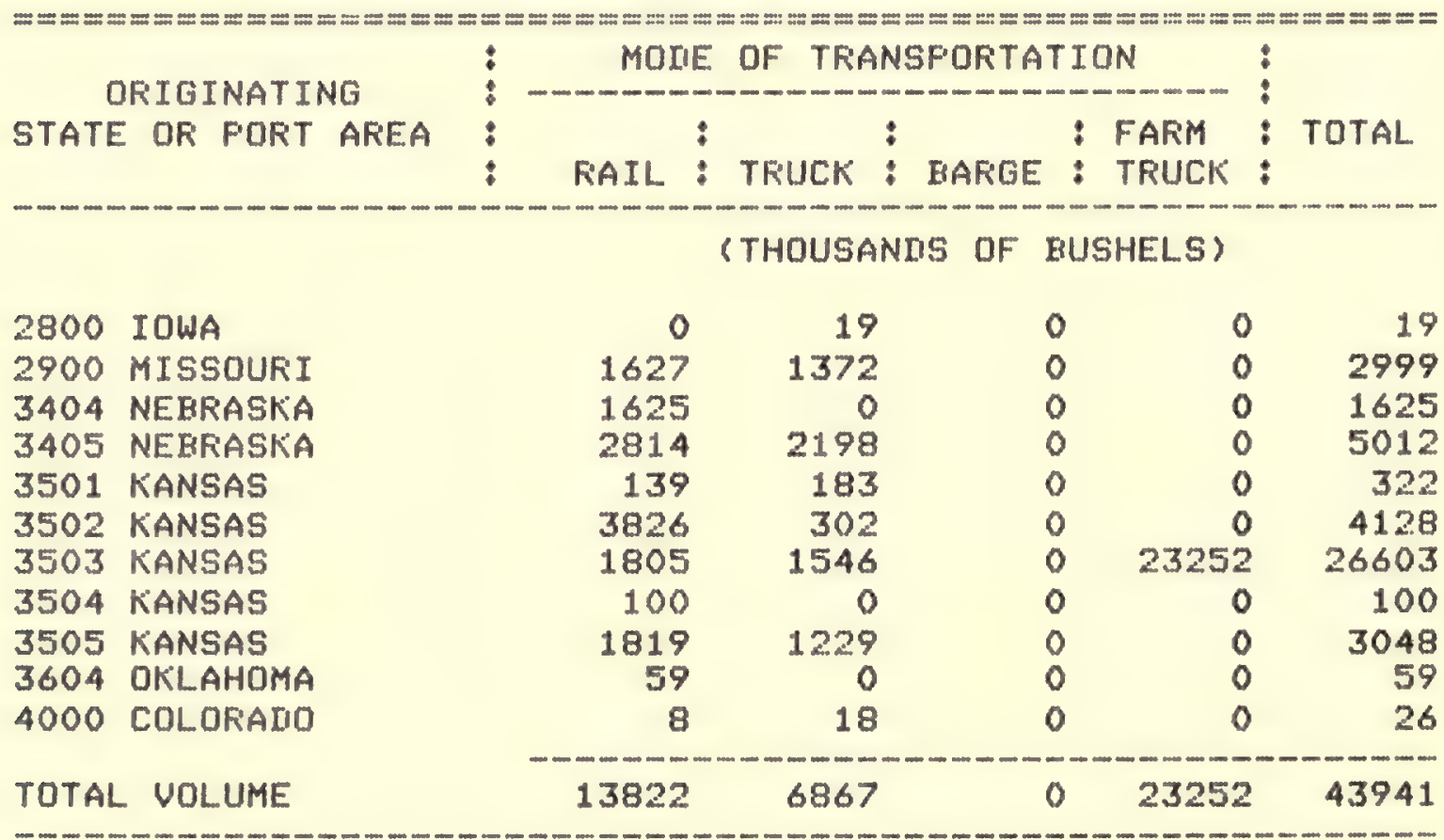


TABLE 46. 1977 SOFGHUM SHIFMENTS TO VAFIOUS IIESTINATIONS BY FIFIMS IN AFEA 3503, KANSAS

\begin{tabular}{|c|c|c|c|c|c|}
\hline DESTINATION & 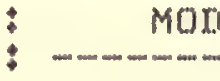 & E OF TRA & ANSFOFITAT & $\operatorname{TON}$ & \\
\hline STATE OR PORT AREA & FiATL. & : TFuCK & : EARGE & $\begin{array}{l}\mathrm{F} \\
\vdots \mathrm{T}\end{array}$ & TOTAI.. \\
\hline
\end{tabular}

(THOUSANIS OF BUSHELS)

2200 ILLINOIS

2900 MTSSOURT

3005 ARKANSAS

3016 ARKANSAS

3100 LOUISIANA

3500 K゙ANSAS

3502 KANSAS

3503 KIANSAS

3504 KANSAS

3505 KANSAS

3602 OKLAHOMA

3604 OKLAHOMA

3711 TEXAS

3745 TEXAS

4704 CALIFORNIA

7302 LOUTSIANA GULF

7303 NO. TEXAS GULFF

7304 SO. TEXAS GULF

TOTAL. VOL..UME
83

3822

688

3422

688

0

1644

1805

238

3105

1181

342

285

3382

512

0

11621

7468

40286

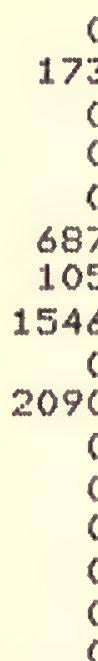

0
173

0

0

0

687

105

1546

2090

0

0

0

0

0

0

1330

21

5952

$\begin{array}{rrr}0 & 0 & 83 \\ 0 & 0 & 3995 \\ 0 & 0 & 688 \\ 0 & 0 & 3422 \\ 0 & 0 & 688 \\ 0 & 0 & 687 \\ 0 & 0 & 1749 \\ 0 & 0 & 3351 \\ 0 & 0 & 238 \\ 0 & 0 & 5195 \\ 0 & 0 & 1191 \\ 0 & 0 & 342 \\ 0 & 0 & 285 \\ 0 & 0 & 3382 \\ 0 & 0 & 512 \\ 552 & 0 & 552 \\ 0 & 0 & 12951 \\ 0 & 0 & 7489 \\ -552 & 0 & 46790\end{array}$

83

688

422

688

687

3351

238

5195

342

285

3.382

512

552

7489

46790

TABLE 47. 1977 SOFGHUM FECETFTS FROM UARIOUS ORIGINS BY FIFMS IN AFEA 3504, KANSAS

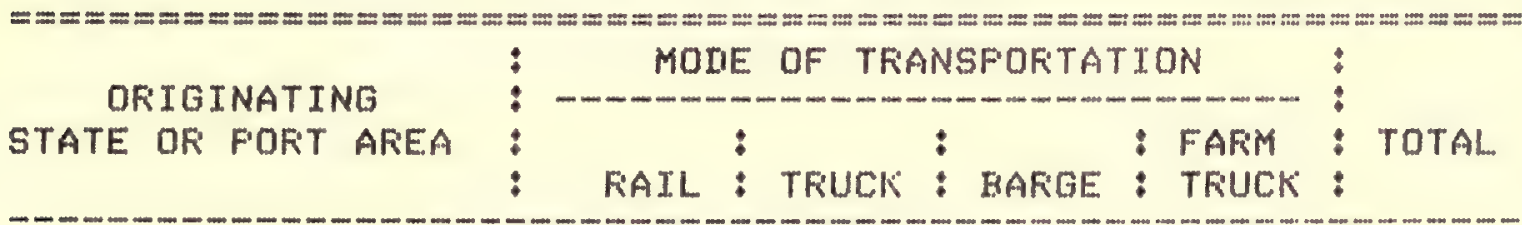

(THOUSANIS OF RUSHELS)

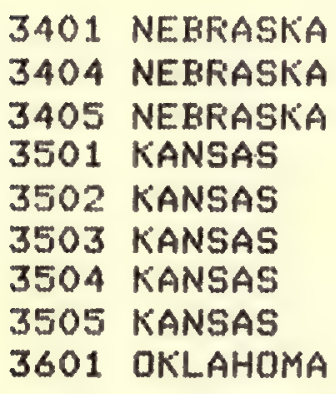

TOTAL VOLUME

$\begin{array}{rrrrr}108 & 0 & 0 & 0 & 108 \\ 60 & 0 & 0 & 0 & 60 \\ 330 & 4 & 0 & 0 & 334 \\ 1921 & 216 & 0 & 0 & 2137 \\ 2467 & 698 & 0 & 0 & 3165 \\ 238 & 0 & 0 & 0 & 238 \\ 2877 & 1438 & 0 & 18120 & 22435 \\ 664 & 754 & 0 & 0 & 1418 \\ 93 & 28 & 0 & 0 & 121 \\ -7758 & 3138 & 0 & 18120 & 30016\end{array}$


TAELE 48. 1977 SORGHUM SHIFMENTS TO VARIOUS RESTINATIONS EY FIFIS IN AREA 3504, KANSAS

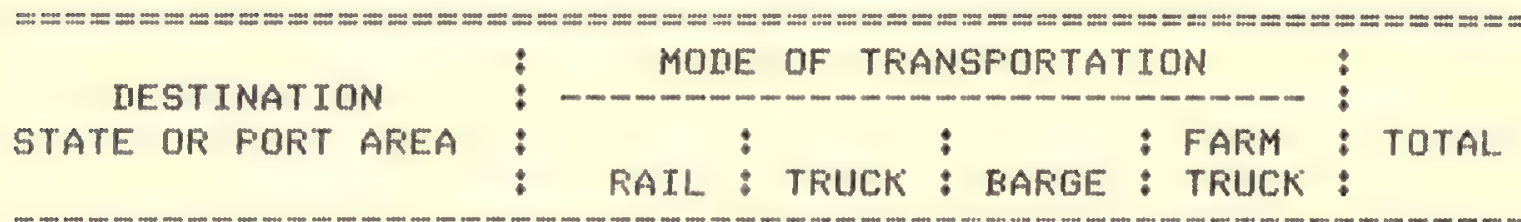

(THOUSANDS OF BUSHELS)

\begin{tabular}{|c|c|c|c|c|c|c|}
\hline 2900 & MISSDUFiI & 0 & 731 & 0 & 0 & 731 \\
\hline 3500 & KANSAS & 460 & 112 & 0 & 0 & 572 \\
\hline 3502 & KANSAS & 146 & 0 & 0 & 0 & 14 \\
\hline 3503 & KANSAS & 100 & 0 & 0 & 0 & 100 \\
\hline 3504 & KANSAS & 2877 & 1438 & 0 & 0 & 431 \\
\hline 3505 & KANSAS & 108 & 0 & 0 & 0 & 10 \\
\hline 3602 & OKLAHOMA & 1216 & 457 & 0 & 0 & 167 \\
\hline 3711 & TEXAS & 1274 & 1110 & 0 & 0 & 238 \\
\hline 3723 & TEXAS & 320 & 162 & 0 & 0 & 48 \\
\hline 3745 & TEXAS & 0 & 696 & 0 & 0 & \\
\hline 3789 & TEXAS & 151 & 138 & 0 & 0 & 28 \\
\hline 4401 & AFIIZONA & 3449 & 173 & 0 & 0 & 362 \\
\hline 4701 & CAL IFOFINIA & 206 & 0 & 0 & 0 & \\
\hline 4703 & CAL IFOFNIA & 23 & 0 & 0 & 0 & \\
\hline 4704 & CALIFORNIA & 1224 & 0 & 0 & 0 & 122 \\
\hline 7303 & NO. TEXAS GULF & 2220 & 0 & 0 & 0 & 222 \\
\hline 7304 & SO. TEXAS GUL.F & 1577 & 0 & 0 & 0 & 157 \\
\hline 7403 & CALIFORINIA & 24 & 0 & 0 & 0 & \\
\hline & VOLUME & 15375 & 5017 & 0 & 0 & 2039 \\
\hline
\end{tabular}

TARLE 49. 1977 SORGHUM FECEIFTS FFOM VARIOUS ORIGINS RY FIFMS IN AFEA 3505, K゙ANSAS

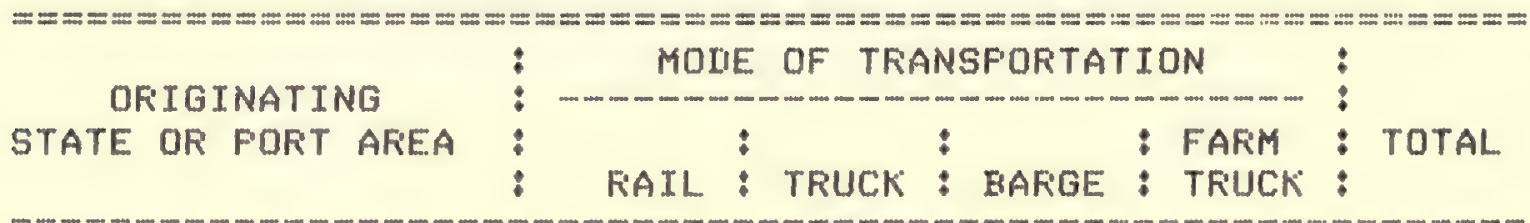

(THOUSANDS OF BUSHELS?

\begin{tabular}{|c|c|c|c|c|c|c|}
\hline 2900 & MISSDURI & 266 & 0 & 0 & 0 & 266 \\
\hline 3404 & NEBFASKA & 1108 & 0 & 0 & 0 & 1108 \\
\hline $\begin{array}{l}3405 \\
3501\end{array}$ & $\begin{array}{l}\text { NERFASKKA } \\
\text { KANSAS }\end{array}$ & $\begin{array}{r}3365 \\
365\end{array}$ & $\begin{array}{r}129 \\
0\end{array}$ & $\begin{array}{l}0 \\
0\end{array}$ & $\begin{array}{l}0 \\
0\end{array}$ & $\begin{array}{r}3494 \\
365\end{array}$ \\
\hline 3502 & KANSAS & 1642 & 52 & 0 & 0 & 1694 \\
\hline $\begin{array}{l}3503 \\
3504\end{array}$ & $\begin{array}{l}\text { KANSAS } \\
\text { KANSAS }\end{array}$ & $\begin{array}{r}3105 \\
108\end{array}$ & $\begin{array}{r}2090 \\
0\end{array}$ & $\begin{array}{l}0 \\
0\end{array}$ & $\begin{array}{l}0 \\
0\end{array}$ & $\begin{array}{r}5195 \\
108\end{array}$ \\
\hline 3505 & KANSAS & 1805 & 1607 & 0 & 32986 & 36398 \\
\hline
\end{tabular}


TARLE 50. 1977 SORGHUM SHIFMENTS TO UARIOUS DESTINATIONS BY FIFMS IN AREA 3505, KANSAS

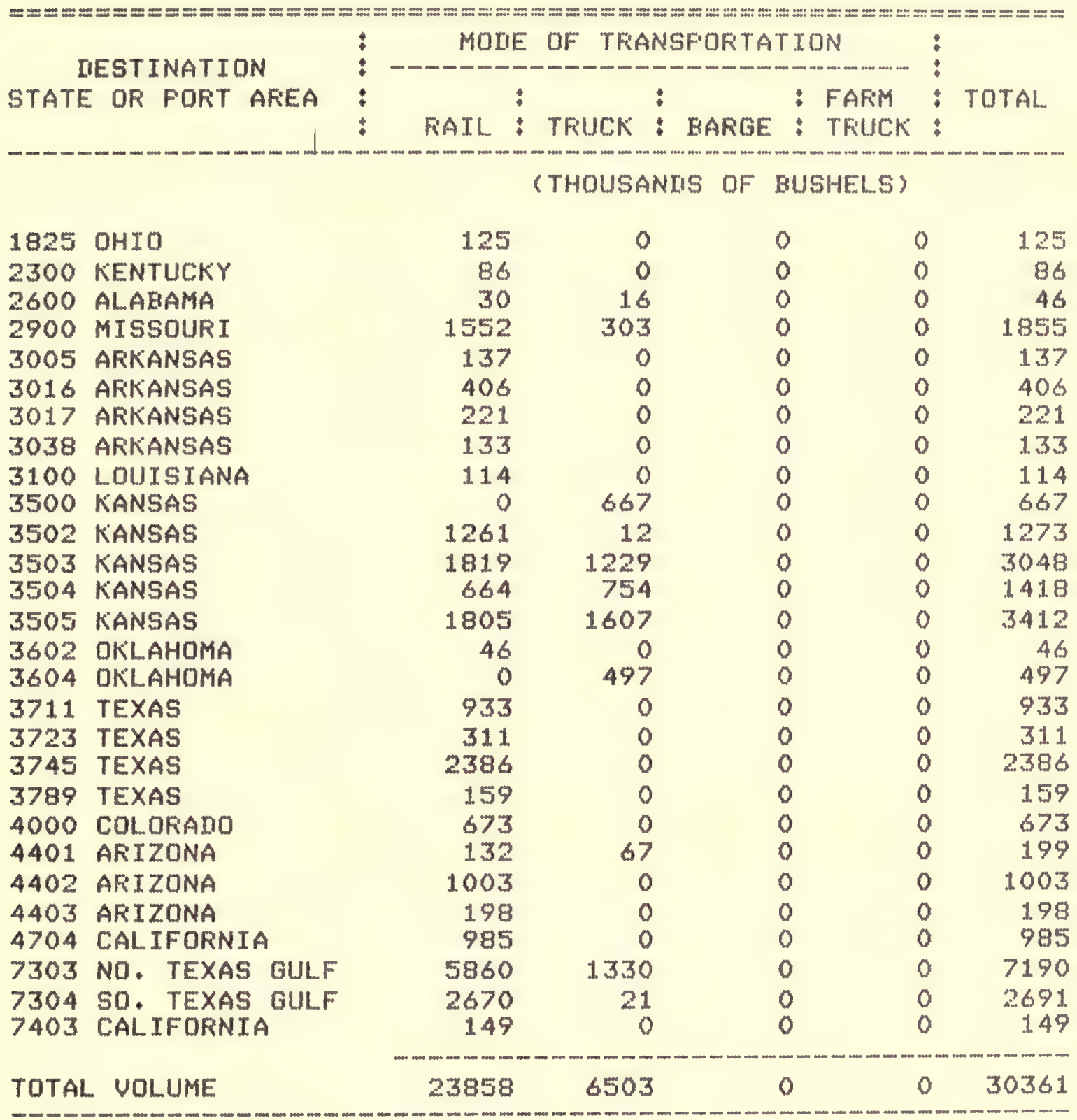


TABLE 51. 1977 SORGHUM RECEIFTS FROM UARIOUS ORIGINS BY FIRMS IN AREA 2300, KENTUCKY

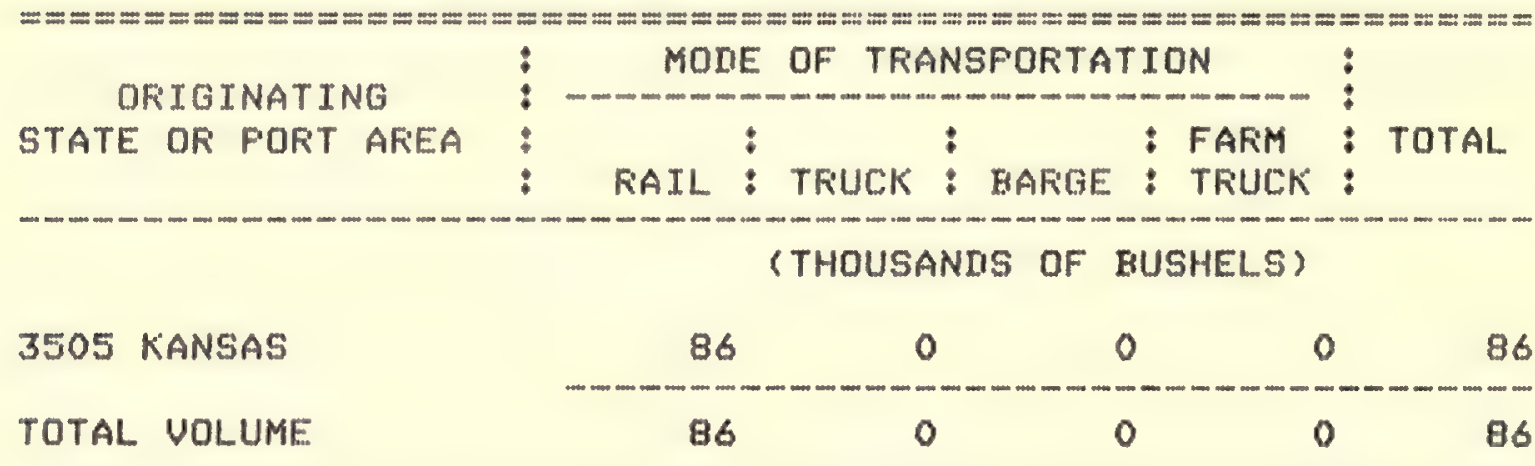

TAELE 52. 1977 SORGHUM SHIFMENTS TO VARIOUS DESTINATIONS BY FIRMS IN AREA 2300, KENTUCKY

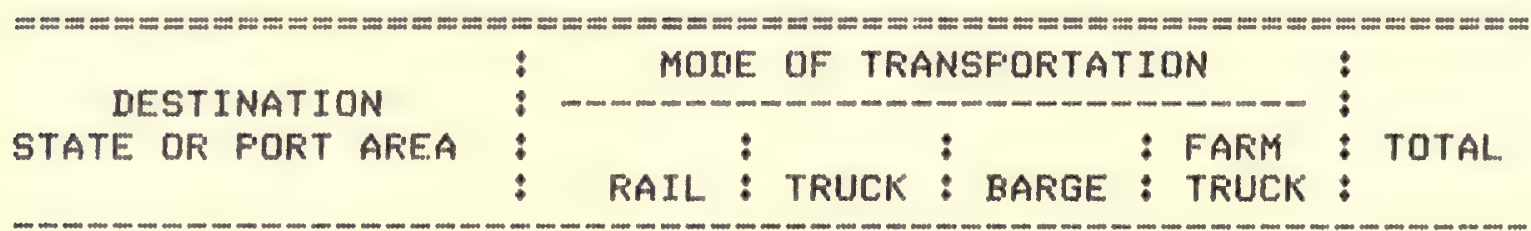

(THOUSANDS OF BUSHELS)

$\begin{array}{lccccc}2600 \text { ALABAMA } & 0 & 32 & 0 & 0 & 32 \\ \text { TOTAL VOLUME } & 0 & 32 & 0 & 0 & 32\end{array}$

TAELE 53. 1977 SORGHUM RECEIFTS FROM UARIOUS ORIGINS BY FIFIMS IN AREA 3100 , LOUISIANA

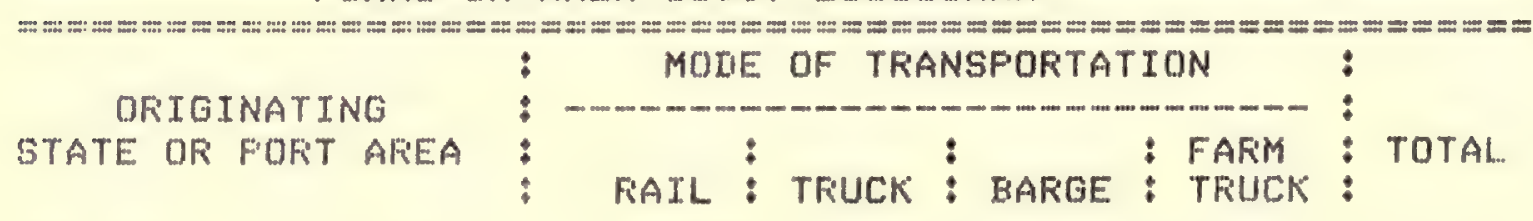

$\begin{array}{lrrrrr}2900 \text { MISSOURI } & 17 & 0 & 0 & 0 & 17 \\ 3038 \text { ARKANSAS } & 0 & 2 & 0 & 0 & 2 \\ 3100 \text { LOUISIANA } & 0 & 579 & 0 & 475 & 1054 \\ 3405 \text { NEBRASKA } & 673 & 0 & 0 & 0 & 673 \\ 3503 \text { KANSAS } & 688 & 0 & 0 & 0 & 688 \\ 3505 \text { KANSAS } & 114 & 0 & 0 & 0 & 114 \\ 3745 \text { TEXAS } & 289 & 50 & 0 & 0 & 339 \\ \text { 7302 LOUISIANA GULF } & 0 & 22 & 0 & 0 & 22 \\ \text { TOTAL UOLUME } & 1781 & 653 & 0 & 475 & 2909\end{array}$


TARLE 54. 1.977 SORGHUM SHIPMENTS TO VARIOUS IIESTINATIONS RY FIRMS IN AFEA 3100, LOUISIANA

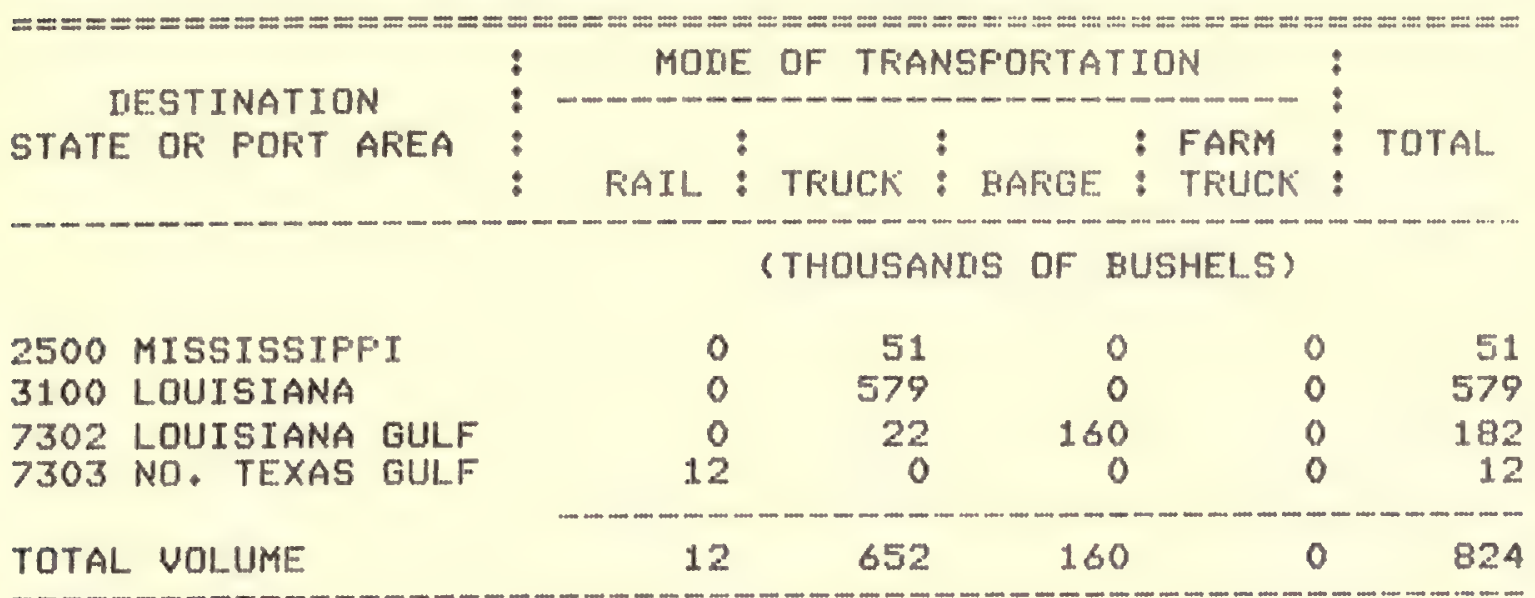

TABLE 55. 1977 SOFGHUM RECEIFTS FFOM UAFIOUS DRIGINS EY FIRMS IN AREA 2700, MINNESOTA

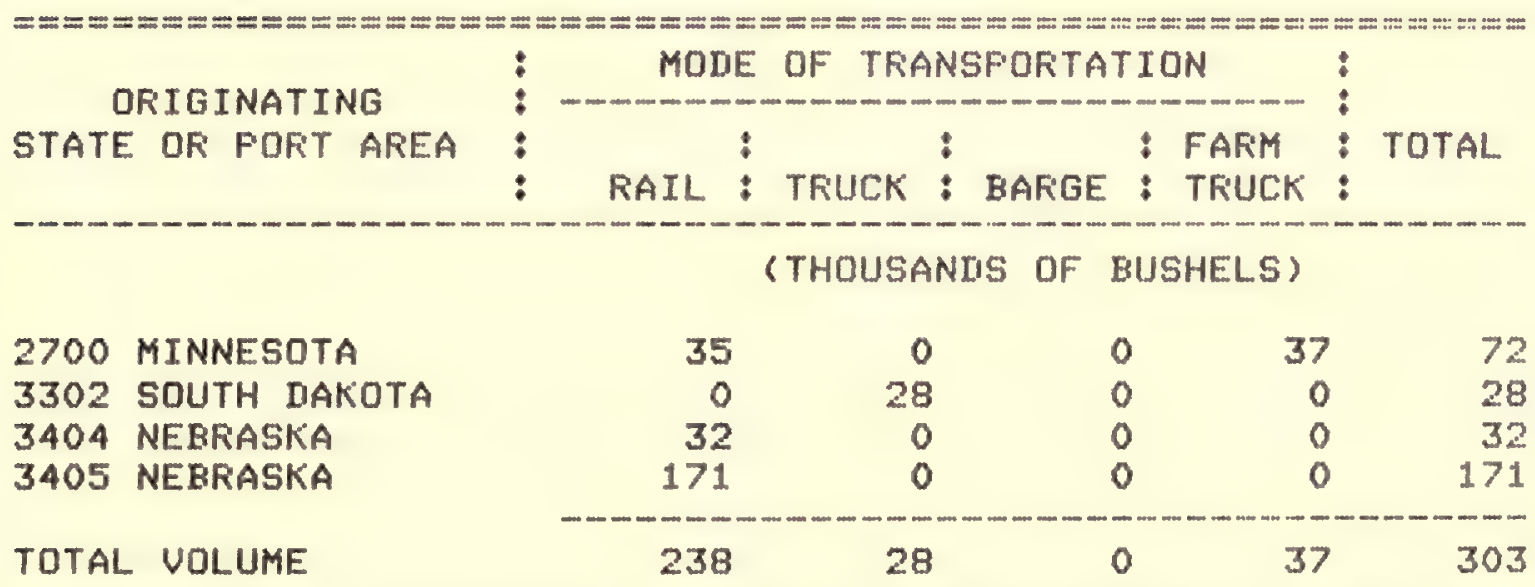

TAELE 56. 1977 SORGHUM SHIFMENTS TO VARIOUS IESTINATIONS BY FIRMS IN AREA 2700, MINNESOTA

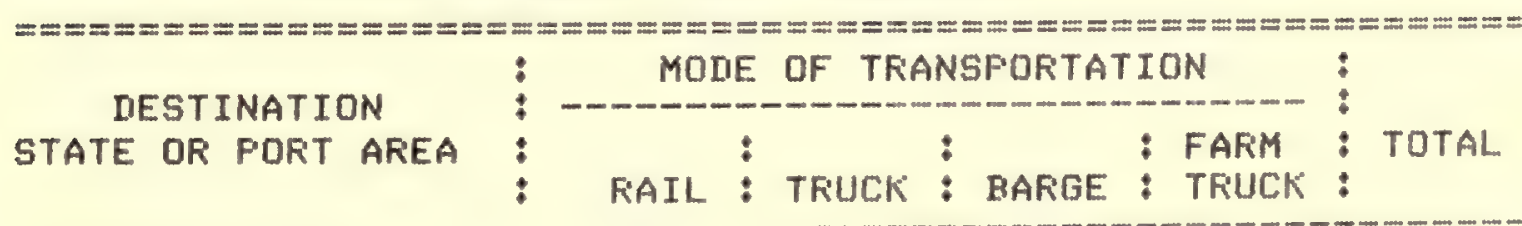

(THOUSANIS OF BUSHELS)

2700 MINNESOTA

TOTAL VOLUME

\begin{tabular}{ccccr}
35 & 0 & 0 & 0 & 35 \\
\hline 35 & 0 & 0 & 0 & 35
\end{tabular}


TAELE 57. 1977 SORGHUM FECEIFTS FFOM VARIOUS DFIGINS BY FIFMS IN AREA 2500, MTSSISSIFFI

\begin{tabular}{|c|c|c|c|c|c|c|c|c|}
\hline ORIGINATING & \multirow{3}{*}{$\vdots$} & MOLE & E DF TRA & \multicolumn{3}{|c|}{ TRANSFORTATION } & & \multirow{3}{*}{ TOTAL } \\
\hline STATE OR FORT AREA & & & : & : & $:$ & FAFM & & \\
\hline & & RAIL & : TRUCK & : BAFGE & $:$ & TRUCK & : & \\
\hline & & \multicolumn{3}{|c|}{ (THOUSANIIS OF } & \multicolumn{3}{|c|}{ BUSHELS) } & \\
\hline 2200 ILLINOIS & & 294 & C & 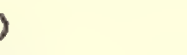 & 0 & & 0 & 294 \\
\hline 2500 MISSISSIPFI & & 0 & 8: & & 0 & & 0 & 82 \\
\hline 2800 IOWA & & 0 & 220 & & 0 & & 0 & 220 \\
\hline 2900 MISSDUFII & & 9 & & & 0 & & 0 & \\
\hline 3038 AFKKANSAS & & 0 & $9 \%$ & & 0 & & 0 & 97 \\
\hline 3100 LOUISIANA & & 0 & 5 & & 0 & & 0 & 51 \\
\hline TOTAL. VOLUME & & 303 & 45 & & 0 & & 0 & 753 \\
\hline
\end{tabular}

TABLE 58. 1977 SORGHUM SHIPMENTS TO VARIOUS IIESTINATIONS BY FIFIM IN AFEA 2500, MISSISSIFPI

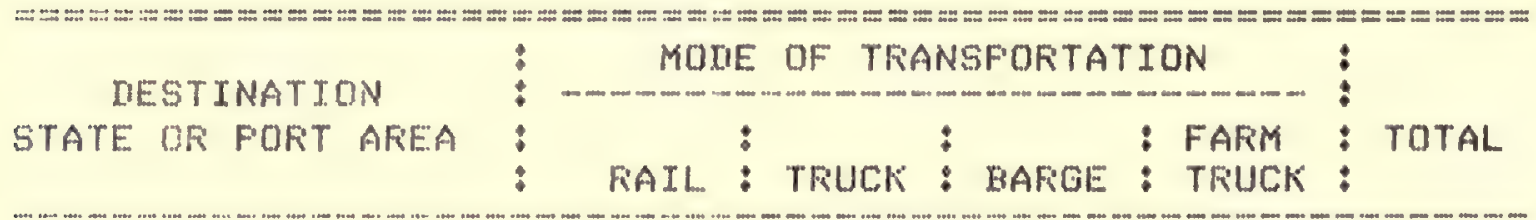

(THOUSANDIS OF BUSHELS?

$\begin{array}{lccccc}2500 \text { MISSISSIFPI } & 0 & 82 & 0 & 0 & 82 \\ \text { TOTAL VOLUME } & 0 & 82 & 0 & 0 & 82\end{array}$


TAELE 59, 1977 SORGHUM FECEIFTS FFOM VAFITUS OFIGINS BY FIRMS IN AFEA 2900, MISSOURT.

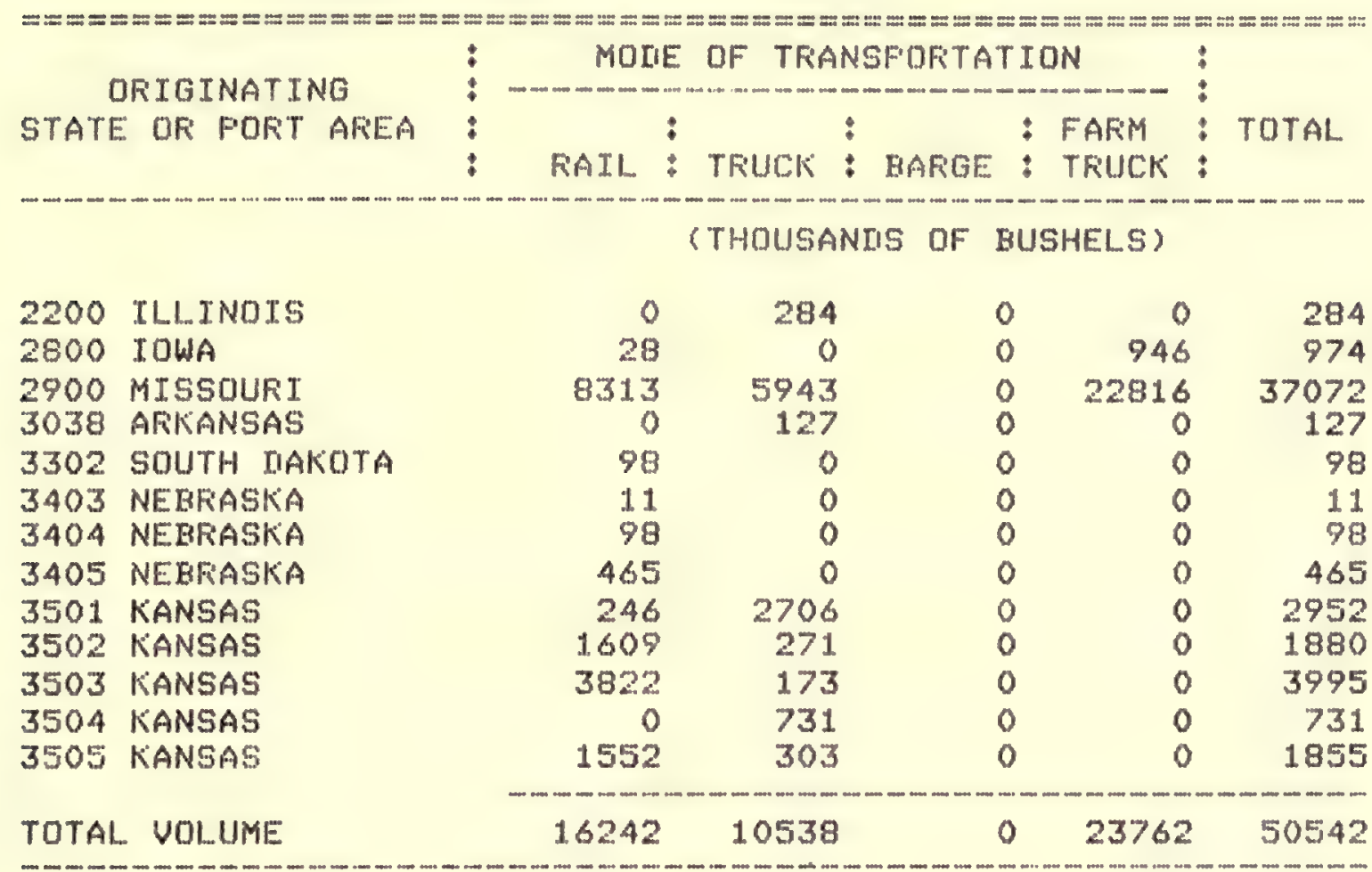


TAELE 60. 1977 SOFGHUM SHIFMENTS TO VAFIOUS DESTINATIONS BY FIFMS IN AFEA 2900, MISSOURI

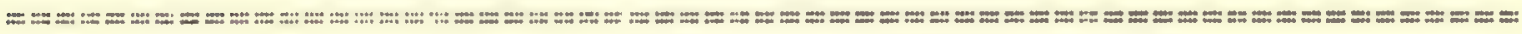

IEESTNATION

STATE OF FOFT AFEA

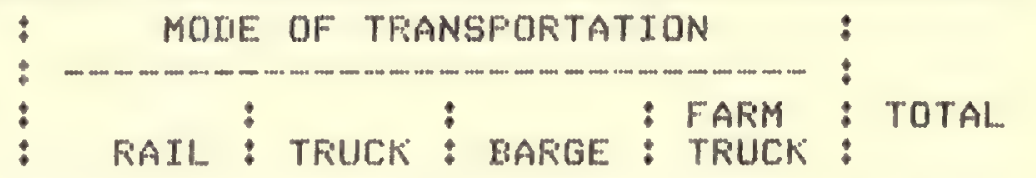

\begin{tabular}{|c|c|c|c|c|c|c|}
\hline \multirow[b]{2}{*}{2500} & \multirow[b]{2}{*}{ MISSTSSIFFI } & \multicolumn{3}{|c|}{ (THOUSANIS OF } & BUSHELS ) & \\
\hline & & 9 & 0 & 0 & 0 & 9 \\
\hline 2900 & MISSOUFi & 8313 & 5943 & 0 & 0 & 14256 \\
\hline 3005 & AFIKANSAS & 912 & 27 & 0 & 0 & 839 \\
\hline 3016 & AFKKANSAS & 123 & 950 & 0 & 0 & 1073 \\
\hline 3017 & AFKKANSAS & 700 & 0 & 0 & 0 & 700 \\
\hline 3038 & AFKKANSAS & 0 & 291 & 0 & 0 & 291 \\
\hline 3100 & LOUTSTANA & 1.7 & 0 & 0 & 0 & 17 \\
\hline 3405 & NEBFASKA & 0 & 4 & 0 & 0 & 4 \\
\hline 3502 & K゙ANSAS & 73 & 0 & 0 & 0 & 73 \\
\hline 3503 & KANSAS & 1627 & 1372 & 0 & 0 & 2999 \\
\hline 3505 & KIANSAS & 266 & 0 & 0 & 0 & 266 \\
\hline 3604 & OK゙L...AHOMA & 17 & 0 & 0 & 0 & 17 \\
\hline 3711 & TEXAS & 14 & 0 & 0 & 0 & 14 \\
\hline $\begin{array}{l}3712 \\
3723\end{array}$ & $\begin{array}{l}\text { TEXAS } \\
\text { TEXAS }\end{array}$ & $\begin{array}{r}0 \\
1873\end{array}$ & $\begin{array}{r}36 \\
387\end{array}$ & $\begin{array}{l}0 \\
0\end{array}$ & $\begin{array}{l}0 \\
0\end{array}$ & $\begin{array}{r}36 \\
2260\end{array}$ \\
\hline 3745 & TEXAS & 2206 & 0 & 0 & 0 & 2206 \\
\hline 4401 & AFIZOONA & 82 & 0 & 0 & 0 & 82 \\
\hline 4704 & CAL. IFOFNIA & 2075 & 0 & 0 & 0 & 2075 \\
\hline 7302 & LOUISIANA GULF & 0 & 0 & 2966 & 0 & 2966 \\
\hline 7303 & NO. TEXAS GULLF & 6178 & 0 & 1024 & 0 & 7202 \\
\hline 7304 & SO. TEXAS GULF & 4336 & 13 & 0 & 0 & 4349 \\
\hline 7402 & FUGET SOUNM & 172 & 0 & 0 & 0 & 172 \\
\hline TOTAL & VOLUME & 28993 & 9023 & 3990 & 0 & 41906 \\
\hline
\end{tabular}

TAELE 61. 1.977 SOFGHUM FEECEIFTS FFOM VARIOUS ORIGINS BY FTFMS IN AREA 3401, NEBFISKA

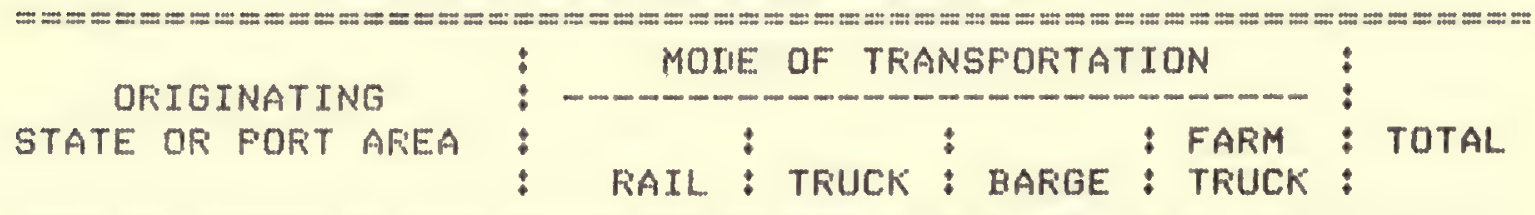

(THOUSANDS OF EUSHELS)

\begin{tabular}{lccccrr}
3401 NEEFASKA & 0 & 13 & 0 & 325 & 338 \\
3403 NERRASKA & 0 & 20 & 0 & 0 & 20 \\
3404 NEBRASKA & 0 & 26 & 0 & 0 & 26 \\
& & 0 & 59 & 0 & 325 & 384 \\
\hline
\end{tabular}


TAELE 62. 1977 SORGHUM SHIFMENTS TO VAFTOUS IESTINATIONS BY FIFIS IN AFEA 3401, NEBFISKKA

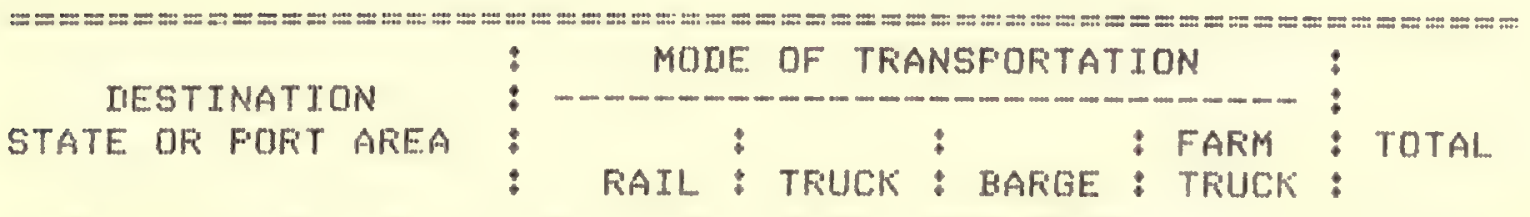

(THOUSANIIS OF FUSHEL.S〉

$\begin{array}{lrrrrrr}3401 \text { NEBFASKA } & 0 & 13 & 0 & 86 & 99 \\ 3404 \text { NEBFIASKA } & 44 & 11 & 0 & 0 & 55 \\ 3405 \text { NEBFASKA } & 28 & 0 & 0 & 0 & 28 \\ 3502 \text { KANSAS } & 123 & 0 & 0 & 0 & 123 \\ 3504 \text { KANSAS } & 108 & 0 & 0 & 0 & 108 \\ 4000 \text { COLOFALIO } & 60 & 97 & 0 & 64 & 221 \\ \text { TOTAL VOLUME } & 363 & 121 & 0 & 150 & 634\end{array}$

TAELE 63. 1977 SOFGHUM RECEIFTS FFOM UAFIQUS ORIGTNS BY FIFIMS IN AFIEA 3402, NEBFIASKAA

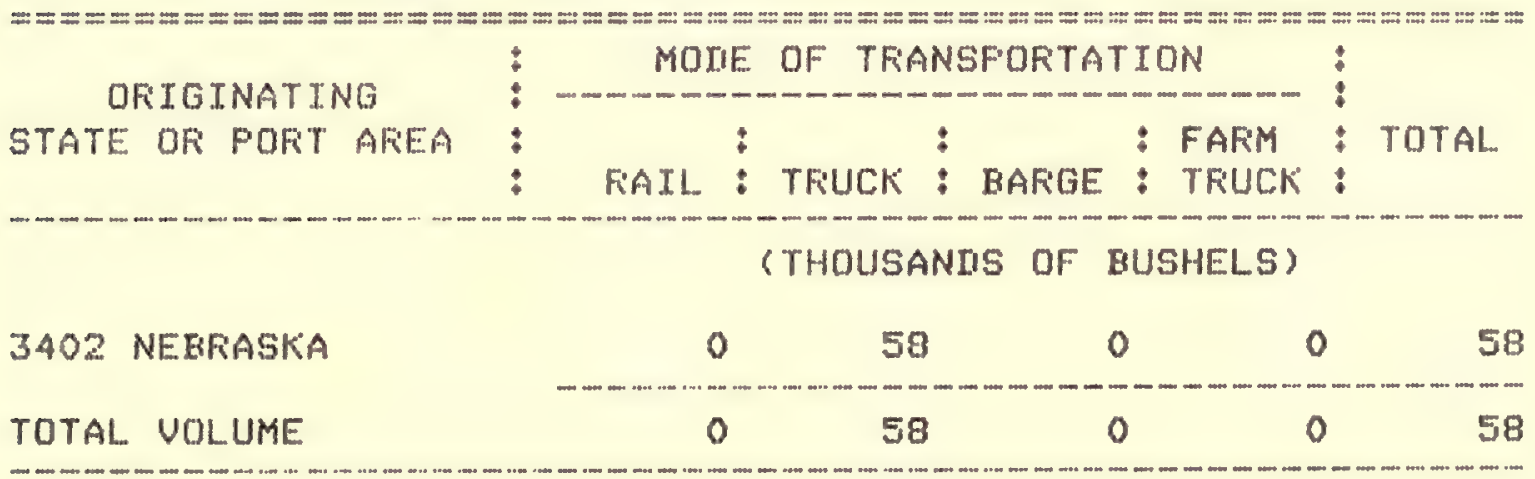

TAELE 64. 1977 SOFGHUM SHIFMENTS TO VARIOUS DESTINATIONS BY FIRMS IN AREA 3402 , NEBFIASKA

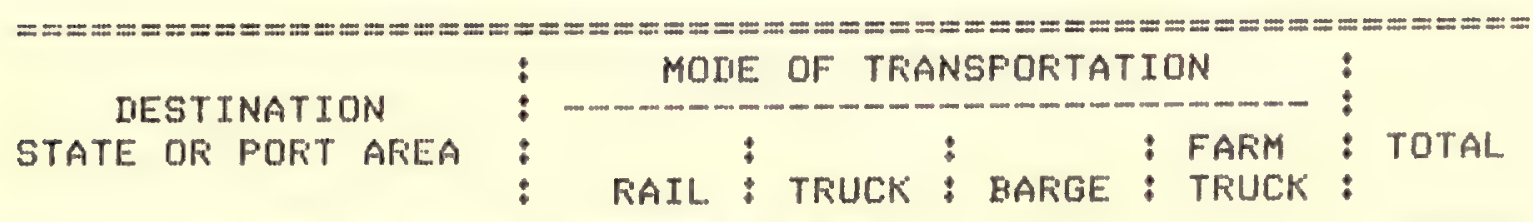

(THOUSANIS OF BUSHELS)

3402 NEBFIASKRA

3502 KANSAS

TOTAL VOLUME

\begin{tabular}{ccccr}
0 & 58 & 0 & 0 & 58 \\
194 & 0 & 0 & 0 & 194 \\
\hline 194 & 58 & 0 & 0 & 252
\end{tabular}


TABLE 65. 1977 SOFGHUM FECEIFTS FFOM UARIDUS OFIGINS EY FIFMS IN AREA 3403, NEHFASKA

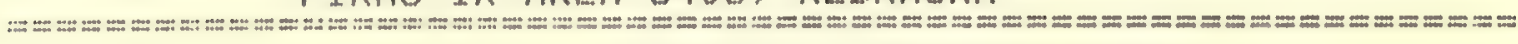

OFIGINATING
STATE OF FOFT AFEA

(THOUSANIIS OF BUSHELS)

$\begin{array}{llcccrr}3302 & \text { SOUTH IIAKOTA } & 0 & 0 & 0 & 42 & 42 \\ 3403 \text { NERRASKKA } & 0 & 950 & 0 & 2876 & 3826 \\ 3405 \text { NERFASKKA } & 29 & 176 & 0 & 43 & 248 \\ \text { TOTAL UDLUME } & 29 & 1126 & 0 & 2961 & 4116\end{array}$

TARIE... 66. 1977 SCRGHUM SHIFMENTS TO VARIOUS DESTINATIONS BY FTFMS IN AFEA 3403 , NEBFIASKA

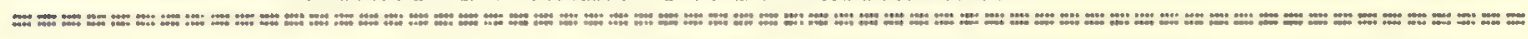

DESTINATION

STATE OF FOFT AFEEA

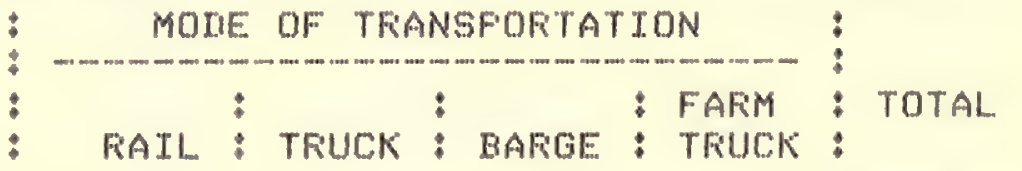

(THOUSANIIS OF RUSHELS)

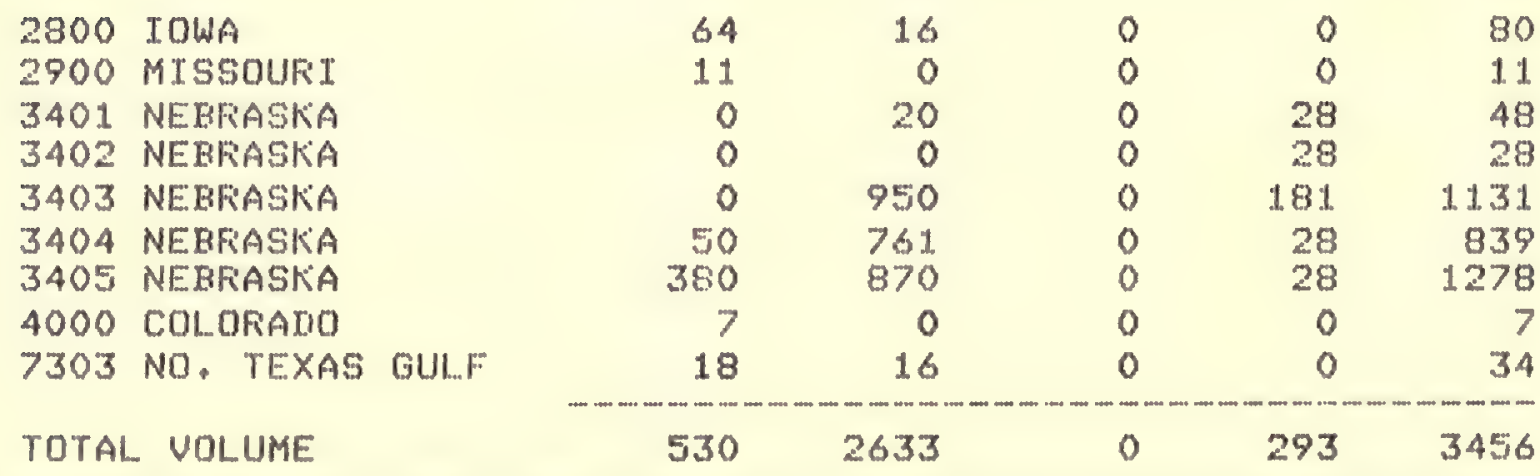

TARLE: 67. 1977 SORGHUM FECEIFTS FROM VARIOUS OFIGINS BY FIRMS IN AFEA 3404, NEERASKA

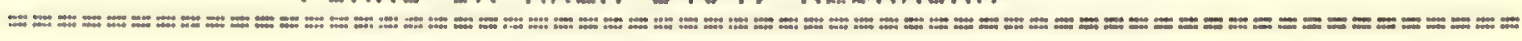

OFIGINATING

STATE OF FORT AREA
MONE OF TRANSFOFTATION

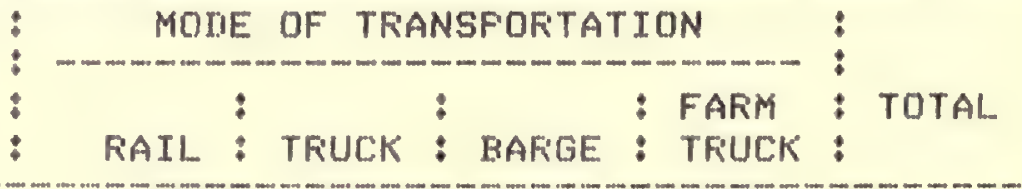

(THOUSANIIS OF BUSHELS)

3401 NEBFASKA

3403 NEBRASK

3404 NEBRASKIA

3405 NEEFIASKA

3502 KANSAS

TOTAL VOLUME

$\begin{array}{rrrrr}44 & 11 & 0 & 0 & 55 \\ 50 & 761 & 0 & 0 & 811 \\ 5424 & 5180 & 0 & 21281 & 31885 \\ 1925 & 1108 & 0 & 102 & 3135 \\ 0 & 0 & 0 & 171 & 171 \\ 7443 & 7060 & 0 & 21554 & 36057\end{array}$

55

811

1885

171

$7443 \quad 7060$

36057 
TAELE 68, 1977 SOFGHUM SHIPMENTS TO UARIOUS IIESTINATIONS BY FIRMS IN AREA 3404, NEBFASKIA

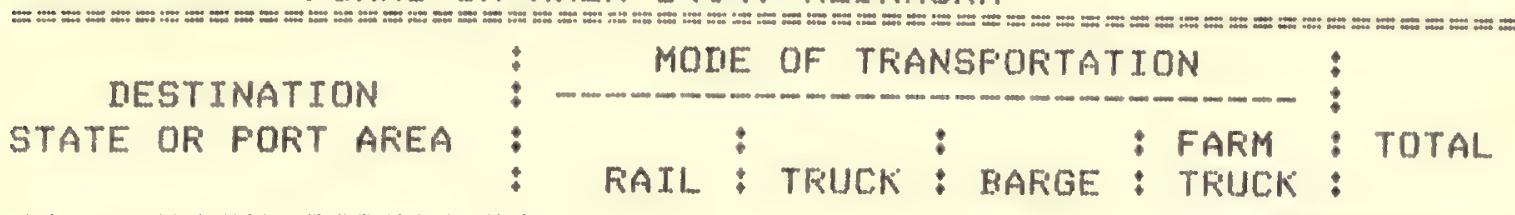

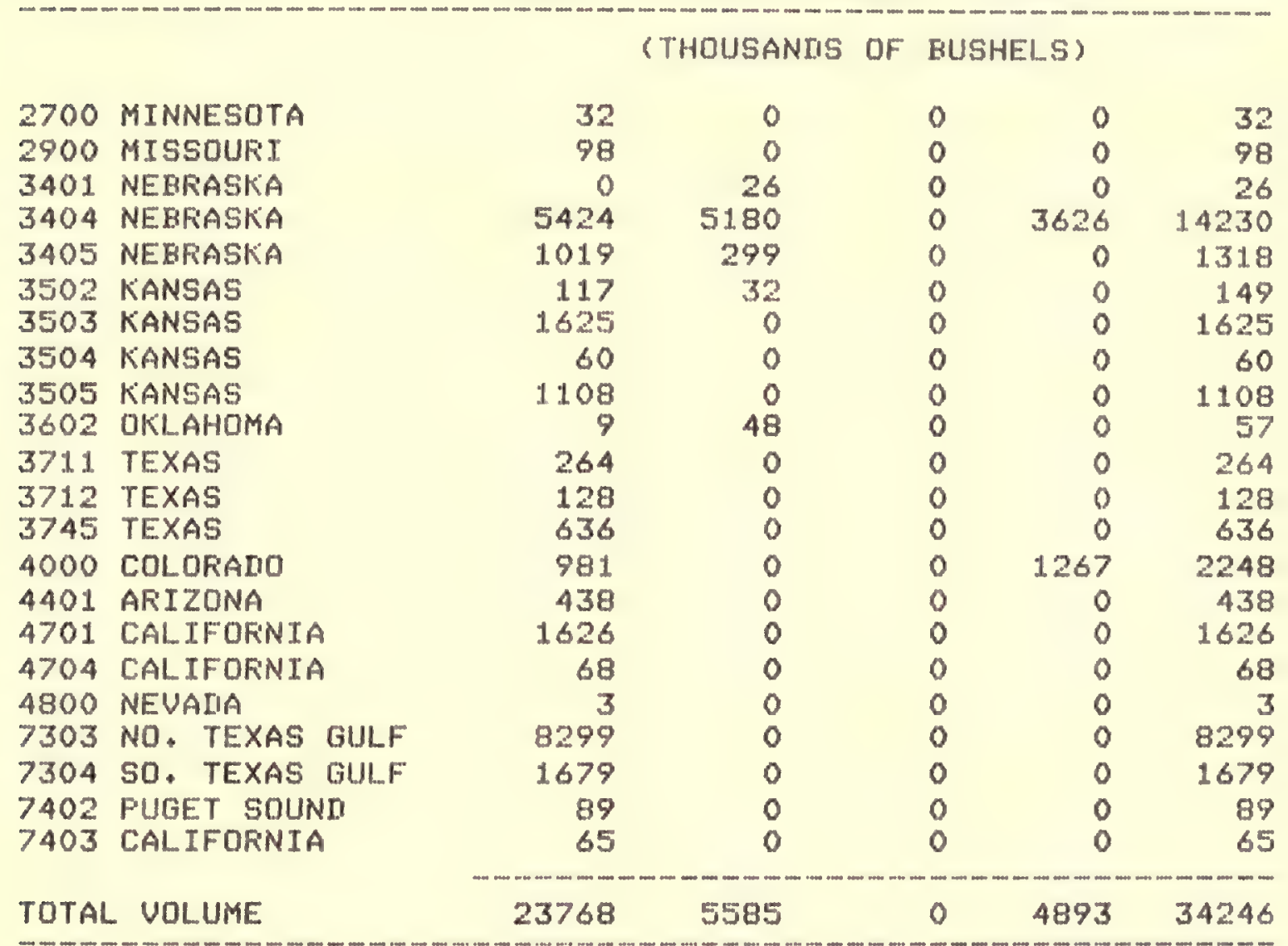

TABLE 69. 1977 SOFGHUM FECEIFTS FFOM UARIOUS ORIGINS BY FIFMS IN AFEA 3405, NEEFASKA

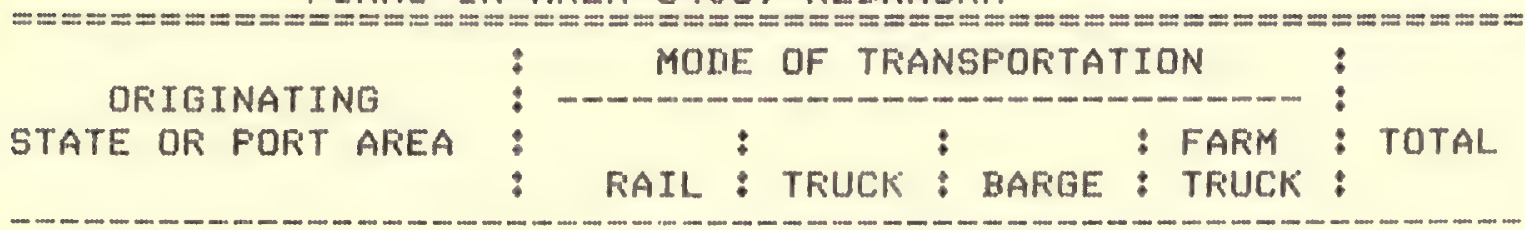

(THOUSANUS OF EUSHELS)

$\begin{array}{llrrrrr}2800 & \text { IOWA } & 14 & 19 & 0 & 9 & 42 \\ 2900 \text { MISSOURI } & 0 & 4 & 0 & 66 & 70 \\ 3401 \text { NEBRASKA } & 28 & 0 & 0 & 0 & 28 \\ 3403 \text { NEBRASKA } & 380 & 870 & 0 & 0 & 1250 \\ 3404 \text { NEBRASKA } & 1019 & 299 & 0 & 521 & 1839 \\ 3405 \text { NEBRASKA } & 43295 & 21797 & 0 & 95937 & 161029 \\ \text { TOTAL VOLUME } & -1793 & 0 & 96533 & 164258\end{array}$


TAELE 70. 1977 SOFGHUM SHIFMENTS TO UARIOUS IIESTINATIONS BY FIFMS IN AREA 3405, NEBRASKA

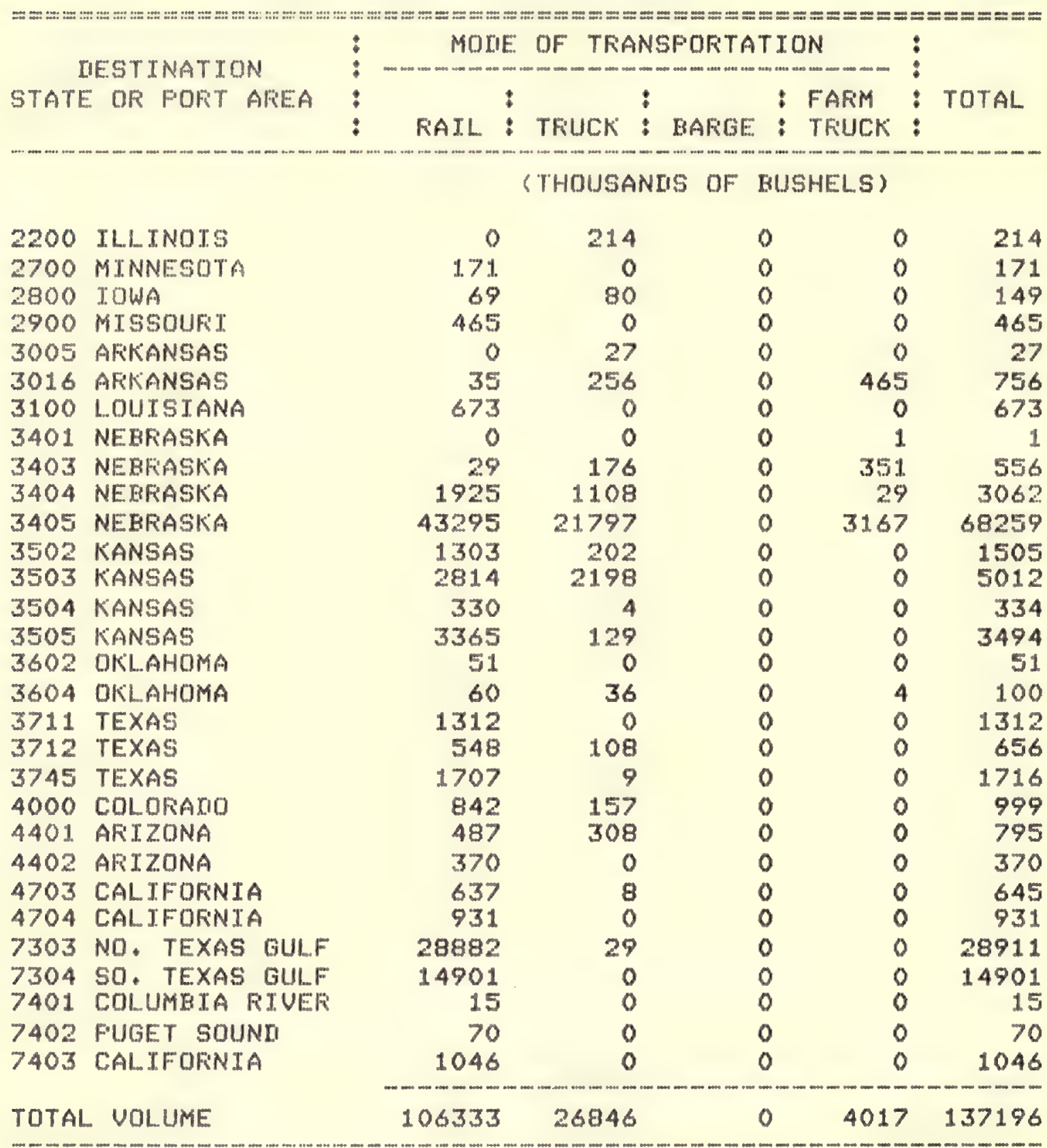


TABLE 71. 1977 SORGHUM FECEIFTS FFOM UARIOUS OFIGINS BY FIRMS IN AREA 4800 , NEUAIIA

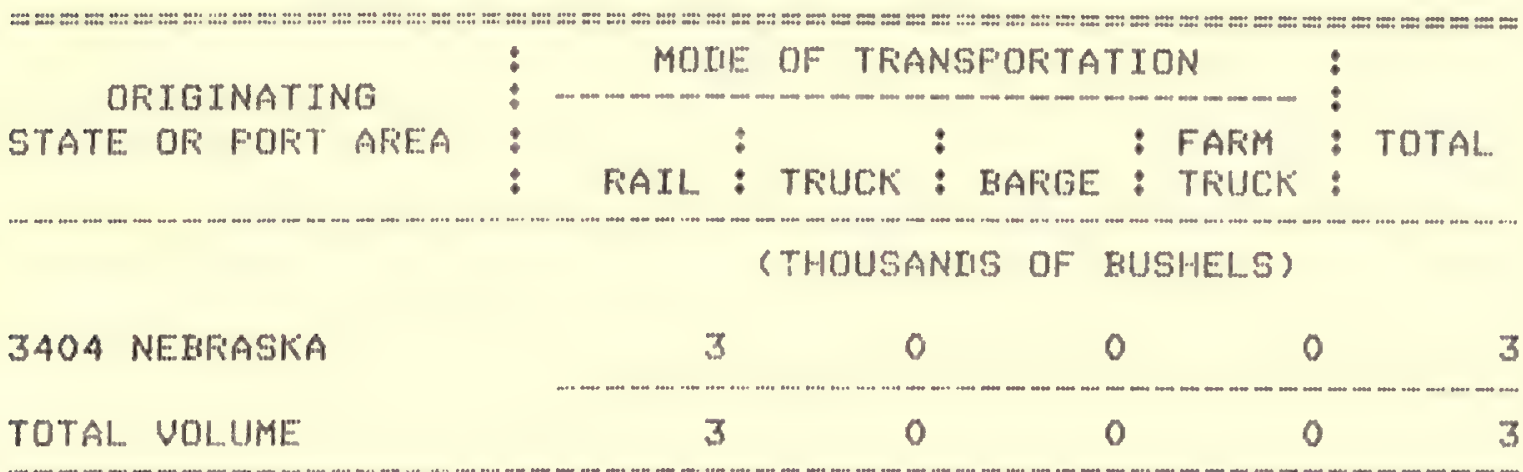

TARIE 72. 1977 SORGHUM RECEIFTS FFOM UAFIOUS OFIGINS BY FIFMS IN AREA 4100 , NEW MEXICO

\begin{tabular}{|c|c|c|c|c|c|c|c|}
\hline OFIIGINATING & $\begin{array}{r}\text { Mor } \\
\ldots-\ldots-m\end{array}$ & E OF TFi & ANSFOFTA & IION & $\begin{array}{l}v \\
--\ldots-n\end{array}$ & $\vdots$ & \\
\hline STAYE OR FORT AREA & FAIL & : TFUCK & : RAFGE & $\begin{array}{l}F \\
\vdots T\end{array}$ & $\begin{array}{l}=A F I M \\
\text { TFUCK }\end{array}$ & $\vdots$ & TOTAL \\
\hline
\end{tabular}

(THOUSANDS OF BUSHELS)

$\begin{array}{lccccc}3712 \text { TEXAS } & 0 & 12 & 0 & 0 & 12 \\ 4100 \text { NEW MEXICO } & 0 & 0 & 0 & 9643 & 9643 \\ \text { TOTAL VOLUME } & 0 & 12 & 0 & 9643 & 9655\end{array}$

TAELE 73. 1977 SORGHUM SHTFMENTS TO VAFTOUS IIESTINATIONS EY FIFMS IN AFEA 4100. NEW MEXICO

\begin{tabular}{|c|c|c|c|c|c|c|c|}
\hline IIEST JNATION & $\vdots$ & MOIIE & DF TFA & INSFOFITAT & $\operatorname{ION}$ & $\vdots$ & \\
\hline STATE OF FOFIT AFEA & : & FAIL : & TFUUCK" & : EAFIGE & $\begin{array}{l}\text { : FARM } \\
\text { : TFUCK }\end{array}$ & : & TOTAL. \\
\hline
\end{tabular}

3711 TEXAS

3712 TEXAS

3767 TEXAS

4401 ARIZONA

4403 AFIIZONA

7304 SO. TEXAS GUL.F

TOTAL VOLUME

\section{(THOUSANIIS OF EUSHELS)}

\begin{tabular}{rrrrr}
72 & 1844 & 0 & 0 & 1916 \\
0 & 1590 & 0 & 0 & 1590 \\
0 & 100 & 0 & 0 & 100 \\
0 & 180 & 0 & 0 & 180 \\
290 & 10 & 0 & 0 & 300 \\
122 & 0 & 0 & 0 & 122 \\
\hline 484 & 3724 & 0 & 0 & 4208
\end{tabular}


TAELE 74, 1977 SORGHUM RECEIFTS FFOM VARIOUS ORIGINS BY FIFMS TN AREEA 1400, NOFTH CAROLINA

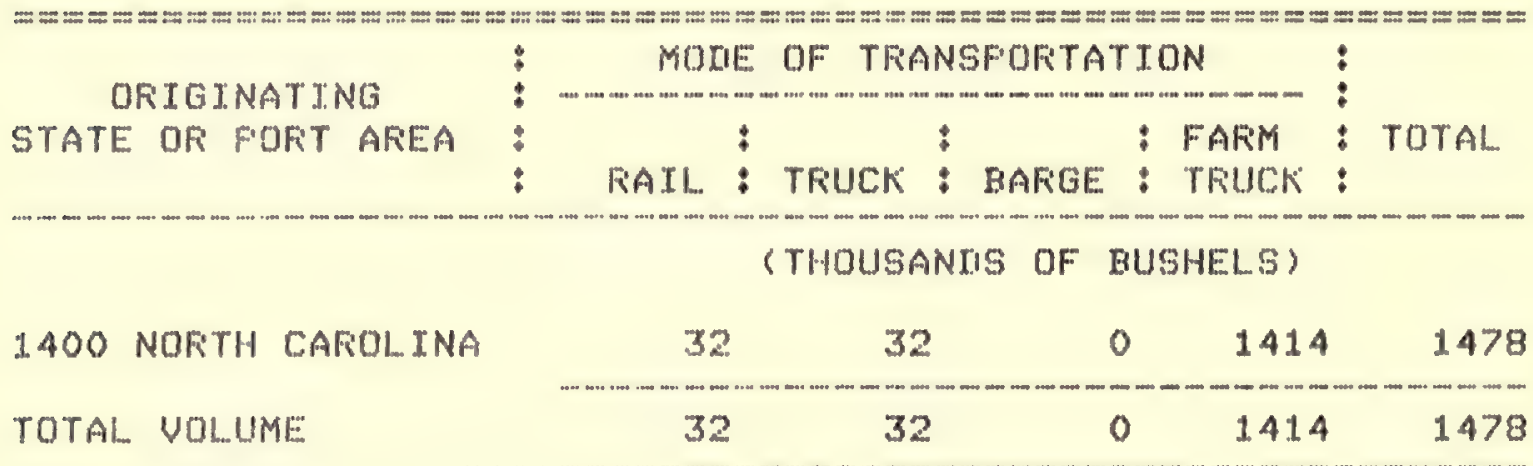

TAELE 75. 1977 SOFGHUM SHIFMENTS TO UAFIOUS DESTINATTONS BY FIFISS IN AREA 1.400\% NORTH CAFOLINA

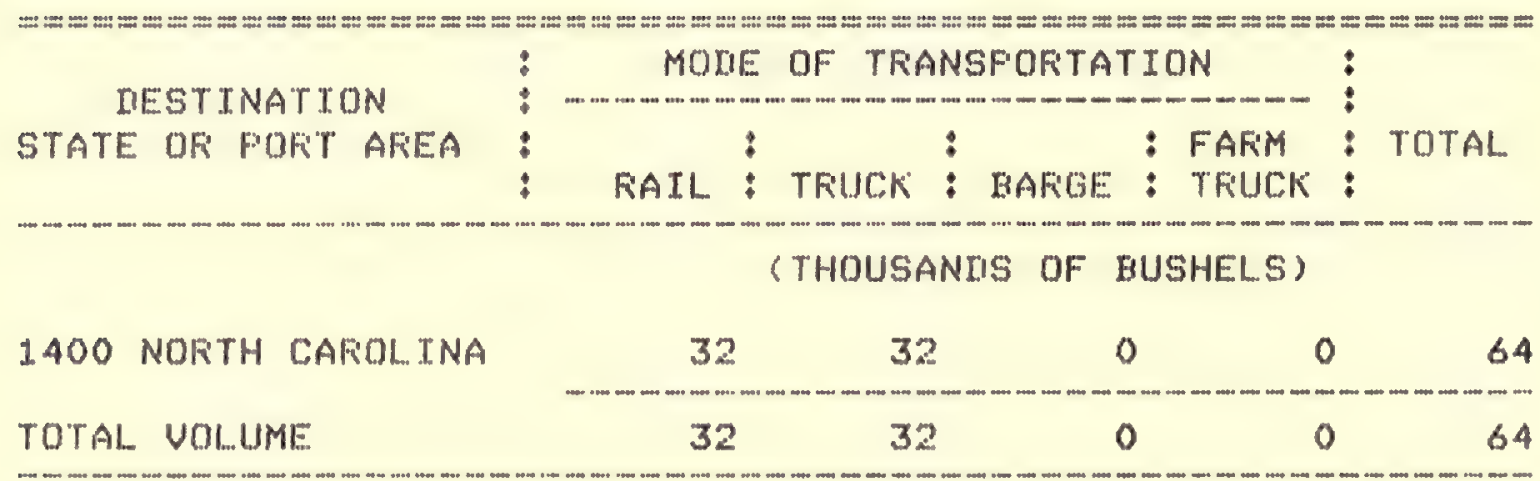

TARLE 76. 1977 SORGHUM FEEEIFTS FROM UARIOUS ORIGINS BY FIFIMS IN AFIEA 1825 , DHID

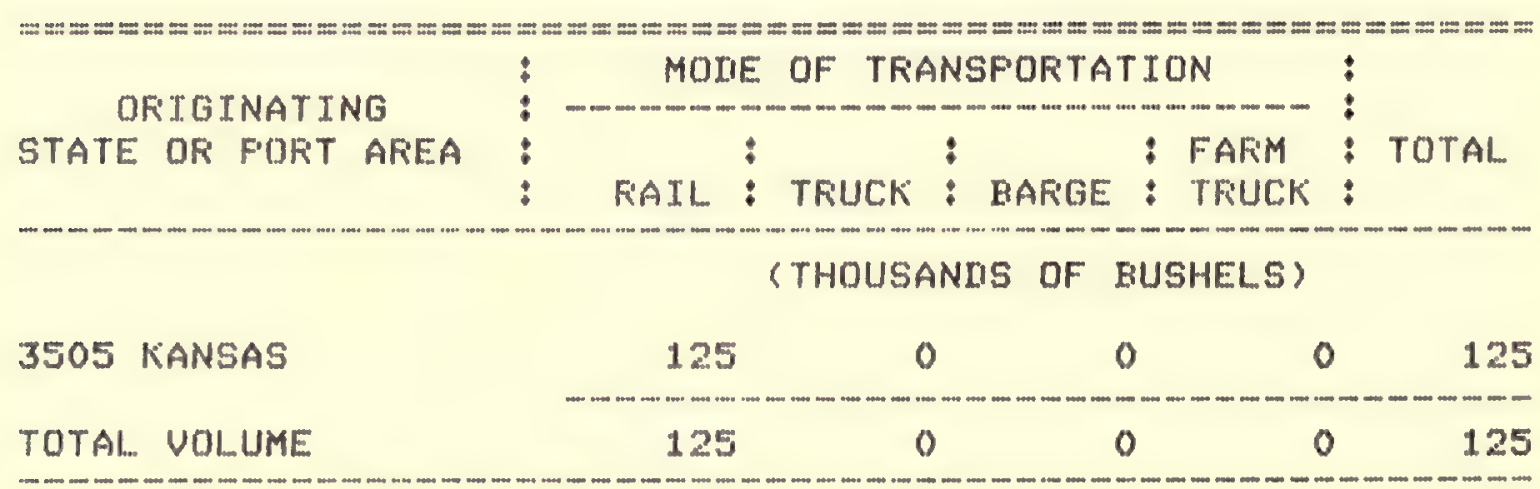


TAELE 77. 1977 SORGHUM RECEIFTS FROM VARIOUS ORIGINS BY FIRMS IN AKEA 3601, OKLAHOMA

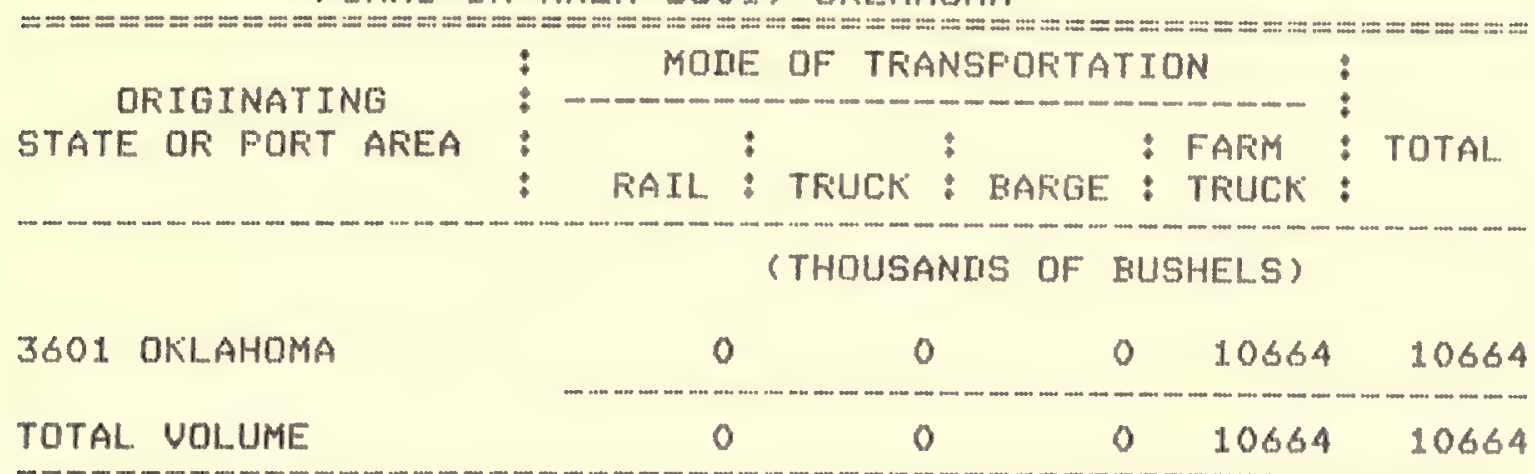

TABLE 78. 1977 SORGHUM SHIFMENTS TO VARIOUS RIESTINATIONS BY FIRMS IN AFEA 3601, OKLAHOMA

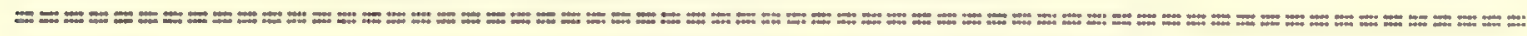

STATE OR POFT AREA
DIESTINATTON

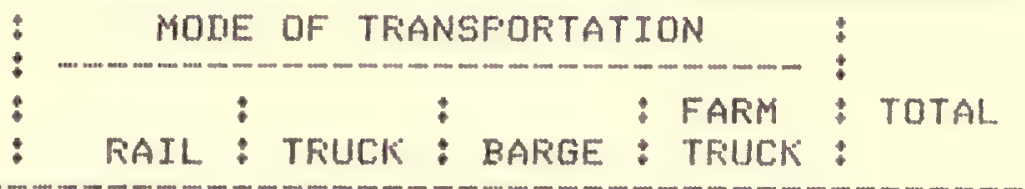

(THOUSANIS OF BUSHELS)

3504 KANSAS

3711 TEXAS

3712 TEXAS

3745 TEXAS

7303 NO. TEXAS GULF

7304 SO. TEXAS GLILF

TOTAL VOLUME

\begin{tabular}{rrrrr}
93 & 28 & 0 & 0 & 121 \\
1187 & 1255 & 0 & 0 & 2442 \\
161 & 0 & 0 & 0 & 161 \\
4 & 0 & 0 & 0 & 4 \\
791 & 0 & 0 & 0 & 791 \\
289 & 0 & 0 & 0 & 289 \\
\hline 2525 & 1283 & 0 & 0 & 3808
\end{tabular}

TARLE 79. 1977 SORGHUM RECEIFTS FROM UARIOUS ORIGINS BY FIRMS IN AREA 3602, OKLLAHOMA

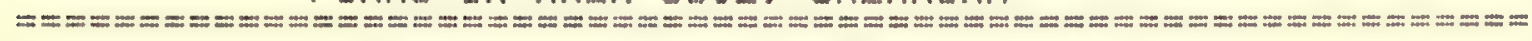

ORIGINATING
STATE OR FORT AREA

(THOUSANIS OF FUSHELS)

$\begin{array}{llrrrrr}3404 & \text { NERRASKA } & 9 & 48 & 0 & 0 & 57 \\ 3405 & \text { NEBRASKA } & 51 & 0 & 0 & 0 & 51 \\ 3502 \text { KANSAS } & 0 & 554 & 0 & 0 & 554 \\ 3503 \text { KANSAS } & 1181 & 0 & 0 & 0 & 1181 \\ 3504 & \text { KANSAS } & 1216 & 457 & 0 & 0 & 1673 \\ 3505 \text { KANSAS } & 46 & 0 & 0 & 0 & 46 \\ 3602 \text { OKLAHOMA } & 78 & 78 & 0 & 2577 & 2733 \\ \text { TOTAL VOLUME } & -1137 & 0 & 2577 & 6295\end{array}$


TAKLE $80.97 \%$ SORGHUM SHTFMENTS TO UARIOUS DESTINATIONS BY FTFMS TN AFEA 3602, OKLAHOMA

\begin{tabular}{|c|c|c|c|c|c|c|}
\hline IIESTINATION & : & MODE & OF TFF & NSFOFTAT & ION & \\
\hline STATE OR FOFT AFEA & : & FIAIL & TRUCK & : BARGE & & TOTAL \\
\hline
\end{tabular}

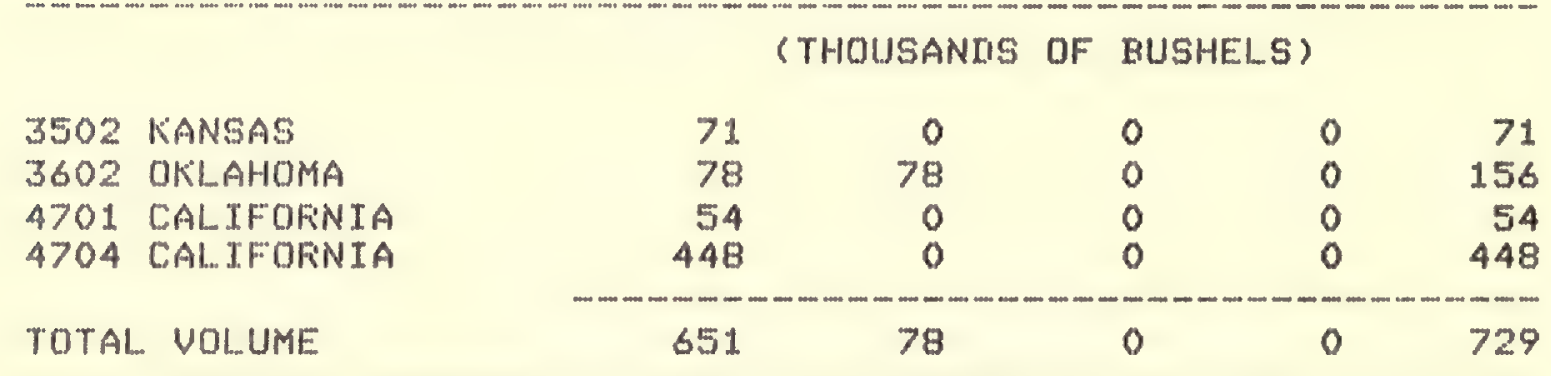

TAELE 81, 1977 SORGHUM RECEIFTS FFOM UAFIOUS OFIGINS BY FIFIS IN AFEEA 3603, OKLLAHOMA

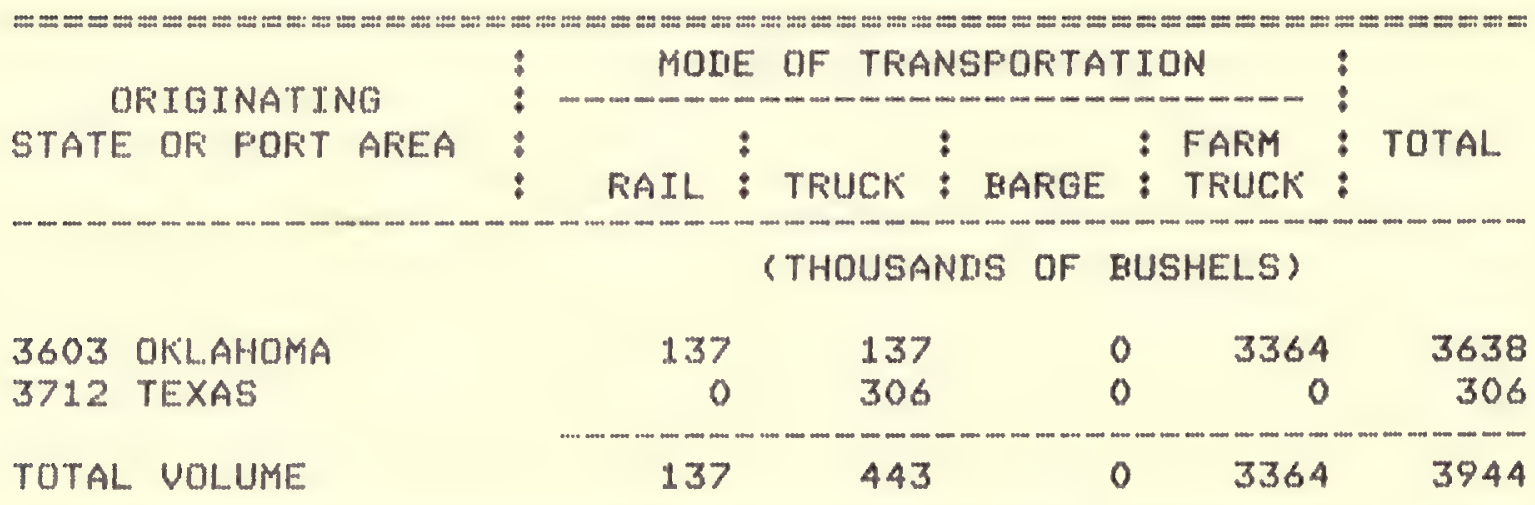

TARLE 82. 1.97\% SORGHUM SHIFMENTS TO VAFIOUS DESTINATIONS BY FIFIMS IN AFEA 3603, OKLLAHOMA

\begin{tabular}{|c|c|c|c|c|c|c|c|c|}
\hline DESTINATION & $\vdots$ & \multicolumn{2}{|c|}{ MOLIE OF } & \multicolumn{3}{|c|}{ TFANSFOFITATION } & \multirow{2}{*}{$\begin{array}{l}\vdots \\
\vdots \\
\vdots\end{array}$} & \multirow[b]{2}{*}{ TOTAL. } \\
\hline STATE OR PORT AFEA & : & RAIL & : TRUCK & : BAFGE & $\vdots$ & $\begin{array}{l}\text { FAFIM } \\
\text { TFUCK }\end{array}$ & & \\
\hline & & & \&THOUS & NIIS OF & BU & SHELS) & & \\
\hline 3603 OKLAHOMA & & 137 & 13 & & 0 & & 0 & 274 \\
\hline 3723 TEXAS & & 0 & 25 & & 0 & & 0 & 252 \\
\hline $7303 \mathrm{NO}$. TEXAS GULF & & 508 & ( & & 0 & & 0 & 508 \\
\hline TOTAL VOL...UME & & 645 & 38 & & 0 & & 0 & 1034 \\
\hline
\end{tabular}


TABLE 83. 1977 SOFGHUM FECEIFTS FFOM VAFIOUS ORIGINS BY FIFMS IN AFEA 3604 , OKLLAHOMA

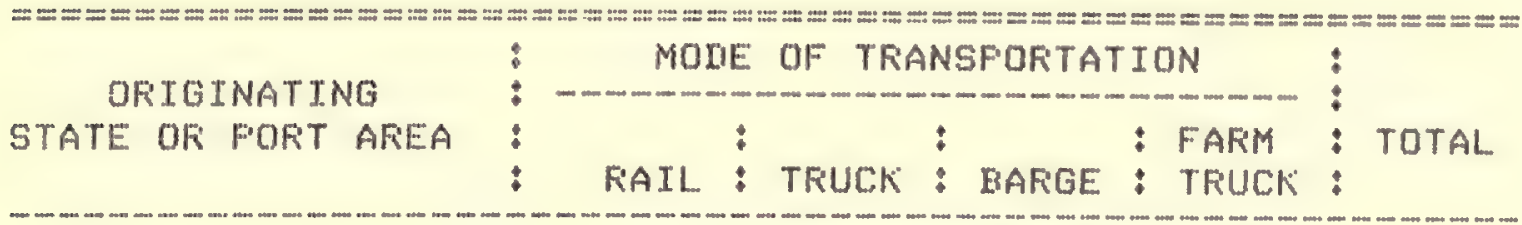

(THOUSANIIS OF EUSHELS)

\begin{tabular}{|c|c|c|c|c|c|c|}
\hline 2900 & MISSOUFI & 17 & 0 & 0 & 0 & 17 \\
\hline 3405 & NEBRASKIA & 60 & 36 & 0 & 0 & \\
\hline 3503 & KANSAS & 342 & 0 & 0 & 0 & 34 \\
\hline 3505 & KANSAS & 0 & 497 & 0 & 0 & 49 \\
\hline 3604 & OKKLAHOMA & 0 & 0 & 0 & 2719 & 271 \\
\hline TOTAL. & VOLUME & 419 & 533 & 0 & 2719 & 367 \\
\hline
\end{tabular}

TABLE 84. 1977 SORGHUM SHIFMENTS TO UARIOUS DESTINATIONS EY FIFMS IN AFEA 3604 , OKLAHOMA

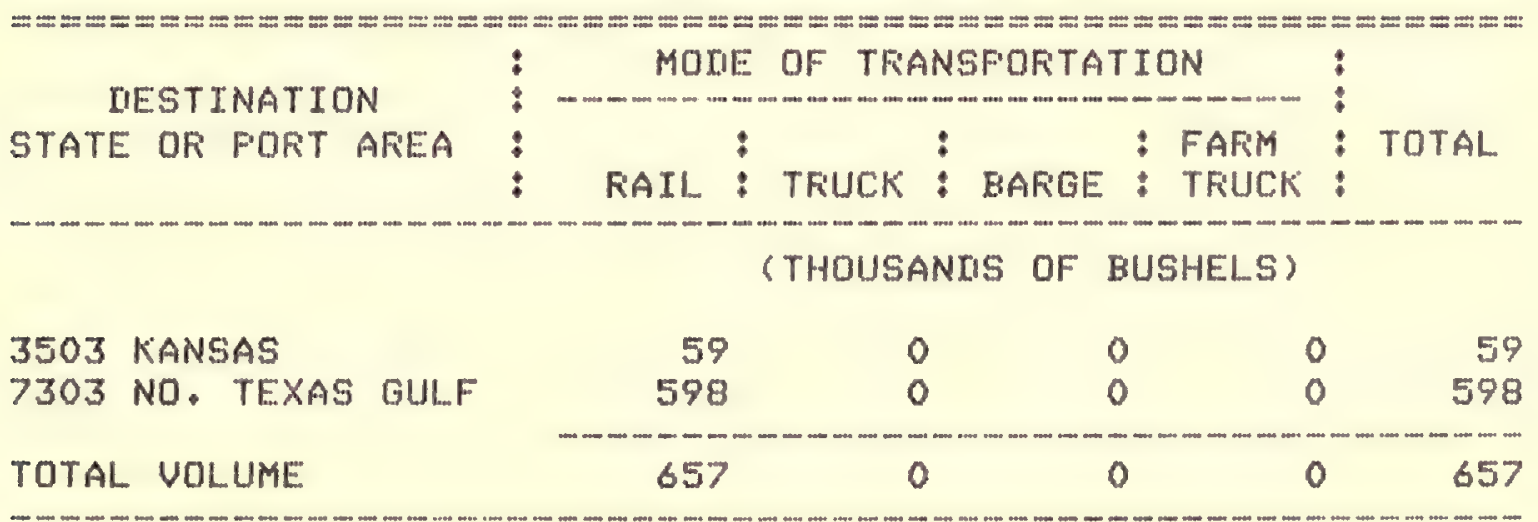

TARLE 85. 1977 SORGHUM RECEIFTS FFOM UARIOUS ORIGINS BY FIFMS IN AREA 3302, SOUTH LIAKROTA

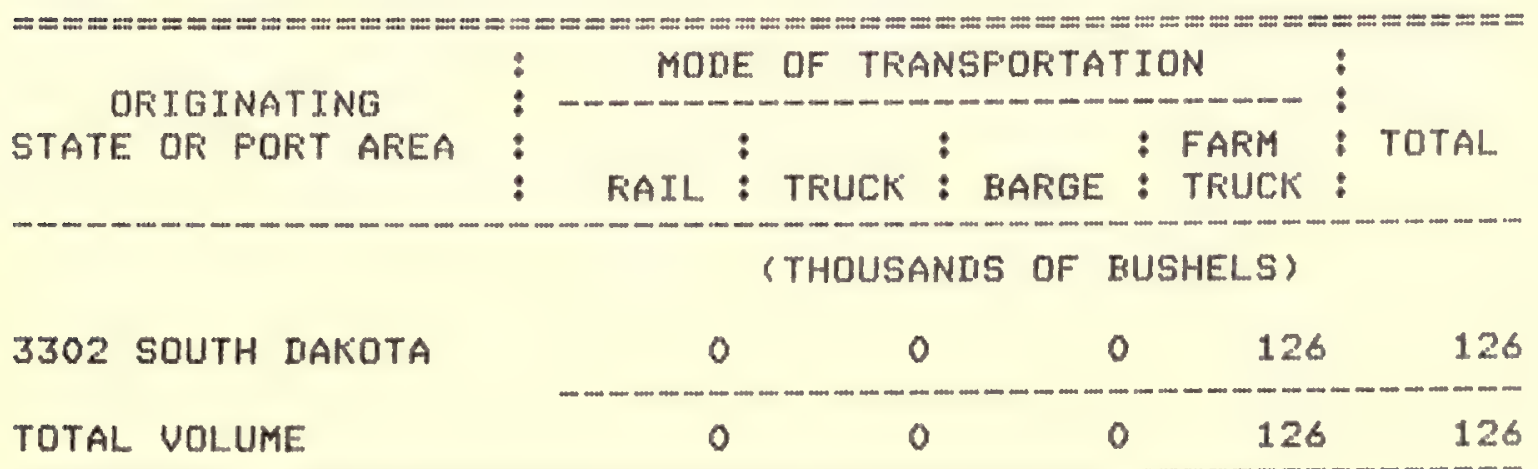


TAELE 86. 1977 SORGHUM SHIFMENTS TO VAFTOUS DESTINATTONS BY FIFMS IN AFEA 3302, SOUTH LIAKOTA

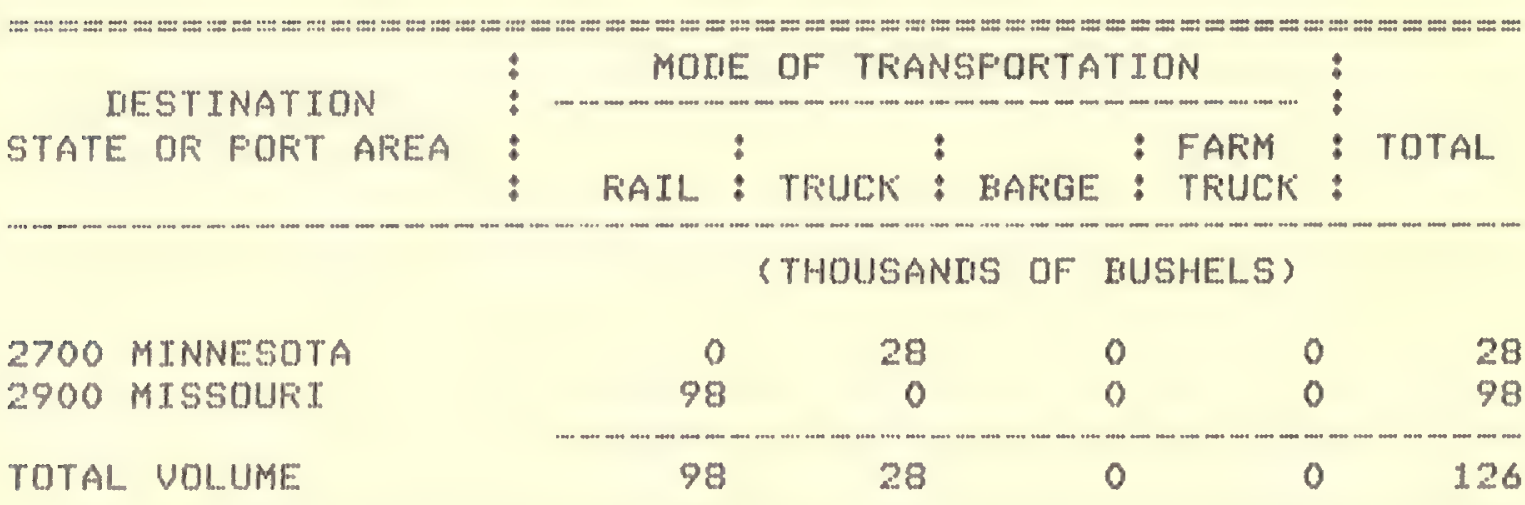

TABLE $\quad 37.1977$ SOFCHUM FECEIFTS FFOM UARIOUS ORIGINS BY FTFMS IN AFEA 2400 . TENNESSEE

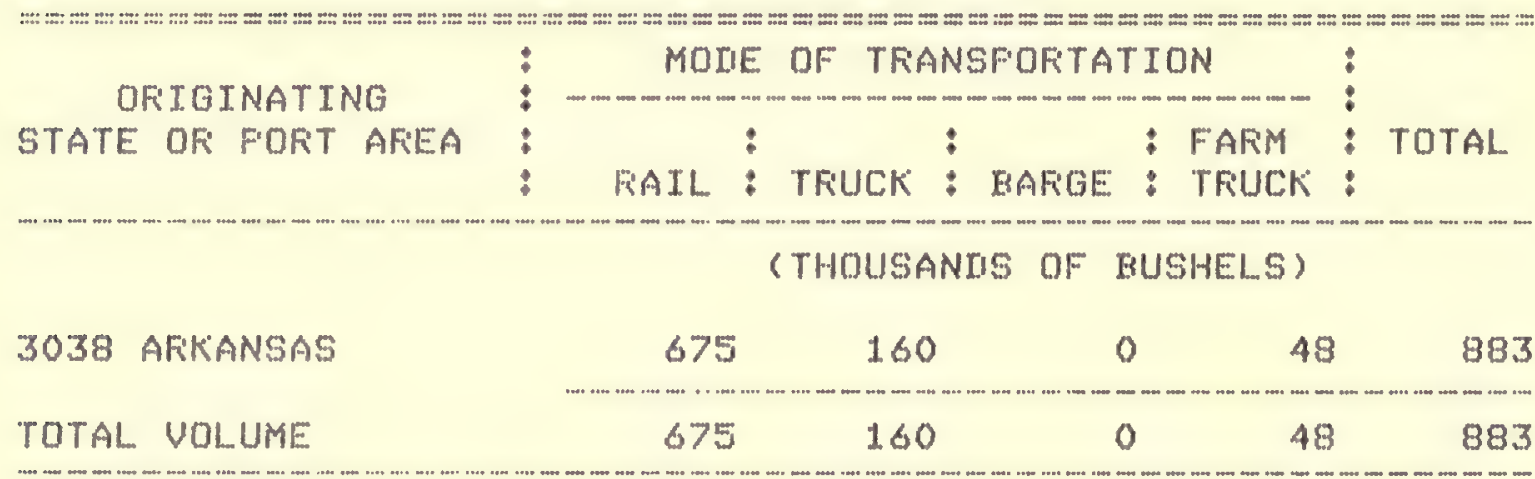

TARHE 88. 1977 SOFGHUM SHIFMENTS TO UAFIOUS IOESTINATIONS EY FIFMS IN AFEA 2AOO, TENNESSEE

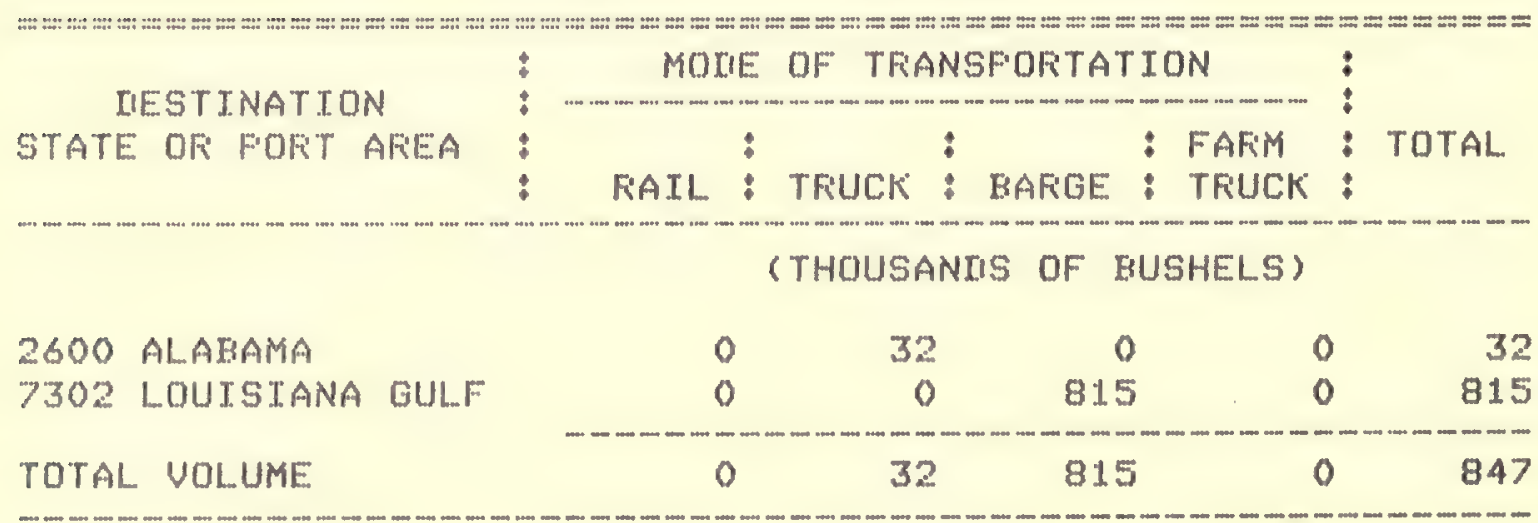


TAELE 89, 1977 SOFGHUM FECETFTS FFOM VAFIOUS ORIGINS BY FIFMS IN AREA 3710, TEXAS

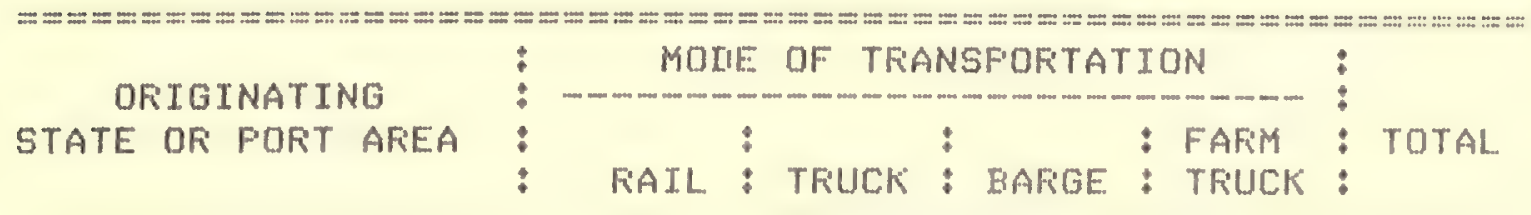

(THOUSANIIS OF BUSHELS)

$\begin{array}{ll}3710 & \text { TEXAS } \\ 3711 & \text { TEXAS } \\ 3712 & \text { TEXAS } \\ 3723 & \text { TEXAS } \\ 3745 & \text { TEXAS } \\ 3767 & \text { TEXAS } \\ 3789 & \text { TEXAS }\end{array}$

TOTAL VOLUME
$1867 \quad 2660$

$658 \quad 2292$

50

400

14

0

0

2989
2292

0

0

16

100

252

5320
- 27265

$0 \quad 0050$

0

0

0

0

0

0

0

0

50

400

30

100

$\begin{array}{ll}0 & 100 \\ 0 & 252\end{array}$

- 27265

35574

TAELE 90. 1977 SOFGHUM SHIFMENTS TO VAFIOUS DESTINATIONS EY FIFMS IN AFEA 3710, TEXAS

\begin{tabular}{|c|c|c|c|c|c|c|}
\hline INESTINATION & MOIE & \multicolumn{3}{|c|}{ TFIANSFOFTATION } & : & \multirow{3}{*}{ TOTAL. } \\
\hline STATE OF FOFTT AFEA & : & $:$ & : & : FAFiM & : & \\
\hline & FAIL & : TRUUCK & : BAFGE & : TFIUCK & : & \\
\hline & \multicolumn{5}{|c|}{ (THOUSANIIS OF BUSHELS) } & \\
\hline 3710 TEXAS & 1867 & 2660 & & 0 & 0 & 4527 \\
\hline 3767 TEXAS & 0 & 50 & & 0 & 0 & 50 \\
\hline 3789 TEXAS & 0 & 600 & & 0 & 0 & 600 \\
\hline 7304 SO. TEXAS GULF & 5811 & 5704 & & 0 & 0 & 11515 \\
\hline 9000 EXFOFT & 1884 & 0 & & 0 & 0 & 1884 \\
\hline TOTAL VOLUME & 9562 & 9014 & & 0 & 0 & 18576 \\
\hline
\end{tabular}


TAELE 91. 1977 SOFGHUM FECEIFTS FFOM UARIOUS OFIGINS BY FIFIMS IN AFEA $371 \%$ TEXAS

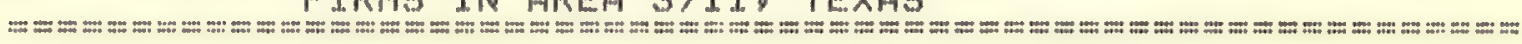

ORIGINATTNG

STATE OF FORT AFEA
MODE OF TFANSFOFTATION

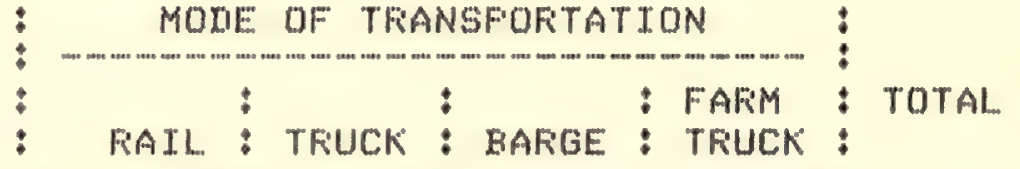

2900 MISSOURI
3404 NEBFASKA
3405 NERFASKA
3501 KANSAS
3502 KIANSAS
3503 KANSAS
3504 KANSAS
3505 KIANSAS
3601 OKLAHOMA
3711 TEXAS
3712 TEXAS
3723 TEXAS
4000 COLORAIO
4100 NEW MEXTCO
TOTAL VOLUME

2900 MISSOURI

3405 NERFIASKNA

3501 KANSAS

3502 KAANSAS

3503 K゙ANSAS

3504 KANSAS

3505 KAANSAS

3711 TEXAS

3712 TEXAS

3723 TEXAS

4000 COL... ORALIO

LUME

$\begin{array}{rrrrr}14 & 0 & 0 & 0 & 14 \\ 264 & 0 & 0 & 0 & 264 \\ 1312 & 0 & 0 & 0 & 1312 \\ 0 & 2220 & 0 & 0 & 2220 \\ 0 & 1110 & 0 & 0 & 1110 \\ 285 & 0 & 0 & 0 & 285 \\ 1274 & 1110 & 0 & 0 & 2384 \\ 933 & 0 & 0 & 0 & 933 \\ 1187 & 1255 & 0 & 0 & 2442 \\ 2358 & 37443 & 0 & 61169 & 100970 \\ 127 & 3835 & 0 & 0 & 3962 \\ 0 & 400 & 0 & 0 & 400 \\ 1355 & 258 & 0 & 0 & 1383 \\ 72 & 1844 & 0 & 0 & 1916 \\ -7181 & 49245 & 0 & 61169 & 119595\end{array}$

\section{(THOUSANIS OF EUSHELS)}

TARLE 92, 1977 SOFIGHUM SHIFMENTS TO UARIOUS IIESTINATIONS BY FIFMS IN AREA 3711 , TEXAS

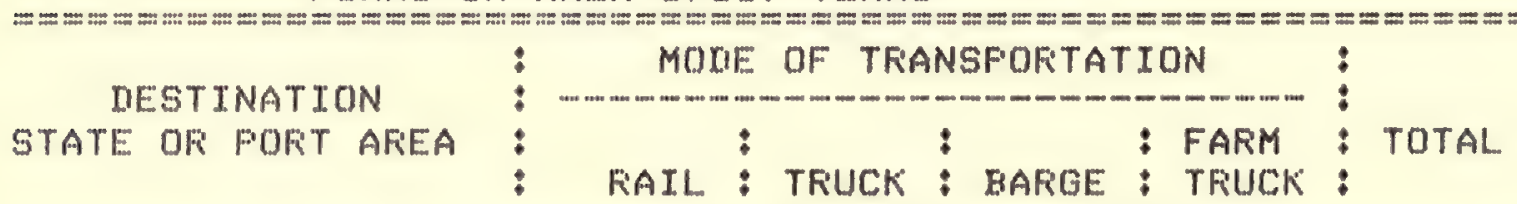

\begin{tabular}{|c|c|c|c|c|c|c|}
\hline \multirow[b]{2}{*}{3710} & \multirow[b]{2}{*}{ TEXAS } & \multicolumn{4}{|c|}{ (THOUSANDS OF BUSHELS) } & \multirow[b]{2}{*}{2950} \\
\hline & & 658 & 2292 & 0 & 0 & \\
\hline 3711 & TEXAS & 2358 & 37443 & 0 & 0 & 39801 \\
\hline $\begin{array}{l}3712 \\
3723\end{array}$ & $\begin{array}{l}\text { TEXAS } \\
\text { TEXAS }\end{array}$ & $\begin{array}{r}3495 \\
181\end{array}$ & $\begin{array}{r}755 \\
2119\end{array}$ & $\begin{array}{l}0 \\
0\end{array}$ & $\begin{array}{l}0 \\
0\end{array}$ & $\begin{array}{l}4250 \\
2300\end{array}$ \\
\hline 3745 & TEXAS & 2460 & 340 & 0 & 0 & 2800 \\
\hline 3767 & TEXAS & 8 & 1002 & 0 & 0 & 1010 \\
\hline 3789 & TEXAS & 247 & 3 & 0 & 0 & 250 \\
\hline 4300 & UTAH & 289 & 0 & 0 & 0 & 289 \\
\hline 4401 & AFIZONA & 2050 & 4 & 0 & 0 & 2054 \\
\hline 4402 & AFIZONA & 450 & 0 & 0 & 0 & 450 \\
\hline 4403 & ARIZONA & 256 & 0 & 0 & 0 & 256 \\
\hline 4704 & CALIFORNIA & 9813 & 0 & 0 & 0 & 9813 \\
\hline 7303 & NO. TEXAS GULF & 4116 & 83 & 0 & 0 & 4199 \\
\hline 7304 & S0. TEXAS GULF & 4465 & 739 & 0 & 0 & 5204 \\
\hline TOTAL & VOLUME & 30846 & 44790 & 0 & 0 & 75626 \\
\hline
\end{tabular}


TABLE 93. 1977 SORGHUM FECEIFTS FROM UARIOUS DRIGINS BY FIFIMS IN AFEA 3712 , TEXAS

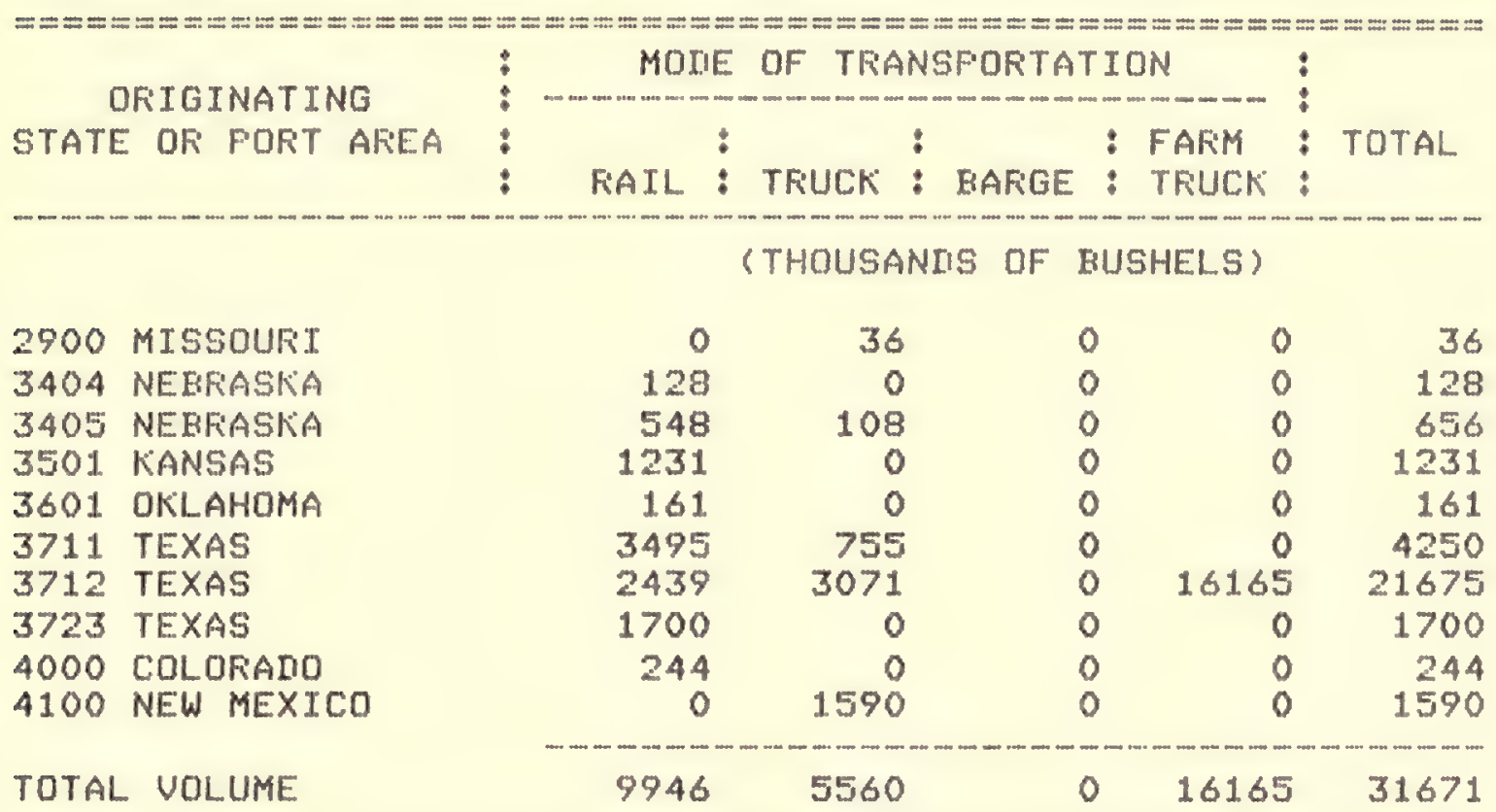

TAELE 94. 1977 SOFGHUM SHIFMENTS TO UAFIOUS DESTINATIONS BY FIFIS IN AFEA 3712, TEXAS

\begin{tabular}{|c|c|c|c|c|c|c|c|c|}
\hline IFSTTNATTON & : & MOLIE & OF TKA & NSFOFTA & IION & & ! & \\
\hline STATE OR POFT AFEA & : & FIAIL: & TRUUCK & : BARGE & $: F$ & $\begin{array}{l}\text { FAFM } \\
\text { TRUICK }\end{array}$ & : & TOTAL \\
\hline
\end{tabular}

(THOUSANIS OF BUSHELS)

\begin{tabular}{|c|c|c|c|c|c|c|}
\hline 3603 & OKLAHOMA & 0 & 306 & 0 & 0 & 306 \\
\hline 3710 & TEXAS & 50 & 0 & 0 & 0 & 50 \\
\hline 3711 & TEXAS & 127 & 3835 & 0 & 0 & 3962 \\
\hline 3712 & TEXAS & 2439 & 3071 & 0 & 0 & 5510 \\
\hline 3723 & TEXAS & 3620 & 1080 & 0 & 0 & 4700 \\
\hline $\begin{array}{l}3745 \\
3767\end{array}$ & $\begin{array}{l}\text { TEXAS } \\
\text { TEXAS }\end{array}$ & $\begin{array}{l}288 \\
345\end{array}$ & $\begin{array}{r}312 \\
7355\end{array}$ & $\begin{array}{l}0 \\
0\end{array}$ & $\begin{array}{l}0 \\
0\end{array}$ & $\begin{array}{r}600 \\
7700\end{array}$ \\
\hline 4100 & NEW MEXICO & 0 & 12 & 0 & 0 & 12 \\
\hline $\begin{array}{l}4401 \\
4402\end{array}$ & $\begin{array}{l}\text { ARI ZONA } \\
\text { ARIZONA }\end{array}$ & 0 & $\begin{array}{r}1256 \\
57\end{array}$ & 0 & 0 & 125 \\
\hline 4403 & ARIZONA & 14 & 3 & 0 & 0 & \\
\hline 4703 & CALIFOFNIA & 0 & 8 & 0 & 0 & \\
\hline 4704 & CALIFORNIA & 572 & 9 & 0 & 0 & 58 \\
\hline 7303 & NO. TEXAS GULF & 4421 & 57 & 0 & 0 & 4478 \\
\hline 7304 & SO. TEXAS GULF & 722 & 126 & 0 & 0 & 848 \\
\hline TOTAL & VOLUME & 12598 & 17482 & 0 & 0 & 30080 \\
\hline
\end{tabular}


TAELE 95. 1977 SOFGHUM FEECETFTS FFOM UAFIDUS QRIGINS BY FTFMS IN AREA 3723 , TEXAS

\begin{tabular}{|c|c|c|c|c|c|c|c|c|}
\hline \multirow{3}{*}{$\begin{array}{l}\text { OFIGINATING } \\
\text { STATE OF POFT AFEA }\end{array}$} & \multirow{3}{*}{ : } & \multicolumn{2}{|c|}{ MOIE OF } & \multicolumn{3}{|c|}{ TRANSPOFTATION } & $\vdots$ & \multirow{3}{*}{ TOTAL. } \\
\hline & & & $:$ & $:$ & : & FAFiM & : & \\
\hline & & FAIL & : TRUCK & : BAFGE & : & TRUCK & : & \\
\hline & & \multicolumn{3}{|c|}{ STHOUSANMS OF } & \multicolumn{3}{|c|}{ BUSHELS) } & \\
\hline 2900 MISSOUFI & & 1873 & 387 & & 0 & 0 & 0 & 2260 \\
\hline 301 KANSAS & & 191 & 277 & & 0 & 0 & 0 & 468 \\
\hline 3502 KANSAS & & 0 & $12 \varepsilon$ & & 0 & & 0 & 128 \\
\hline 3504 KANSSAS & & 320 & $16 \%$ & & 0 & & 0 & 482 \\
\hline 3505 KANSAS & & 311 & 0 & & 0 & & 0 & 311 \\
\hline 3603 OKKLAHOMA & & 0 & 252 & & 0 & & 0 & 252 \\
\hline 3711 TEXAS & & $18 \mathrm{~L}$ & 2119 & & 0 & & 0 & 2300 \\
\hline 3712 TEXAS & & 3620 & 1080 & & 0 & & 0 & 4700 \\
\hline 3723 TEXAS & & 154 & 7896 & & 0 & 10530 & & 18580 \\
\hline 3745 TEXAS & & 0 & 105 & & 0 & & 0 & 105 \\
\hline 3767 TEXAS & & 0 & 54 & & 0 & & 0 & 54 \\
\hline TOTAL VOLUME & & 6650 & 12460 & & 0 & 10530 & & 29640 \\
\hline
\end{tabular}

TABLE 96. 1977 SOFGHUM SHIFMENTS TO VARIOUS IESTINATIONS BY FIFIMS IN AFEA 3723, TEXAS

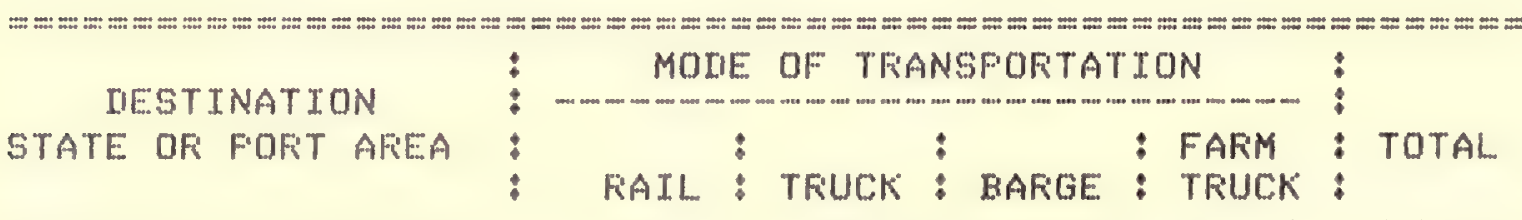

(THOUSANOS OF RUSHELS)

\begin{tabular}{|c|c|c|c|c|c|c|}
\hline 3710 & TEXAS & 400 & 0 & 0 & 0 & 400 \\
\hline 3711 & TEXAS & 0 & 400 & 0 & 0 & 400 \\
\hline 3712 & TEXAS & 1700 & 0 & 0 & 0 & 1700 \\
\hline 3723 & TEXAS & 154 & 7896 & 0 & 0 & 8050 \\
\hline 3745 & TEXAS & 40 & 460 & 0 & 0 & 500 \\
\hline 3767 & TEXAS & 0 & 100 & 0 & 0 & 100 \\
\hline 3789 & TEXAS & 0 & 150 & 0 & 0 & 150 \\
\hline 4701 & CALIFORNIA & 212 & 0 & 0 & 0 & 212 \\
\hline 7303 & NO. TEXAS GULF & 1200 & 279 & 0 & 0 & 1479 \\
\hline TOTAL & UOLUME & 3706 & 9285 & 0 & 0 & 12991 \\
\hline
\end{tabular}


TAELE 97. 1977 SOFGHUM FECETFTS FFOM UARIOUS OFIGINS BY FIFMS IN AFEA 3745 , TEXAS

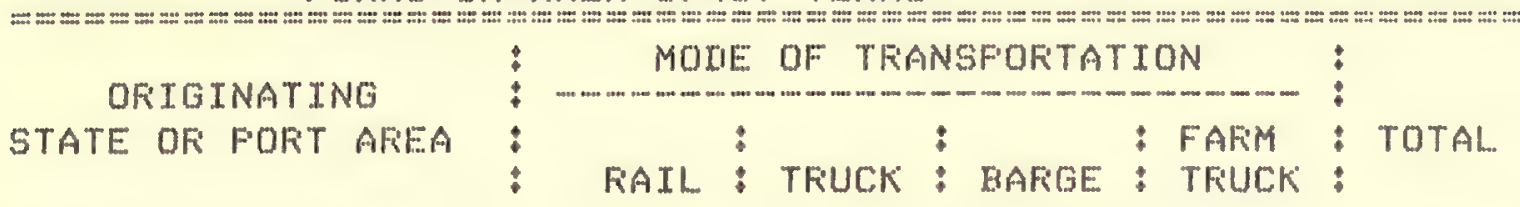

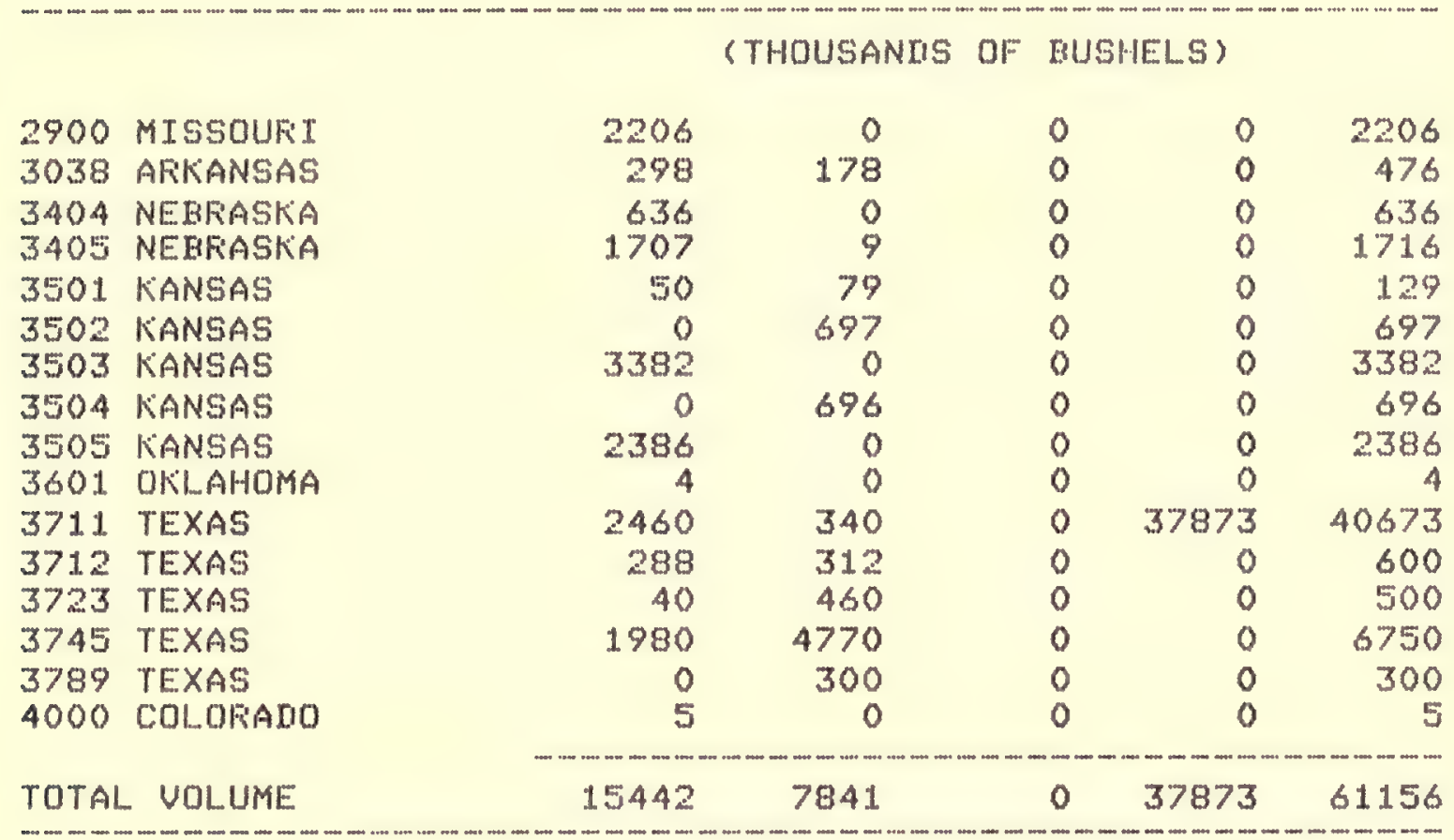

TABLE 98. 1977 SORGHUM SHIFMENTS TO VARIOUS IIESTINATIONG BY FIFMS IN AFEA 3745 , TEXAS

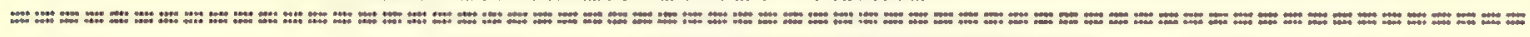

DESTINATIDN

STATE OF PORT AFEA

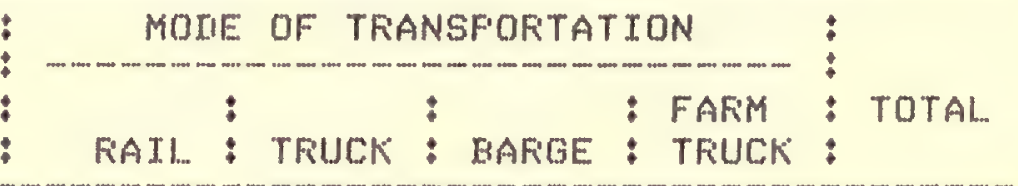

(THOUSANDIS OF BUSHELS)

\begin{tabular}{|c|c|c|c|c|c|c|}
\hline 3100 & LOUISIANA & 289 & 50 & 0 & 0 & 339 \\
\hline 3710 & TEXAS & 1.4 & 16 & 0 & 0 & 30 \\
\hline 3723 & TEXAS & 0 & 105 & 0 & 0 & 10 \\
\hline 3745 & TEXAS & 1980 & 4770 & 0 & 0 & 6750 \\
\hline 3767 & TEXAS & 0 & 60 & 0 & 0 & 60 \\
\hline 3789 & TEXAS & 230 & 1.50 & 0 & 0 & 38 \\
\hline 4401 & ARIZONA & 68 & 0 & 0 & 0 & 0 \\
\hline 4403 & AFIZONA & 12 & 0 & 0 & 0 & 1 \\
\hline 4701 & CALIFORNIA & 261 & 0 & 0 & 0 & 26 \\
\hline 4703 & CAL IFOFINIA & 15 & 0 & 0 & 0 & \\
\hline 4704 & CALIFORNIA & 22 & 0 & 0 & 0 & \\
\hline $\begin{array}{l}7303 \\
7304\end{array}$ & $\begin{array}{l}\text { ND. TEXAS GULF } \\
\text { SO. TEXAS GUL.F }\end{array}$ & $\begin{array}{r}11919 \\
440\end{array}$ & $\begin{array}{r}19585 \\
6927\end{array}$ & $\begin{array}{l}0 \\
0\end{array}$ & $\begin{array}{l}0 \\
0\end{array}$ & $\begin{array}{l}1504 \\
7367\end{array}$ \\
\hline 7403 & CALIFOFNIA & 187 & 0 & 0 & 0 & 18 \\
\hline 9000 & EXFOFT & 896 & 0 & 0 & 0 & 89 \\
\hline TOTAL & - VOLUME & 16333 & 31663 & 0 & 0 & 1799 \\
\hline
\end{tabular}


TABLE 99, 1977 SORGHUM FECETPTS FROM VARIOUS DRIGINS BY FIRMS TN AREA 3767 , TEXAS

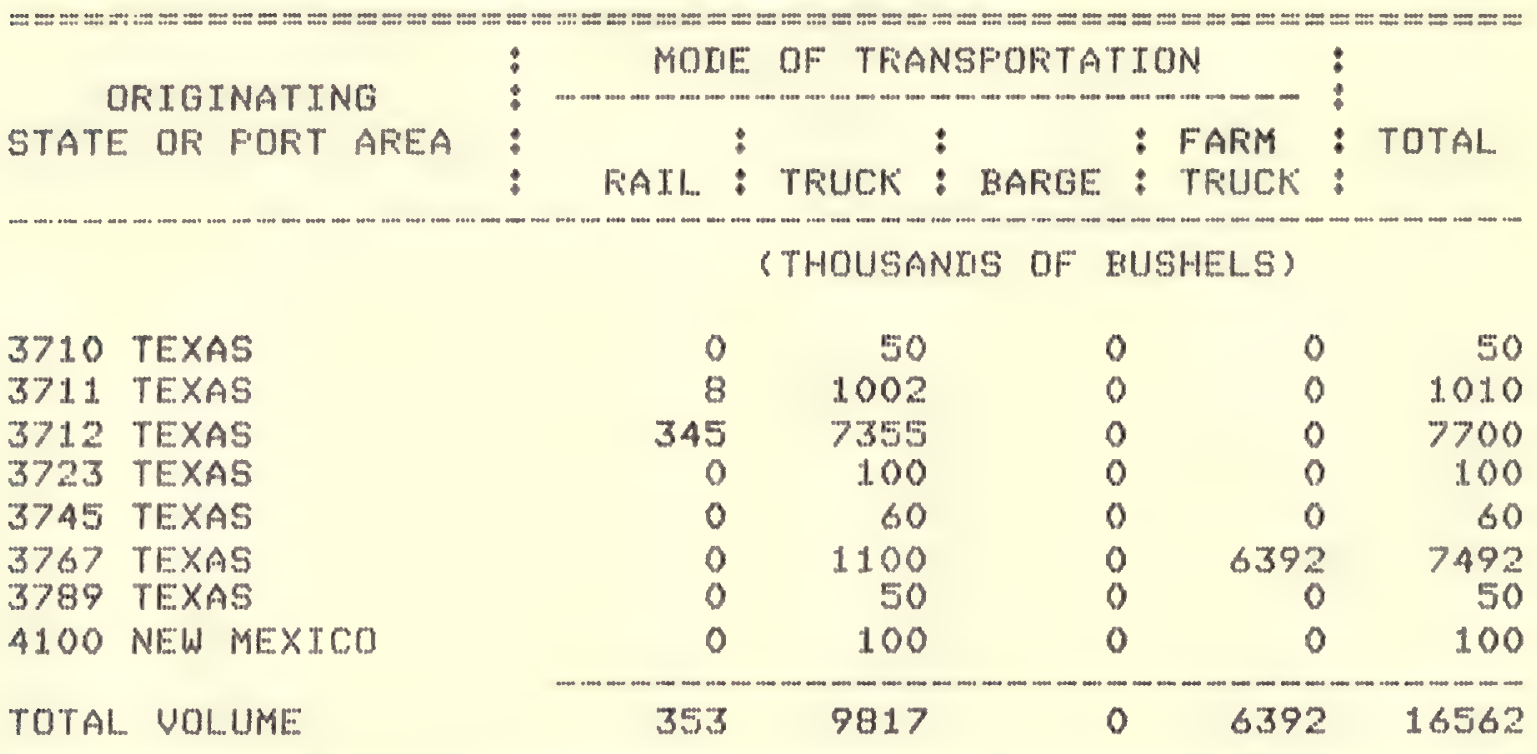

TABLE 100. 1977 SORGHUM SHIFMENTS TO VARIOUS IIESTINATIONS BY FIRMS IN AREA 3767, TEXAS

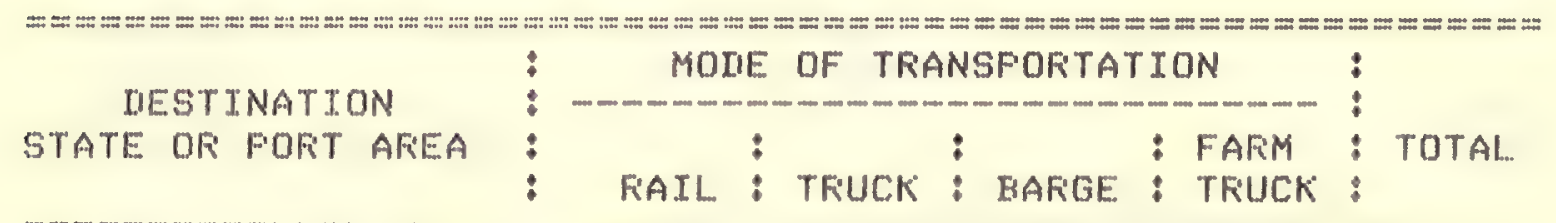

(THOUSANIS OF BUSHELS)

$\begin{array}{llrrrrr}3710 & \text { TEXAS } & 0 & 100 & 0 & 0 & 100 \\ 3723 \text { TEXAS } & 0 & 54 & 0 & 0 & 54 \\ 3767 \text { TEXAS } & 0 & 1100 & 0 & 0 & 1100 \\ 3789 \text { TEXAS } & 0 & 110 & 0 & 0 & 110 \\ 7304 \text { SO. TEXAS GULFF } & 0 & 44 & 0 & 0 & 44 \\ \text { TOTAL UOLUME } & 0 & 1408 & 0 & 0 & 1408\end{array}$


TAELE 101. 1.977 SOFGHUM FECETFTS FROM VARIOUS OFIGINS BY FTRMS TN AREA 3789, TEXAS

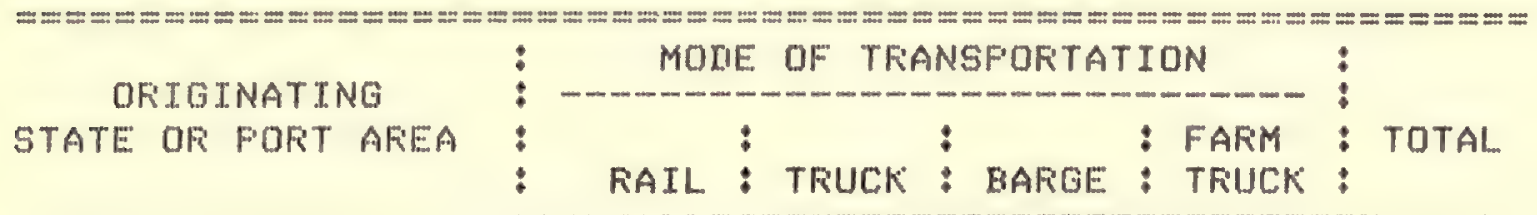

(THOUSANAS DF EUSHELS)

3504 KANSAS

3505 KANSAS

3710 TEXAS

3711 TEXAS

3723 TEXAS

3745 TEXAS

3767 TEXAS

3789 TEXAS

TOTAL VOLUME
151

159

0

247

0

230

0

0

138
0
600
3
150
150
110
5250

00

$0-158$

$0 \quad 0600$

$0 \quad 0 \quad 250$

$0 \quad 0 \quad 150$

$0 \quad 0 \quad 380$

$\begin{array}{lll}0 & 0 & 380\end{array}$

0 $71458 \quad 76708$

787

6401

- 71458

78646

TAELE 102. 1977 SORGHUM SHIFMENTS TO VARIOUS DESTINATIONS BY FIFMS IN AFEA 3789 , TEXAS

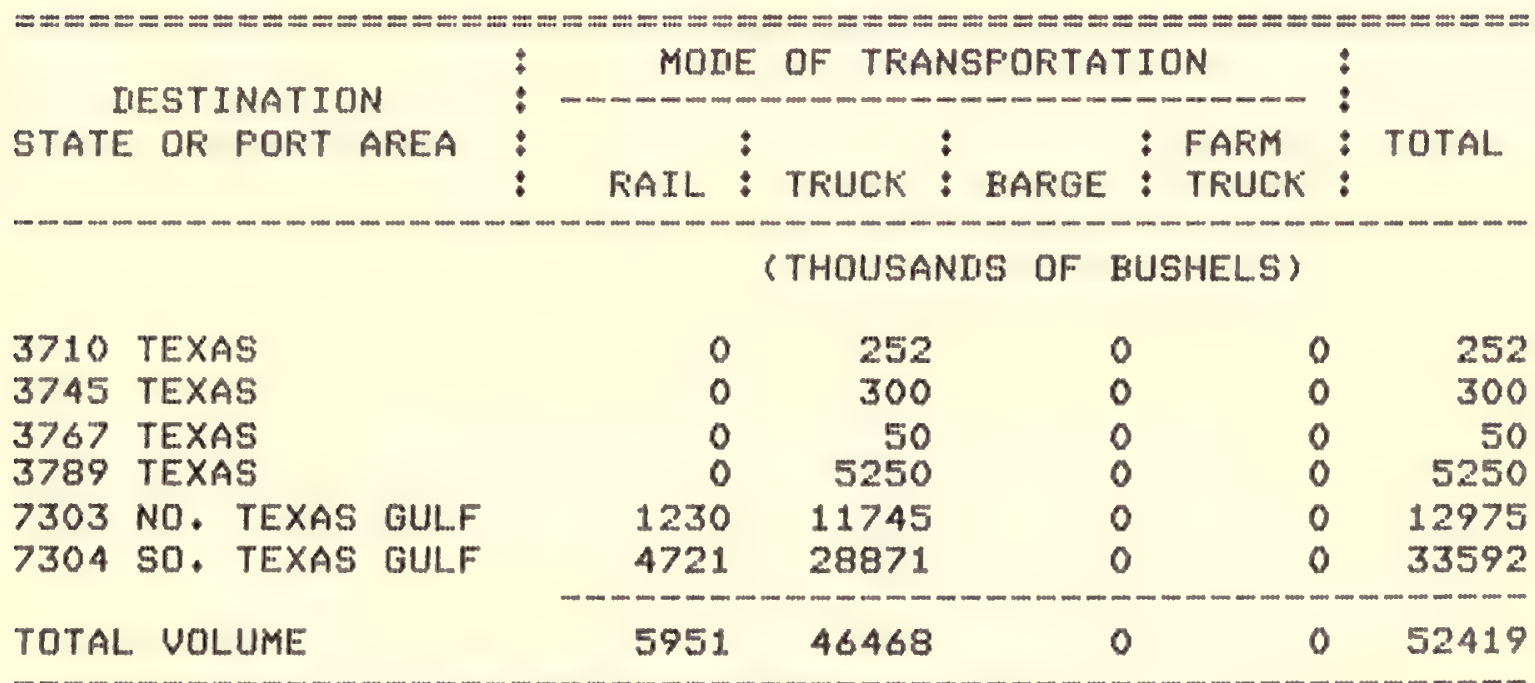


TABLE 103, 1977 SOFGHUM FECEIFTS FFOM UAFIOUS OFIGINS BY FIFIMS IN AFEA 4300, UTAH

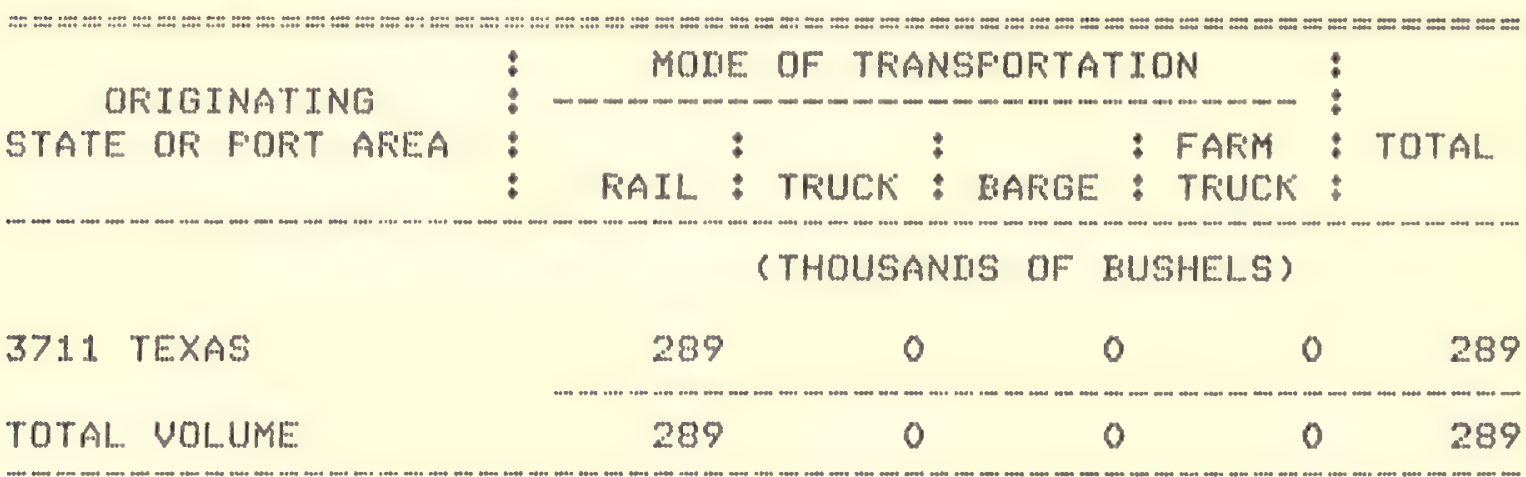

TAEHE 104. 1977 SOFGHUM FECEIFTS FFOM VAFIOUS DFIGINS BY FIFIS IN AFEA 7302, LOUISIANA GULF

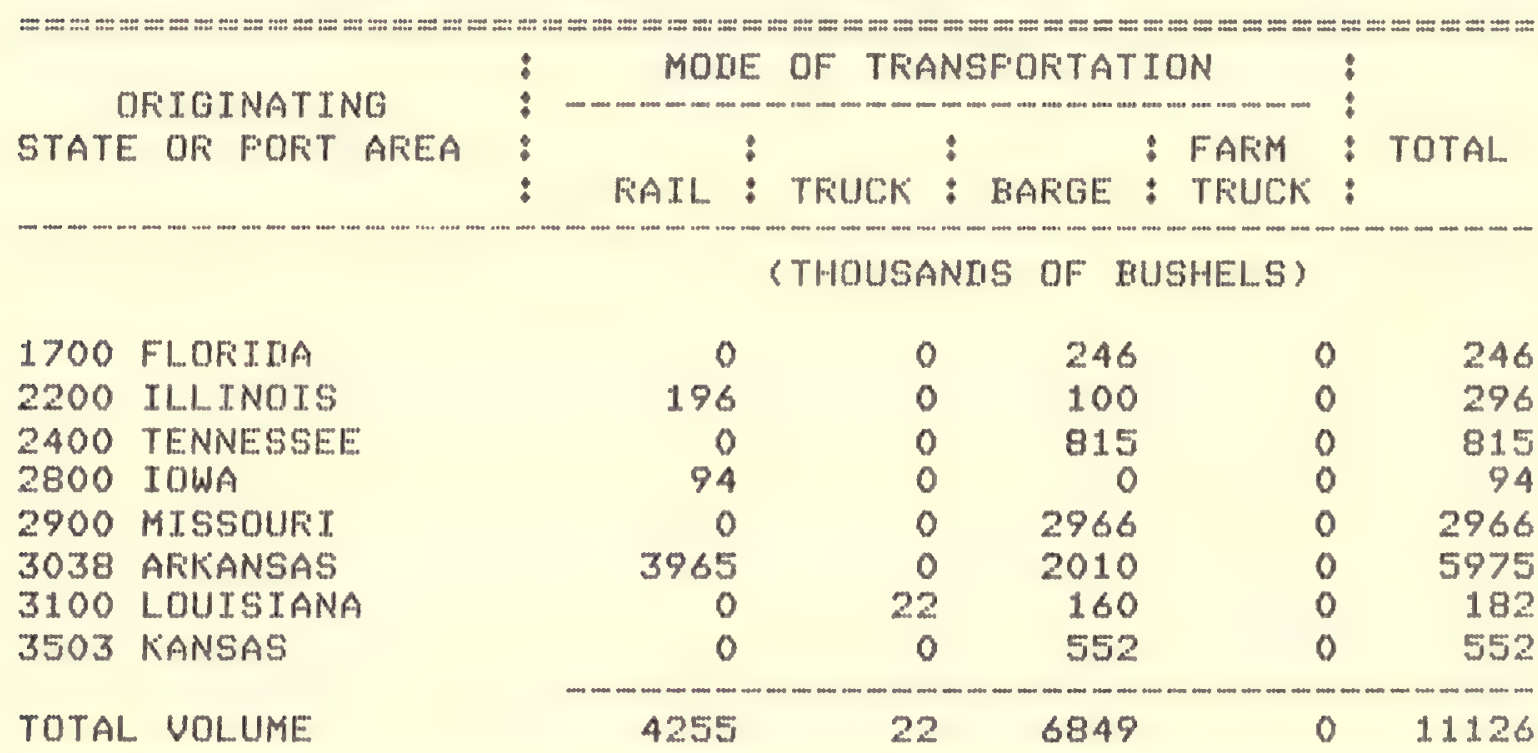

TAELE 105. 1977 SOFGHUM SHIFMENTS TO VAFIOUS DESTINATIONS BY FIFIMS IN AFEA 7302, LOUISIANA GULF

\begin{tabular}{|c|c|c|c|c|c|c|}
\hline DESTINATION & : & MOIIE & OF TFiA & NSFOFTAT & ION & \\
\hline STATE OR FUFIT AFEA & : & FIAIL: & TFUUKK & : BAFIGE & & TOTAL \\
\hline
\end{tabular}

(THOUSANIS OF EUSHELS)

\begin{tabular}{|c|c|c|c|c|c|}
\hline 3100 LDUISIANA & 0 & 22 & 0 & 0 & 22 \\
\hline 9000 EXFOFT & 0 & 0 & 7854 & 0 & 7854 \\
\hline TOTAL VOLUME & 0 & 22 & 7854 & 0 & 787 \\
\hline
\end{tabular}


TAELE 106. 1977 SOFGHUM RECEIFTS FROM UARIOUS ORIGINS BY FIFIMS IN AFEA 7303, NO. TEXAS GULF

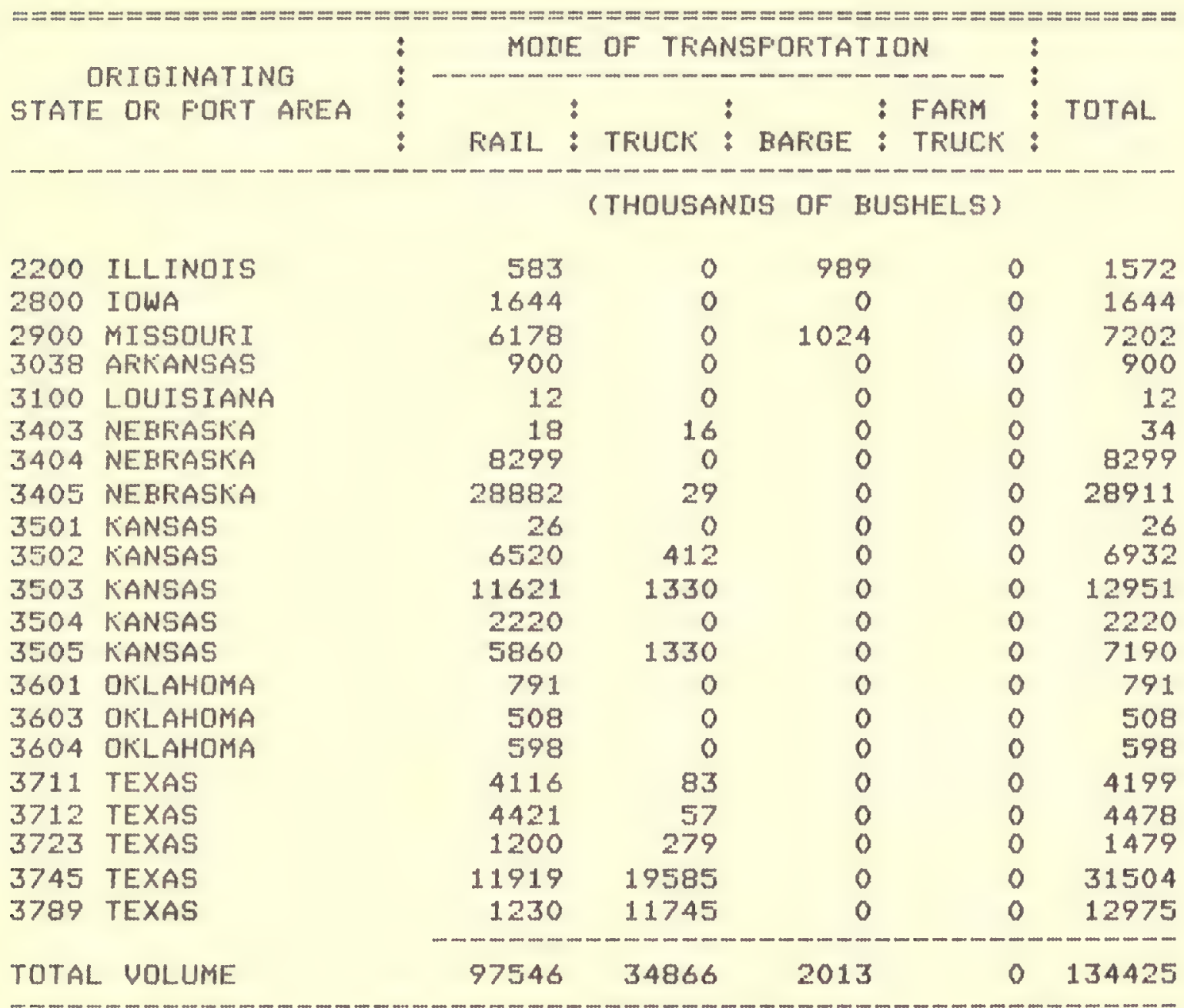

TABLE 107. 1977 SOFGHUM SHIFMENTS TO UARIOUS IIESTINATIONS BY FIFMS IN AREA 7303, NO. TEXAS GULF

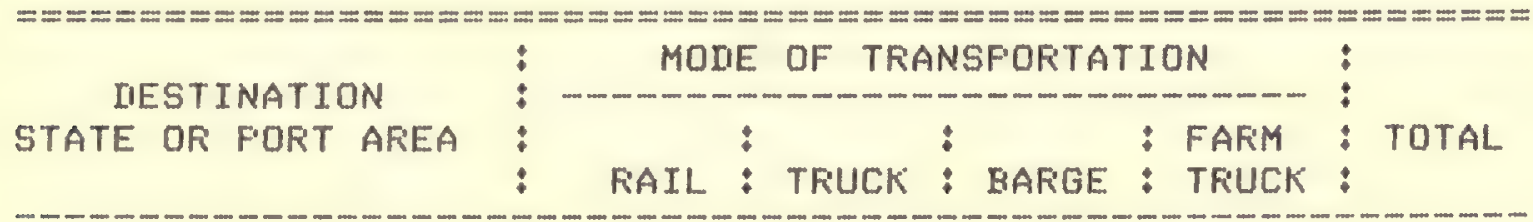

(THOUSANIIS OF BUSHELS)

9000 EXFOFT

$0 \quad 0 \quad 132010 \quad 0 \quad 132010$

TOTAL VOLUME

0

- 132010

- 132010 
TAELE 108. 1977 SORGHUM RECEIPTS FROM UARIOUS ORIGINS BY FIFMS IN AREA 7304, SO. TEXAS GULF

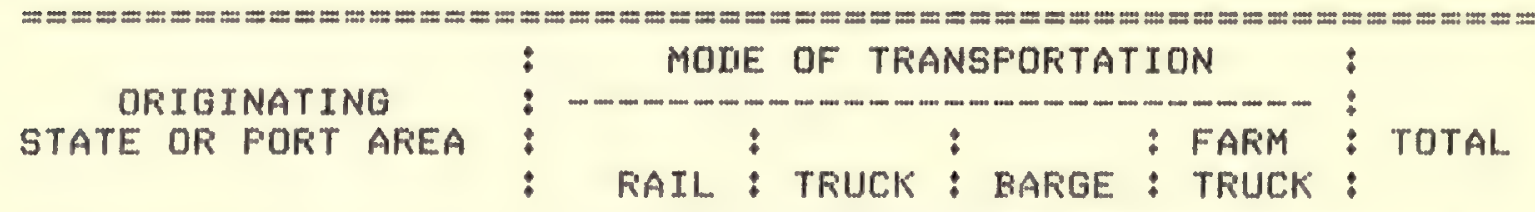

\begin{tabular}{|c|c|c|c|c|c|c|}
\hline \multirow[b]{2}{*}{2200} & \multirow[b]{2}{*}{ ILL TNOTS } & \multicolumn{3}{|c|}{ (THOUSANDIS OF } & EUSHELS) & \multirow[b]{2}{*}{349} \\
\hline & & 349 & 0 & 0 & 0 & \\
\hline 2800 & IOWA & 203 & 0 & 0 & 0 & 203 \\
\hline 2900 & MISSOUFI & 4336 & 13 & 0 & 0 & 4349 \\
\hline 3404 & NEBFIASKA & 1679 & 0 & 0 & 0 & 1679 \\
\hline 3405 & NEEFIASKKA & 14901 & 0 & 0 & 0 & 14901 \\
\hline 3502 & KANSAS & 987 & 0 & 0 & 0 & 987 \\
\hline 3503 & KANSAS & 7468 & 21 & 0 & 0 & 7489 \\
\hline 3504 & KANSAS & 1577 & 0 & 0 & 0 & 1577 \\
\hline 3505 & KANSAS & 2670 & 21 & 0 & 0 & 2691 \\
\hline 3601 & DKKLAHDMA & 289 & 0 & 0 & 0 & 289 \\
\hline 3710 & TEXAS & 5811 & 5704 & 0 & 0 & 11515 \\
\hline 3711 & TEXAS & 4465 & 739 & 0 & 0 & 5204 \\
\hline 3712 & TEXAS & 722 & 126 & 0 & 0 & 848 \\
\hline 3745 & TEXAS & 440 & 6927 & 0 & 0 & 7367 \\
\hline 3767 & TEXAS & 0 & 44 & 0 & 0 & 44 \\
\hline 3789 & TEXAS & 4721 & 28871 & 0 & 0 & 33592 \\
\hline 4100 & NEW MEXICO & 122 & 0 & 0 & 0 & 122 \\
\hline 4401 & AFIIZONA & 94 & 0 & 0 & 0 & 94 \\
\hline TOTAL & VOLUME & 50834 & 42466 & 0 & 0 & 93300 \\
\hline
\end{tabular}

TAELE 109. 1977 SOFGHUM SHIPMENTS TO VAFIOUS IIESTINATIONS BY FIFMS IN AFEA 7304, SO. TEXAS GULF

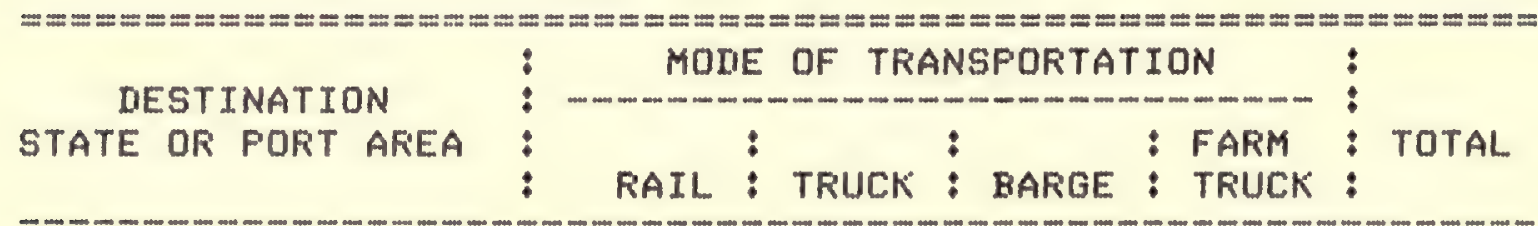

(THOUSANDS OF BUSHELS)

9000 EXFORT

\begin{tabular}{ccccc}
0 & 0 & 91100 & 0 & 91100 \\
\hline 0 & 0 & 91100 & 0 & 91100
\end{tabular}

TOTAL VOLUME 
TAELE 110, 1977 SOFGHUM FECETFTS FFOM UARTOUS ORIGINS BY FIFMS IN AREA 7401, COLUMRIA RIUER

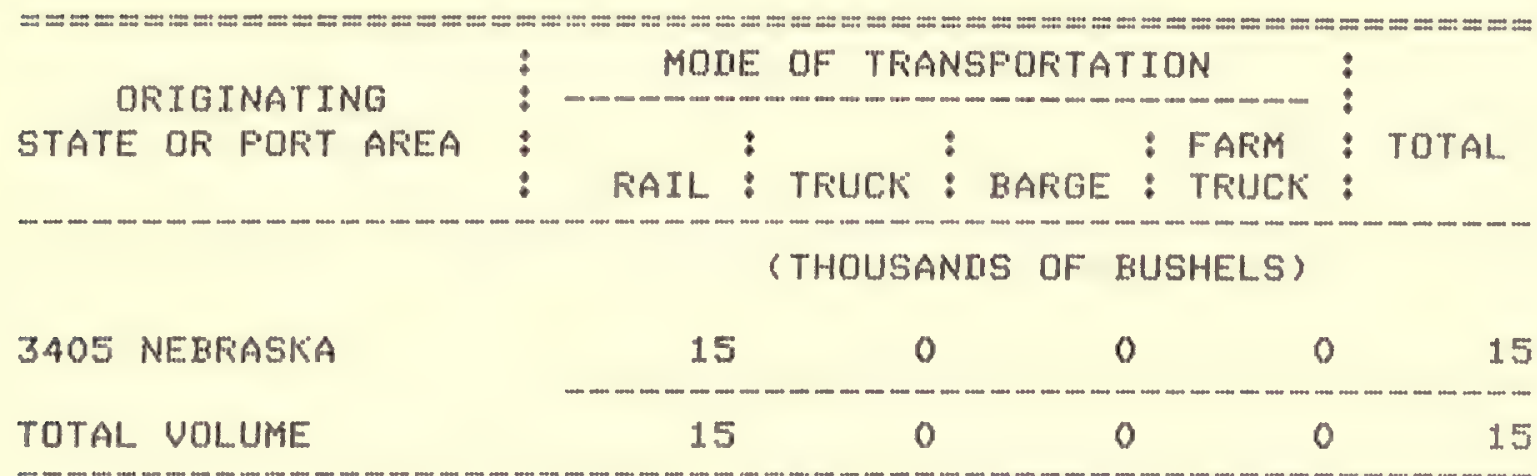

TAELE 111. 1977 SORGHUM SHIFMENTS TO VAFIOUS IESTINATIONS BY FIFMS IN AFEA 7401, COL..UMBIA FITUEF

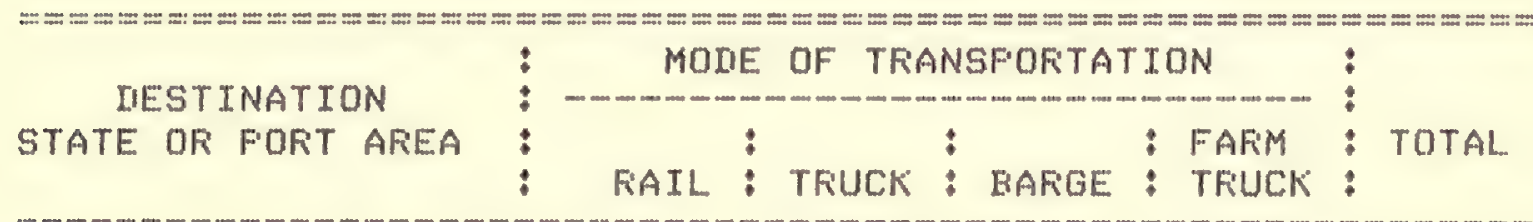

(THOUSANIS OF BUSHELS)

$\begin{array}{lccccc}9000 \text { EXPORT } & 0 & 0 & 15 & 0 & 15 \\ \text { TOTAL VOLUME } & 0 & 0 & 15 & 0 & 15\end{array}$

TABLE 112. 1977 SOFGHUM FECEIFTS FFOM UAFIOUS OFIGINS BY FIFIMS IN AFEA 7402, FUGET SOUNI

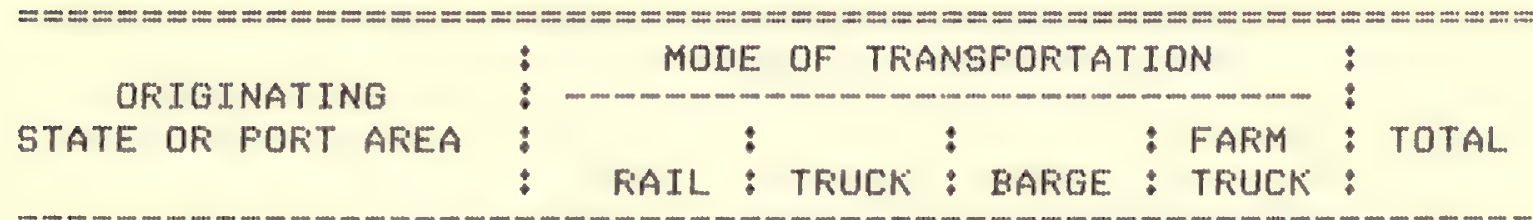

(THOUSANIIS OF BUSHELS)

$\begin{array}{lccccrr}2900 & \text { MISSOURI } & 172 & 0 & 0 & 0 & 172 \\ 3038 \text { ARKANSAS } & 0 & 1865 & 0 & 0 & 1865 \\ 3404 \text { NERRASKA } & 89 & 0 & 0 & 0 & 89 \\ 3405 \text { NERRASKA } & 70 & 0 & 0 & 0 & 70 \\ \text { TOTAL UOLUME } & 331 & 1865 & 0 & 0 & 2196\end{array}$


TARLE 113. 1977 SORGHUM SHIFMENTS TO UARIOUS DESTINATIONS EY FIFIS IN AFEA 7402, FUGET SOUND

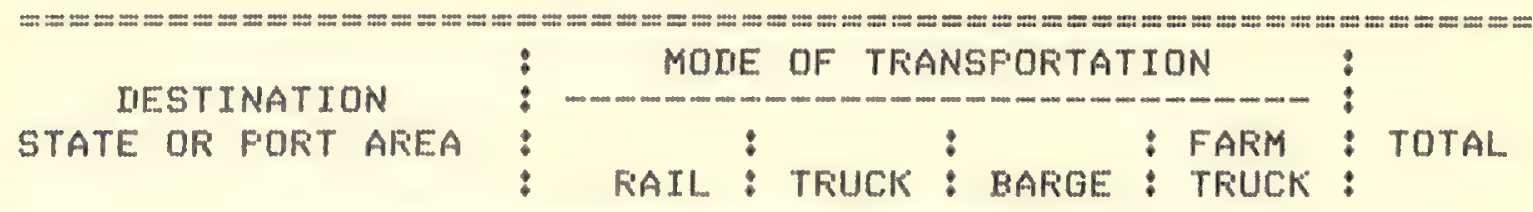

(THOUSANIS OF BUSHELS)

9000 EXFORT

TOTAL VOLUME

\begin{tabular}{ccccr}
0 & 0 & 1641 & 0 & 1641 \\
\hline 0 & 0 & 1641 & 0 & 1641
\end{tabular}

TARLE 114, 1977 SORGHUM RECEIFTS FROM VARIOUS ORIGINS BY FIRMS IN AREA 7403, CALIFORNIA

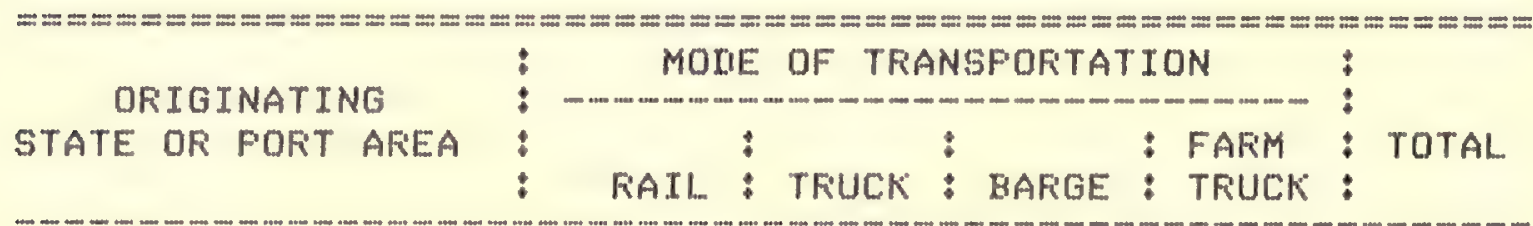

3404 NEERASKIA

3405 NEHRASKKA

3502 KANSAS

3504 KANSAS

3505 KANSAS

3745 TEXAS

4703 CALIFOFNIA

TOTAL VOLUME
(THOUSANIS OF RUSHELS)

$\begin{array}{rrrrr}65 & 0 & 0 & 0 & 65 \\ 1046 & 0 & 0 & 0 & 1046 \\ 68 & 0 & 0 & 0 & 68 \\ 24 & 0 & 0 & 0 & 24 \\ 149 & 0 & 0 & 0 & 149 \\ 187 & 0 & 0 & 0 & 187 \\ 0 & 0 & 0 & 626 & 626 \\ 1539 & 0 & 0 & 626 & 2165\end{array}$

TABLE 115. 1977 SOFGHUM SHIFMENTS TO UARIOUS DESTINATIONS BY FIFIS IN AFEA 7403, CALIFOFNIA

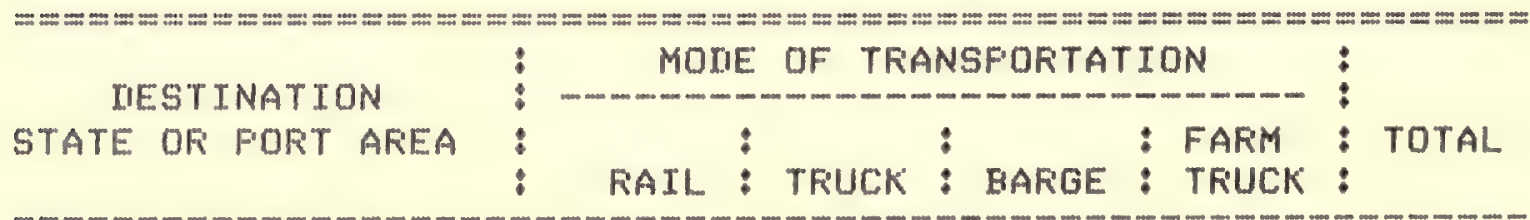

(THOUSANMS OF EUSHELS)

9000 EXFORT

TOTAL VOLUME

$\begin{array}{ccccc}0 & 0 & 1919 & 0 & 1919 \\ 0 & 0 & 1919 & 0 & 1919\end{array}$






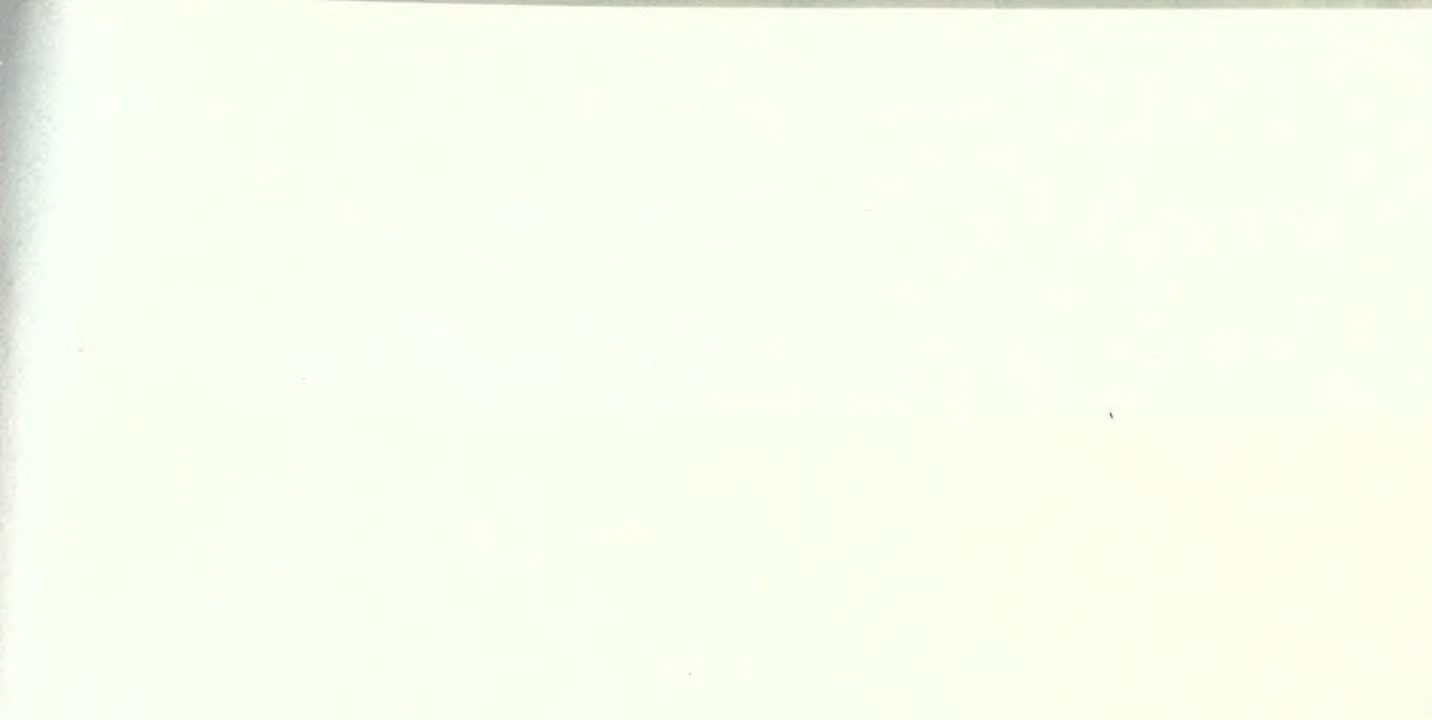

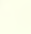


UNIVERSITY OF ILLINOIS-URBANA

0.630.71.68

BULLETIN. URBANA C008

30112019531174 